\title{
Skull osteology of Aetosauroides scagliai Casamiquela, 1960 (Archosauria: Aetosauria) from the Late Triassic of Brazil: New insights into the paleobiology of aetosaurs
}

\author{
Voltaire Dutra Paes Neto, Julia Brenda Desojo, Ana Carolina Biacchi Brust, \\ Ana Maria Ribeiro, Cesar Leandro Schultz, and Marina Bento Soares
}

\begin{abstract}
Aetosauroides scagliai, from the Ischigualasto Formation of Argentina and Santa Maria Supersequence of Brazil (Carnian-Norian), is one of the oldest members of Aetosauria, a diverse clade of armored crocodile-line archosaurs. Aetosauroides scagliai differs from other aetosaurs in having the maxilla excluded from the margin of the external nares, the length/width ratio of the postzygapophyses $\leq 0.75$, and other features that place it as one of the earliest-diverging members of the clade. In this paper we provide a detailed description of the skull of $A$. scagliai based on a new Brazilian specimen, revealing that it lacks a pneumatic cavity on the medial surface of the maxilla and further differs from all other known aetosaurs by the presence of $\geq 12$ dentary teeth. However, contra previous studies, the elongated posterior process of the jugal does articulate ventrally with the quadratojugal in $A$. scagliai, forming the posteroventral corner of the skull as in all other aetosaurs. Aetosauroides scagliai exhibits some characters typical of predatory archosaurs (like the recurved ziphodont teeth and mandibular articulation at the level of the tooth row), but was probably an omnivore, as it also shares several probable adaptations for herbivory with aetosaurs generally (i.e., edentulous anterior premaxilla and dentary) and stagonolepidoids specifically (e.g., shovel-shaped snout). This suggests that there was greater trophic diversity in this clade than usually recognized, at least early in their evolutionary history.
\end{abstract}

Voltaire Dutra Paes Neto. Programa de Pós-Graduação em Geociências. Av. Bento Gonçalves 9500, Prédio 43127, 91540-000, Porto Alegre, Brazil. voltairearts@gmail.com

Julia Brenda Desojo. División Paleontología Vertebrados, Museo de La Plata, Paseo del Bosque s $/ n^{\circ}$, La Plata, B1900FWA, Buenos Aires, Argentina; Consejo Nacional de Investigaciones Científicas y Tecnológicas (CONICET). julideso@fcnym.unlp.edu.ar Ana Carolina Biacchi Brust. Centro de Estudos e Pesquisas em Direito e Internet. Av. Roraima, 1000, 74B (3427), 97105-900, Santa Maria, Brazil. anacarolinabrust@gmail.com Ana Maria Ribeiro. Museu de Ciências Naturais do Rio Grande do Sul - SEMA/RS. Dr. Salvador França, 1427 - Jardim Botânico, Porto Alegre - RS, 90690-000 amaria_ribeiro@yahoo.com.br

Paes Neto, Voltaire Dutra, Desojo, Julia Brenda, Brust, Ana Carolina Biacchi, Ribeiro, Ana Maria, Schultz, Cesar Leandro and Soares, Marina Bento. 2021. Skull osteology of Aetosauroides scagliai Casamiquela, 1960 (Archosauria: Aetosauria) from the Late Triassic of Brazil: New insights into the paleobiology of aetosaurs. Palaeontologia Electronica, 24(3):a33. https://doi.org/10.26879/1120

palaeo-electronica.org/content/2021/3463-aetosauroides-skull

Copyright: September 2021 Paleontological Society.

This is an open access article distributed under the terms of Attribution-NonCommercial-ShareAlike 4.0 International (CC BY-NC-SA 4.0 ), which permits users to copy and redistribute the material in any medium or format, provided it is not used for commercial purposes and the original author and source are credited, with indications if any changes are made.

creativecommons.org/licenses/by-nc-sa/4.0/ 
Cesar Leandro Schultz. Programa de Pós-Graduação em Geociências. Av. Bento Gonçalves 9500, Prédio 43127, 91540-000, Porto Alegre, Brazil. cesar.schultz@ufrgs.br

Marina Bento Soares. Museu Nacional, Universidade Federal do Rio de Janeiro. Parque da Quinta da Boa vista s/n 20940-040, Rio de Janeiro, RJ, Brazil. marina.soares@mn.ufrj.br

Keywords: cranial osteology; Reptilia; teeth; Gondwana; paleoecology

Submission: 17 August 2020. Acceptance: 8 September 2021.

\section{INTRODUCTION}

Aetosauria is a clade of quadrupedal, armored archosaurs in the crocodile stem-lineage (variously called Pseudosuchia or Crurotarsi), which are restricted to the Late Triassic and were nearly cosmopolitan in distribution (Desojo et al., 2013). Although there is consensus about their monophyly, their phylogenetic position relative to other pseudosuchians is still debatable. Recent discoveries indicate that the historically poorly-known taxon Revueltosaurus Hunt, 1989 (and its possible relatives Acaenasuchus and Euscolosuchus), from the Carnian-Norian of the United States, represents the sister-taxon of Aetosauria (Nesbitt, 2011; Nesbitt et al., 2017; Marsh et al., 2020). However, the relationship between this Revueltosaurus-aetosaur clade and others on the crocodilian stem remains poorly resolved. Early cladistic studies tended to recover aetosaurs as closely related to Crocodylomorpha (Parrish, 1994; Gower and Walker, 1996; Brusatte et al., 2010), but more recent analyses generally recover this clade either near the base of Pseudosuchia (Nesbitt, 2011; Butler et al., 2014; Ezcurra, 2016; Lacerda et al., 2018; Desojo et al., 2020b; Foffa et al., 2020) or as part of a larger clade with the enigmatic erpetosuchids (Ezcurra et al., 2017; Nesbitt et al., 2017; Müller et al., 2020; Marsh et al., 2020).

The oldest undisputed aetosaurs come from the coeval upper Carnian units of South America (Desojo and Ezcurra, 2011; Desojo et al., 2012; Parker, 2016a), with Aetosauroides scagliai Casamiquela, 1960 recovered from both the Ischigualasto Formation of Argentina and Santa Maria Supersequence of Brazil. In Brazil, two other Carnian species were previously recognized, each based on single occurrences: Aetobarbakinoides brasiliensis Desojo et al., 2012 and 'Polesinesuchus aurelioi' Roberto-da-Silva et al., 2014. However, the latter species was recently reinterpreted as a junior synonym of $A$. scagliai, with apparent differences being attributable to the immature state of the holotype (Paes Neto et al., 2021b). In phylogenetic analyses, $A$. scagliai has been recovered as either the sister-taxon of Stagonolepis robertsoni Agassiz, 1844 (e.g., Parrish, 1994; Heckert et al., 1996; Heckert and Lucas, 1999; Harris et al., 2003; Parker, 2007) or as the earliest-diverging aetosaur (i.e., the only non-stagonolepidid aetosaur; e.g., Desojo et al., 2012; Heckert et al., 2015; Schoch and Desojo, 2016; Parker, 2016a; Brust et al., 2018; Hoffman et al., 2018; Reyes et al., 2021). Recent research on $A$. scagliai has provided a better understanding of its intraspecific variation (Desojo and Ezcurra, 2011; Taborda et al., 2013; Taborda et al., 2015; Paes Neto et al., 2021b) and cranial osteology (Brust et al., 2018; Paes Neto et al., 2021a). These and other studies (e.g., Desojo, 2005) have firmly established the Gondwanan $A$. scagliai as a valid taxon, distinct from the Laurasian S. robertsoni and Calyptosuchus wellesi Long and Ballew, 1985 (contra Heckert and Lucas, 2000; Lucas and Heckert, 2001; Heckert and Lucas, 2002), a status recognized in most recent work on the group (e.g., Desojo et al., 2012, 2013; Robertoda-Silva et al., 2014; Heckert et al., 2015; Parker, 2016a,b; Schoch and Desojo, 2016; Ezcurra et al., 2017; Brust et al., 2018; Hoffman et al., 2018; Parker, 2018a,b; Desojo et al., 2020a,b; Marsh et al., 2020; Czepiński et al., 2021; Reyes et al., 2021).

Despite recent research attention, several characters of taxonomic interest remain unknown or poorly understood in the skull of Aetosauroides scagliai. Here we describe for the first time the morphology of the posterior portion of the skull and mandible of $A$. scagliai, with a detailed description of previously unknown cranial elements (i.e., jugal, quadratojugal, postorbital, squamosal, angular, articular, and prearticular) and the internal surface of the premaxilla, maxilla, and prefrontal, based on a new Brazilian specimen (MCN-PV 2347). We also compare this specimen with other aetosaurs and selected pseudosuchian outgroups. Furthermore, we provide considerations regarding feeding strategies in A. scagliai, based on its dental pattern and assorted rostral and mandibular characters, 
with implications for the evolution of dietary patterns in Aetosauria as a whole.

\section{Institutional Abbreviations}

CPEZ, Museu Arqueológico e Paleontológico Walter Ilha, São Pedro do Sul, Brazil; DMNH, Denver Museum of Nature and Science, Denver, USA; ELGNM, Elgin Museum, Elgin, Scotland; GPIT, Institut und Museum für Geologie und Paläeontologie, Eberhard Karls Universität Tübingen, Tübingen, Germany; MCN, Museu de Ciências Naturais, Secretaria Estadual do Meio Ambiente e Infraestrutura, Porto Alegre, Brazil; MCP, Museu de Ciências e Tecnologia da Pontifícia Universidade Católica do Rio Grande do Sul, Porto Alegre, Brazil; MCZ, Museum of Comparative Zoology, Harvard University, Cambridge, USA; MCZD, Marischal College Zoology Department, University of Aberdeen, Aberdeen, Scotland; MMACR, Museum Municipal Aristides Carlos Rodrigues, Candelária, Brazil; MNA, Museum of Northern Arizona, Flagstaff, USA; NCSM, North Carolina Museum of Natural Sciences, Raleigh, USA; NMS, National Museum of Scotland, Edinburgh, Scotland; NHMUK, The Natural History Museum, London, England; NMMNH, New Mexico Museum of Natural History and Science, Albuquerque, USA; PEFO, Petrified Forest National Park, Petrified Forest, USA; PULR, Paleontología, Museo de Ciencias Naturales, Universidad Nacional de La Rioja, La Rioja, Argentina; PVL, Paleontología de Vertebrados, Instituto 'Miguel Lillo', San Miguel de Tucumán, Argentina; PVSJ, División de Paleontología de Vertebrados del Museo de Ciencias Naturales y Universidad Nacional de San Juan, San Juan, Argentina; SMNS, Staatliches Museum für Naturkunde, Stuttgart, Germany; TMM, Texas Memorial Museum, Austin, USA; TTUP, Museum of Texas Tech, Lubbock, USA; UCMP, University of California Museum of Paleontology, Berkeley, USA; UFRGS-PV, Paleontologia de Vertebrados, Universidade Federal do Rio Grande do Sul, Porto Alegre, Brazil; UFSM, Laboratório de Estratigrafia e Paleobiologia, Universidade Federal de Santa Maria, Santa Maria, Brazil; ULBRAPV-T, Universidade Luterana do Brasil, Canoas, Brazil; UMMP, University of Michigan Museum of Paleontology, Ann Arbor, USA; USNM, National Museum of Natural History, Smithsonian Institution, Washington, D.C., USA; YPM, Peabody Museum of Natural History, Yale University, New Haven, USA; ZPAL, Institute of Paleobiology of the Polish Academy of Sciences, Warsaw, Poland.

\section{GEOLOGICAL SETTING}

The vertebrate record of the Upper Triassic of South America has yielded a remarkably rich terrestrial faunal content, providing an important window into the early evolutionary history of the major archosaurian lineages (Langer et al., 2007; Martinez et al., 2012; Cabreira et al., 2016; Pretto et al., 2018; Müller et al., 2018; Ezcurra et al., 2017; Mastrantonio et al., 2019; Desojo et al., 2020a; Schultz et al., 2020). In Brazil, aetosaurs come from outcrops located in the state of Rio Grande do Sul (Figure 1A), assigned by sequence stratigraphy to the base of the Candelária Sequence, Santa Maria Supersequence (sensu Horn et al., 2014), and by biostratigraphy to the Hyperodapedon Assemblage Zone (HAZ; e.g., Lucas and Heckert, 2001; Desojo and Ezcurra, 2011; Langer et al., 2007; Leal and Da-Rosa, 2009; Schultz et al., 2020). Brazilian specimens of Aetosauroides scagliai have been recovered from three HAZ outcrops named Inhamandá, Faixa Nova, and Buriol, whose layers are composed of laminated reddish mudstones, fine massive sandstones, or stratified sandstones with ripple marks representing sheet deltas and ephemeral lakes (Horn et al., 2014; Schultz et al., 2020). The specimen reported here, MCN-PV 2347 (Figure 1D), was recovered from the mudstone layers of the Piche Site (the same as Outcrop 1 of Perez and Malabarba, 2002) on the fringes of São João do Polêsine city (Figure 1B, C and E). The faunal composition of the Piche Site supports its correlation with other outcrops of the HAZ (Langer et al., 2007; Desojo et al., 2012; Roberto da Silva et al., 2013; Jenisch et al., 2017; Garcia et al., 2019; Schultz et al., 2020).

The holotype of Aetosauroides scagliai and several referred specimens come from the lower layers of the Ischigualasto Formation, in the Cancha de Bochas Member, associated with the Scaphonyx-Exaeretodon-Herrerasaurus Biozone (SEHB; e.g., Casamiquela, 1960, 1961, 1967; Heckert and Lucas, 2002; Desojo and Ezcurra, 2011; Martinez et al. 2012; Taborda et al., 2015; Desojo et al., 2020b). A few additional specimens are known from the younger strata of the Exaeretodon Biozone (Martinez et al., 2012). The SEHB and the HAZ are considered biostratigraphically equivalent based on their common faunal elements (e.g., Langer et al., 2007; Martinez et al., 2012; Langer et al., 2018 Desojo et al., 2020b; Schultz et al., 2020) and have been confirmed at ages around 229.25 and 233.23 Ma through radioisotopic dating (e.g., Martinez et al., 2012; Langer et al., 2018; Desojo et al., 2020b). 


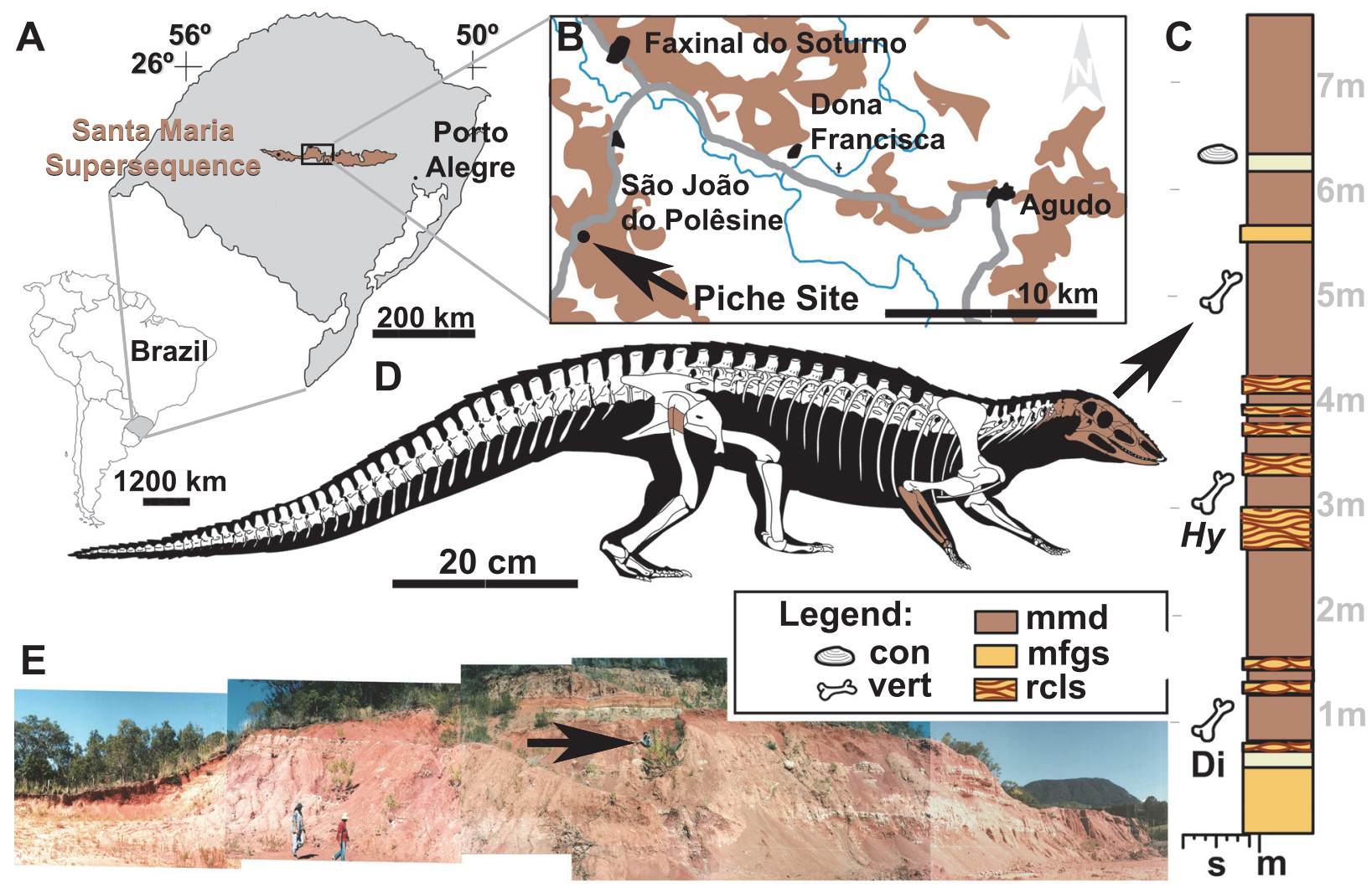

FIGURE 1. The Aetosauroides scagliai specimen MCN-PV 2347 and the location of the study area. A, map of the Santa Maria Supersequence in the Rio Grande do Sul state, southern Brazil (modified from Jenisch et al., 2017). B, map of the São João do Polêsine area, with the Candelária Sequence exposures highlighted (brown), showing the location (arrow) of the Piche Site outcrop (modified from Müller et al., 2018). C, stratigraphic column of the Piche Site (modified from Jenisch et al., 2017), with position of MCN-PV 2347 indicated (arrow). D, reconstruction of MCN-PV 2347 with preserved elements in brown. E, panoramic view of the Piche Site with the collection point of MCN-PV 2347 indicated by the arrow. Abbreviations: con, conchostracan remains; Di, dinosaur remains; Hy, Hyperodapedon remains; mmd, massive mudstone; mfgs, massive fine-grained sand; rcl, ripple cross-laminated sandstone; vert, vertebrate remains.

\section{MATERIAL AND METHODS}

A detailed description of the skull of the new Aetosauroides scagliai specimen MCN-PV 2347 is provided herein. We compare this specimen with other A. scagliai skulls (MCP-3450-PV, PVL 2052, PVL 2059, UFSM 11505, and ULBRAPV003T), and also with other selected pseudosuchian material (i.e., aetosaurs, erpetosuchids, gracilisuchids, and loricatans) through first-hand observations by the authors and based on the primary literature (see Table 1). A revision of the osteology of the right parietal of the immature $A$. scagliai specimen ULBRAPV003T (type material of 'Polesinesuchus aurelioi'), described previously by Roberto-da-Silva et al. (2013), is also presented here, as well as the description of an unpublished jugal. Also, we figure and describe, for the first time, the fragmentary skull of MCP-3450-PV, which presents overlapping elements with MCN-PV 2347, but was never described in detail (see Lucas and Heckert, 2001).

The jugal of ULBRAPV003T and the skull elements of MCN-PV 2347 and MCP-3450-PV were prepared manually with air scribes (Microjack 1 and 2; PaleoTools) and needles. Consolidants Paraloid B-72, polyethylene glycol, and ethyl cyanoacrylate-based resins were used when needed. Three skull fragments of MCN-PV 2347 were scanned using a Bruker SkyScan 1173 microtomograph (source voltage of $130 \mathrm{kV}$ and current of 61 $\mathrm{uA}$ ) at the Instituto de Petróleo e dos Recursos Naturais (Laboratório de Sedimentologia e Petrologia) of Pontifícia Universidade Católica do Rio Grande do Sul (PUCRS). The slices were segmented manually with Avizo 7.1 using the interpolate tool between slices of $29 \mu \mathrm{m}$ thickness. 
TABLE 1. List of comparative taxa used in this study. Type-materials are indicated in bold.

\begin{tabular}{|c|c|c|}
\hline Taxa & Primary Reference & $\begin{array}{l}\text { Specimens studied in } \\
\text { first-hand by V.D.P.N. }\end{array}$ \\
\hline Aetobarbakinoides brasiliensis & Desojo et al., 2012. & CPEZ-168. \\
\hline Aetosauroides scagliai & $\begin{array}{l}\text { Casamiquela, 1960; 1961; 1967; Desojo, 2005; } \\
\text { Desojo and Ezcurra, 2011; Brust et al., } 2018 .\end{array}$ & $\begin{array}{l}\text { PVL 2052; PVL 2059; MCN-PV 2347; } \\
\text { MCP-3450-PV; UFSM } 11505 .\end{array}$ \\
\hline cf. Aetosauroides scagliai & Desojo, 2005; Parker, 2016a. & PVSJ 326. \\
\hline Aetosaurus ferratus & Walker, 1961; Schoch, 2007. & $\begin{array}{l}\text { SMNS } 5770 \text {, mainly S-16, S-18 and S- } \\
21 \text {; SMNS } 18554 \text {. }\end{array}$ \\
\hline cf. Aetosaurus ferratus & Jenkins et al., 1994. & MCZ 9479R cast of MCZ 22/92G. \\
\hline Acaenasuchus geoffroyi & Marsh et al., 2020. & \\
\hline Archaeopelta arborensis & Desojo et al., 2011. & CPEZ-239a \\
\hline Caiman latirostris & - & UFRGS-PV-002-Z. \\
\hline Calyptosuchus wellesi & Long and Murry, 1995; Parker, 2018. & $\begin{array}{l}\text { UMMP 13950. Putative materials are } \\
\text { UCMP } 27409 \text {, UCMP } 27414 \text {, UCMP } \\
78695 \text { and UCMP } 195192 .\end{array}$ \\
\hline Coahomasuchus chathamensis & Heckert et al., 2017; Hoffman et al., 2018, 2019. & NCSM 23618. \\
\hline Coahomasuchus kahleorum & $\begin{array}{l}\text { Heckert and Lucas, 1999; Desojo and Heckert, } \\
2004 .\end{array}$ & NMMNH P-18496. \\
\hline Desmatosuchus smalli & Small, 2002; Parker, 2005. & $\begin{array}{l}\text { TTU-P 9023; TTU-P 9024; TTU-P } \\
\text { 9025; TTU-P 9420; }\end{array}$ \\
\hline Desmatosuchus spurensis & $\begin{array}{l}\text { Case, 1922; Long and Murry, 1995; Parker, 2005; } \\
\text { Parker, 2008; Parker, } 2018 .\end{array}$ & $\begin{array}{l}\text { GPIT-PV-108053; UCMP 25877; UCMP } \\
\text { 27988; UCMP 34490*; UMMP 3396*; } \\
\text { UMMP V7476 and MNA V } 9300 .\end{array}$ \\
\hline Diandongosuchus fuyuanensis & Stocker et al., 2017. & \\
\hline Dyoplax arenaceus & Maisch et al., 2013. & SMNS 4760 \\
\hline Dromicosuchus grallator & Sues et al., 2003. & NCSM 13733 (previous UCN 15574). \\
\hline Effigia okeeffeae & Nesbitt, 2007. & AMNH 30587. \\
\hline Erpetosuchus granti & Benton and Walker 2002. & - \\
\hline Erpetosuchus sp. & Olsen et al., 2001. & AMNH FR 29300. \\
\hline Hesperosuchus gracilis & Nesbitt, 2011. & AMNH FR 6758. \\
\hline Gracilisuchus stipanicicorum & Romer, 1972; Lecuona, 2013; Butler et al., 2014. & PULR 08, MCZ 4116 and MCZ 4117. \\
\hline Longosuchus meadei & Sawin, 1947; Witmer, 1997; Nesbitt, 2011. & TMM 31185-97; TMM 31185-98. \\
\hline Lucasuchus hunti & Parker, 2016a. & $\begin{array}{l}\text { TMM 31100-531*, TMM 31100-1 and } \\
\text { TMM 31100-313. }\end{array}$ \\
\hline Mandasuchus tanyauchen & Butler et al., 2017. & - \\
\hline Neoaetosauroides engaeus & $\begin{array}{l}\text { Bonaparte, 1969; Desojo, 2005; Desojo and } \\
\text { Báez, } 2007 .\end{array}$ & PVL 3525 and PULR 5698. \\
\hline Ornithosuchus woodwardi & Walker, 1964; von Baczko and Ezcurra, 2016. & - \\
\hline Pagosvenator candelariensis & Lacerda et al., 2018. & MMACR PV 036-T \\
\hline Paratypothorax andressorum & Schoch and Desojo, 2016. & SMNS 19003. \\
\hline Paratypothorax sp. & Long and Ballew, 1985; Parker, 2016a. & PEFO 3004 and TTU-P09416. \\
\hline Parringtonia gracilis & Nesbitt and Butler, 2013; Nesbitt et al., 2018. & - \\
\hline Polesinesuchus aurelioi & Roberto-da-Silva et al., 2013 & ULBRAPV003T. \\
\hline Prestosuchus chiniquensis & $\begin{array}{l}\text { Mastrantonio et al., 2013; Mastrantonio et al., } \\
2019 .\end{array}$ & UFRGS-PV-0629-T. \\
\hline Revueltosaurus callenderi & Parker et al., 2005; Nesbitt, 2011. & - \\
\hline Riojasuchus tenuisceps & von Baczko et al. 2016. & PVL 3827 (by J.B.D.). \\
\hline Scutarx deltatylus & Parker, 2016b. & PEFO 34616. \\
\hline
\end{tabular}


TABLE 1 (continued).

\begin{tabular}{|c|c|c|}
\hline Taxa & Primary Reference & $\begin{array}{l}\text { Specimens studied in } \\
\text { first-hand by V.D.P.N. }\end{array}$ \\
\hline Stagonolepis robertsoni & $\begin{array}{l}\text { Walker, 1961; Witmer, 1997; Gower and Walker, } \\
2002 .\end{array}$ & $\begin{array}{l}\text { ELGNM 38; MCZD 2; and several NSM } \\
\text { casts, including R } 4790 \text { and R } 4787 \text {. }\end{array}$ \\
\hline Stagonolepis olenkae & Sulej, 2010. & $\begin{array}{l}\text { ZPAL AbIII/466/17; ZPAL AbIII/1996 } \\
\text { and ZPAL AblII/1997; ZPAL AbIII/2000; } \\
\text { ZPAL AbIII/2376; ZPAL AbIII/2722; and } \\
\text { ZPAL AbIII 50124. }\end{array}$ \\
\hline Stenomyti huangae & Small and Martz, 2013. & $\begin{array}{l}\text { DMNH 34565; DMNH 60708; } \\
\text { DMNH } 61392 \text {. Putative specimens are } \\
\text { DMNH } 55070 \text { and DMNH } 45882 .\end{array}$ \\
\hline Stegomus arcuatus & Lucas et al., 1998. & YPM [PU] 21759; YPM-PU 21750. \\
\hline Tarjadia ruthae & $\begin{array}{l}\text { Arcucci and Marscicano, 1998; Ezcurra et al. } \\
2017 .\end{array}$ & PULR 63. \\
\hline Typothorax coccinarum & $\begin{array}{l}\text { Martz, 2002; Heckert and Lucas, 2010; Reyes et } \\
\text { al. } 2021 .\end{array}$ & TTU-P09214; YPM PV 058121. \\
\hline
\end{tabular}

\section{SYSTEMATIC PALEONTOLOGY}

ARCHOSAURIA Cope, 1869 sensu Gauthier and Padian, 1985

PSEUDOSUCHIA Zittel, 1887-1890 sensu Gauthier and Padian, 1985

AETOSAURIA Marsh, 1884 sensu Parker, 2007

Aetosauroides scagliai Casamiquela, 1960

1960 Aetosauroides scagliai: Casamiquela, p. 2, figs. 1-5.

1960 Argentinosuchus bonapartei: Casamiquela, p. 2, figs. 3-5.

1961 Aetosauroides scagliai: Casamiquela, $p$. 4-188, figs. 1-26, pl. 1.

1961 Argentinosuchus bonapartei: Casamiquela p. 189-201, figs. 27-32.

1967 Aetosauroides scagliai: Casamiquela, $\mathrm{p}$. 173, figs. 1-3, pls. I-XV.

1971a Aetosauroides scagliai: Bonaparte, p. 88, 91, 93, 96, 99-102.

1971b Aetosauroides scagliai: Bonaparte, p. 671, figs. 15, 16.

1973 Aetosauroides scagliai: Bonaparte, p. 113, fig. 4.

1978 Aetosauroides scagliai: Bonaparte, p. 300, figs. 137b, 138.

1982 Aetosauroides: Bonaparte, p. 108, fig. $4 \mathrm{~d}$.

1985 Aetosauroides inhamandensis: Barbarena et al., p. 14

1994 Aetosauroides: Parrish, p. 204.
2002

2002

2002

1996

1996

1996

1998

1998

1998

1999

1999

1999

1999

2000

2001

2001

$2002 a$

2004
Aetosauroides: Heckert, Hunt and Lucas, p. 619, 623, 627-629.

Stagonolepis: Lucas and Heckert, p. 60. Argentinasuchus [sic]: Lucas and Heckert, p. 62.

Stagonolepis: Heckert and Lucas, p. 68, 69.

Stagonolepis (= Aetosauroides): Lucas, p. 398.

'Aetosauroides': Lucas, p. 398.

Aetosauroides: Heckert and Lucas, p. 51, 55, 59, 62.

Argentinosuchus: Heckert and Lucas, p. 51.

Stagonolepis (=Aetosauroides) scagliai: Heckert and Lucas, p. 55, 59, 61, 62.

Stagonolepis robertsoni: Heckert and Lucas, p. 64.

Stagonolepis robertsoni: Heckert and Lucas, p. 1552, fig. 4d.

Stagonolepis: Lucas, p. 14, 15.

Stagonolepis robertsoni: Lucas and Heckert, p. 719, 720, 724, 726, 728-730, figs. 2, 3.

Aetosauroides: Small, p. 109.

Stagonolepis: Lucas and Heckert, p. 37.

Aetosauroides subsulcatus: Da Rosa and Leal, p. 149, 152, 153, fig. 4e, $4 \mathrm{~g}$ only.

Stagonolepis robertsoni: Heckert and Lucas, p. 852-861, figs. 2-4.

Aetosauroides: Desojo and Heckert, p. 610. 
2005 Aetosauroides scagliai: Desojo, p. 65-90.

2007 Aetosauroides: Desojo and Báez, p. 273, 273.

2007 Aetosauroides scagliai: Schoch, p. 11, 21, 22, 31, 33.

2007 Aetosauroides: Irmis, p. 356.

2007 Aetosauroides: Heckert, Lucas, Hunt and Spielmann, p. 49.

2007 Aetosauroides: Parker, p. 54, 56-58.

2008 Aetosauroides: Parker, p. 13, 18, 28.

2011 Aetosauroides scagliai: Cerda and Desojo, p. 417-426, figs. 3, 4.

2011 Aetosauroides scagliai: Desojo and Ezcurra, p. 596, figs. 2-6, 7a, 8.

2011 Aetosauroides scagliai: Desojo, Ezcurra, and Schultz, p. 851-856, 860.

2011 Aetosauroides scagliai: Nesbitt, p. 98, 137, 150, 195, 196.

2012 Aetosauroides scagliai: Desojo, Ezcurra and Kischlat, p. 1-5, 7-13, 15-17, 19, 20, 22, 25, 26, 28, 29.

2013 Aetosauroides scagliai: Desojo, Heckert, Martz, Parker, Schoch, Small and Sulej, p. 1, 2, 4, 7, 11, 13, 15-18, 20, 22, 24, 25.

2013 Aetosauroides scagliai: Taborda, Cerda and Desojo, p. 1-3, 6-10, figs. 3-4.

2013 Aetosauroides scagliai: Small and Martz, p. 1, 17, 18.

2014 Aetosauroides scagliai: Roberto-da-Silva et al., p. 240, 241, 246- 248, 250- 252, 254-259, 261, 264, 267-269, 272, 273, 275.

2014 Polesinesuchus aurelioi: Roberto-daSilva et al., p. 1-275, figs. 4-34.

2014 Aetosauroides scagliai: Parker, p. 4, 6, 7, 10, 12, 34, 46-61, 72-74, 77, 82, 84, 87, $92,94,95,124,126,134,137,139,154$, $160,161,165,209-211,220,231,237$, $260,261,264,265,267,269,270-272$, $274,277,279,284,285,293,297,305$, $306,310,329,330,332,333,335,336$, $342,346,376,377,383$. figs. $3.1,3.2$, 6.2, 6.3b, 6.7d, 6.9e, 6.10a, 6.13c-d.

2014 Polesinesuchus aurelioi: Parker, p. 6, 7, 203, 237, 238, 282, 312, 330, 334.

2014 Aetosauroides scagliai: Scheyer, Desojo and Cerda, p. 241, 252, 257, 258.

2015 Aetosauroides scagliai: Taborda, Heckert and Desojo, p. 173-178, 180, 182-185.

2015 Aetosauroides: Heckert, Scheneider, Fraser and Webb, p. 6, 8.
2016

Aetosauroides scagliai: Ezcurra, p. 15, 97, 98, 110, 114, 136, 141, 168, 185, $186,202,204,209,223,224,228-230$, $237,241,243,245,248,250,252,254$, $258,259,265,266,275,330,337,338$, figs. $43 \mathrm{k}, 43 \mathrm{l}, 43 \mathrm{~g}, 45 \mathrm{~g}$.

2016

Aetosauroides scagliai: Desojo and Ezcurra, p. 59, 60, 63, 64, fig. 3c, 3g, 3h, $3 n$.

2016a Aetosauroides scagliai: Parker, p. 10, 11, 15, 20, 32, 37, 41-44, 47, 51.

2016a Polesinesuchus aurelioi: Parker, p. 6, 22, 23, 40, 41, 43.

2016b Aetosauroides scagliai: Parker, p. 10, 12, 21-23, 35-37, 41, 43, 44, 48.

2016 Aetosauroides scagliai: Schoch and Desojo, p. 74, 81-83, 86, 88, 91.

2016 Polesinesuchus aurelioi: Schoch and Desojo, p. 88.

2018 Aetosauroides scagliai: von Baczko et al., p. 1, 2, 14.

2018 Aetosauroides scagliai: Brust et al., p. 13, 6-19, fig. 2-6.

2018 Aetosauroides scagliai: Hoffman, Heckert and Zanno, p. 2-4, 6, 8, 10,

2018 Aetosauroides scagliai: Cerda, Desojo, and Scheyer, p. 1-8, 10, 12, 14-22, fig. 28.

2018a Aetosauroides scagliai: Parker, 8, 37.

2018b Aetosauroides scagliai: Parker, p. 2, 5, 9, 12, 14-18, 20, 21, 31.

2018b Polesinesuchus aurelioi: Parker, p. 17.

2019 Aetosauroides scagliai: Hoffman, Heckert and Zanno, p. 16.

2019 Polesinesuchus: Hoffman, Heckert, and Zanno, p. 15.

2020 Aetosauroides scagliai: Desojo et al., p. 5, 19, 21, fig. 11.

2020 Aetosauroides scagliai: Marsh et al., p. 9, 11, 18, 19.

2021 Aetosauroides scagliai: Reyes et al., p. 4-7, 9, 11-13, 15, 16.

2021 Aetosauroides scagliai: Czepiński et al., p. $9,11,13,14$.

2021a Aetosauroides scagliai: Paes Neto et al., fig. 2-16.

2021b Aetosauroides scagliai: Paes Neto et al., p. 1-15, figs. 1-10.

Holotype. PVL 2073, partially articulated postcranium of a relatively small individual, probably skeletally immature, as indicated by the open 
neurocentral sutures of the presacral vertebrae (e.g., Heckert and Lucas, 2002; Taborda et al., 2015) and by the low number (5) of lines of arrested growth in osteoderm sections when compared with other individuals (e.g., Cerda and Desojo, 2010; Taborda et al., 2013, 2015; Cerda et al., 2018).

Diagnosis (adapted from Brust et al., 2018). Medium-sized aetosaur (up to $2.45 \mathrm{~m}$ in length) distinguished from other aetosaurs by the following combination of characters (autapomorphies with asterisk): maxilla excluded from the margin of the external nares; ventral margin of the dentary convex and without a sharp inflexion (shared with Typothorax); dorsal margin of the surangular with the presence of a rounded tuber (shared with Stenomyti, Stagonolepis, and Longosuchus); recurved tooth crowns (shared with Coahomasuchus) with denticles on both mesial and distal margins, without wear facets or marked constriction between root and crown; cervical and trunk centra with oval fossae ventral to the neurocentral suture on the lateral sides of the centra; mid- and posterior trunk vertebrae with well-developed posterior infradiapophyseal lamina, directly below the diapophysis (shared with Stagonolepis, Lucasuchus, Longosuchus, Desmatosuchus, and Typothorax); mid- and posterior dorsal vertebrae with posterolaterally divergent postzygapophyses, ratio between the entire length of the postzygapophyses and the width between the distal-most tips of the postzygapophyses less than or equal to $0.75^{*}$; anterior tip of premaxilla slightly expanded laterally (incipiently forming a shovel-shaped tip).

Referred materials. Five referred specimens have been reported from the lower levels of the Ischigualasto Formation, San Juan, Argentina: (1) PVL 2052, a large specimen with much of the posterior portion of the postcranial skeleton well preserved, but also some skull elements preserved as natural casts (Casamiquela, 1967; Heckert and Lucas, 2002; Desojo, 2005; Desojo and Ezcurra, 2011; Parker, 2014; Brust et al., 2018); (2) PVL 2059, a small specimen with a partially preserved skull, with the anterior portion of the carapace preserved in articulation with the corresponding portion of the axial skeleton (Casamiquela, 1960, 1961; Heckert and Lucas, 2002; Desojo, 2005; Desojo and Ezcurra, 2011; Taborda et al., 2013, 2015; Parker, 2014; Brust et al., 2018); (3) PVSJ 326 , a large specimen with a partially preserved skull, isolated trunk and caudal vertebrae, several appendicular elements, and dorsal paramedian and lateral osteoderms (Desojo, 2005; Desojo and
Ezcurra, 2011; Parker, 2014, 2016a; Ezcurra, 2016; Parker, 2016a); (4) PVL 2091, a large specimen with poorly preserved postcranial elements including cervical vertebrae, humerus, and several osteoderms (holotype of 'Argentinosuchus bonapartei'; see Ezcurra, 2016); (5) CRILAR-Pv 580, a small specimen preserving fragmentary teeth, vertebrae, limb elements, and dorsal osteoderms (Desojo et al., 2020b).

Six additional referred specimens are known from the Candelária Sequence, Rio Grande do Sul, Brazil (sensu Paes Neto et al., 2021b): (1) MCP$13-P V$, a small specimen represented by six articulated trunk vertebrae, an articulated portion of the dorsal and ventral armor, several isolated lateral and ventral osteoderms, and fragments of vertebrae, ribs, and osteoderms (Desojo and Ezcurra, 2011; Taborda et al., 2015; Brust et al., 2018); (2) UFSM 11505, a small specimen with a well-preserved skull associated with the postcranium, including armor (Brust et al., 2018); (3) UFSM 11070 , a small specimen preserving most of the posterior portion of the postcranium but lacking the skull (Da-Rosa et al., 2009; Desojo and Ezcurra, 2011; Brust et al., 2018); (4) MCP-3450-PV, a small specimen made up of a fragmentary skull and axial series, with a few appendicular elements and armor (briefly mentioned and figured by Lucas and Heckert, 2001). Following Paes Neto et al. (2021b), we consider this specimen to represent a distinct individual from UFSM-11070, contra a previous interpretation by Desojo and Ezcurra (2011); (5) MCN-PV 2347, a skull associated with a fragmentary postcranium. This specimen is the aetosaur mentioned for the Piche site in the biostratigraphic study of Langer et al. (2007); (6) ULBRAPV003T, a small specimen with almost complete preservation of the axial and appendicular skeleton (see Roberto-da-Silva et al., 2013). This is the holotype of 'Polesinesuchus aurelioi', now considered to represent the most immature specimen known of $A$. scagliai (see Paes Neto et al., 2021a).

Horizon and locality. All of the Brazilian specimens referred to $A$. scagliai come from the HAZ (late Carnian-early Norian), base of the Candelária Sequence, Santa Maria Supersequence, which crops out in the center of Rio Grande do Sul state. The small specimen MCP-13-PV was recovered from the Inhamandá Site (Desojo and Ezcurra, 2011), in São Pedro do Sul town, which is the same site where the type material of Aetobarbakinoides brasiliensis was found (see Desojo et al., 2012). Most of the specimens (UFSM 11070, 
TABLE 2. Comparative measurements of Aetosauroides scagliai skulls, in $\mathrm{mm}$.

\begin{tabular}{lccc}
\hline & $\begin{array}{c}\text { MCN-PV } \\
\mathbf{2 3 4 7}\end{array}$ & $\begin{array}{c}\text { UFSM } \\
\mathbf{1 1 5 0 5}\end{array}$ & $\begin{array}{c}\text { PVL } \\
\text { 2059 }\end{array}$ \\
\hline $\begin{array}{l}\text { Skull total height (from jugal } \\
\text { to parietal) }\end{array}$ & 46.5 & - & - \\
External nares height & 10.4 & 11 & 11 \\
External nares length & - & 39.8 & $\sim 50$ \\
Antorbital fenestra length & 29.6 & 32.9 & - \\
Antorbital fenestra height & $\sim 07.2$ & 12 & - \\
Antorbital fossa length & 36.6 & 45.8 & - \\
Antorbital fossa height & 24.5 & 25.5 & - \\
Orbit height & 24.8 & 33 & - \\
Orbit length & 27.7 & 28.8 & - \\
Infratemporal fenestra & 5.3 & - & - \\
length & & & - \\
Infratemporal fenestra & 10.7 & - & - \\
height & & & - \\
$\begin{array}{l}\text { Supratemporal fenestra } \\
\text { length }\end{array}$ & $\sim 20$ & - & \\
Supratemporal fenestra & 22.3 & - & \\
height & & & \\
\hline & & & \\
\hline
\end{tabular}

UFSM 11505, and MCP-3450-PV) come from the Faixa Nova site, within Santa Maria city (Da-Rosa and Leal, 2002). MCN-PV 2347 was collected at the the Piche site (Figure 1E), an outcrop not far from the Buriol site that yielded the specimen ULBRAPV003T, both within the São João do Polêsine area.

\section{Description}

Skull. The skull of MCN-PV 2347 is triangular in both dorsal and lateral views (Tables 2 and 3; Figures 2 and 3 ), as in all aetosaurs. The preserved antorbital region represents more than half of the skull length, consistent with other known specimens of Aetosauroides scagliai (PVL 2059 and UFSM 11505) and other aetosaurs. The nares are anteroposteriorly elongated, as in other non-aetosaurine aetosaurs (see Reyes et al., 2021). The antorbital fenestra is anteroposteriorly elongate and dorsoventrally short (being four times longer than tall). The shape of its anterior end is acute, as in other A. scagliai specimens (PVL 2059 and UFSM 11505; 'oval' of Brust et al., 2018), contrasting with the round shape of other aetosaurs like Desmatosuchus smalli Parker, 2005 (TTU P-9024) and Stenomyti huangae Small and Martz, 2013 (DMNH 60708). The supratemporal fenestra is sub-oval and exposed laterally, equal to two-thirds of the orbital length, as in most aetosaurs (e.g., Desojo et al., 2013) but unlike Paratypothorax
TABLE 3. Measurements of the skull of Aetosauroides scagliai specimen MCN-PV 2347, in mm.

\begin{tabular}{lc}
\hline Premaxilla height & $\sim 4.5$ \\
Maxilla length & $\sim 70.8^{*}$ \\
Maxilla height & $\sim 25.7^{*}$ \\
Nasal maximum width & 12.7 \\
Nasal length (preserved) & 63.1 \\
Prefrontal length & 19.5 \\
Prefrontal height & - \\
Lacrimal length & $\sim 30.0$ \\
Lacrimal height & 18.5 \\
Frontal length & $\sim 30$ \\
Frontal width & 14.2 \\
Postfrontal length & $\sim 8.7$ \\
Parietal length & 18.7 \\
Parietal width & 2.22 \\
Jugal length & 42.1 \\
Jugal height & 10.0 \\
Quadratojugal ventral length & 16.6 \\
Quadratojugal height & 16.1 \\
Squamosal dorsal length & 16.0 \\
Squamosal maximum height & $\sim 31.1$ \\
\hline
\end{tabular}

${ }^{*}$ combined measurements from the left and right element

andressorum Long and Ballew, 1985 (Schoch and Desojo, 2016). The infratemporal fenestra is triangular and reduced, representing one third the length of the supratemporal fenestra.

The skull roof of MCN-PV 2347 is ornamented with grooves and pits near the orbital region and on the anterior half of the parietal (Figure 2). As in some aetosaurs, in dorsal view, two paramedian grooves run anteroposteriorly near the lateral rim of the skull roof across the frontal and nasals (Figure 2: lg). These grooves connect to each other anteromedially, forming a V-shaped structure at the posterior portion of the nasals (see character 11 of Parker, 2016a). In MCN-PV 2347, this structure is not as deep as in Paratypothorax andressorum (SMNS 19003), but is more clearly delimited than in Desmatosuchus smalli (TTU P-9024; Small, 2002). Posteriorly, these grooves fuse with the transverse sulcus of the parietal.

Premaxilla: The anterior portions of both premaxillae are missing in MCN-PV 2347 (Figures 2-4). However, the preserved region shows that the premaxilla forms the ventral margin of the external naris (Figures 3-4), as in all aetosaurs. The right premaxilla is slightly displaced ventrally, and its contact with the nasal is less evident, as the nasal 


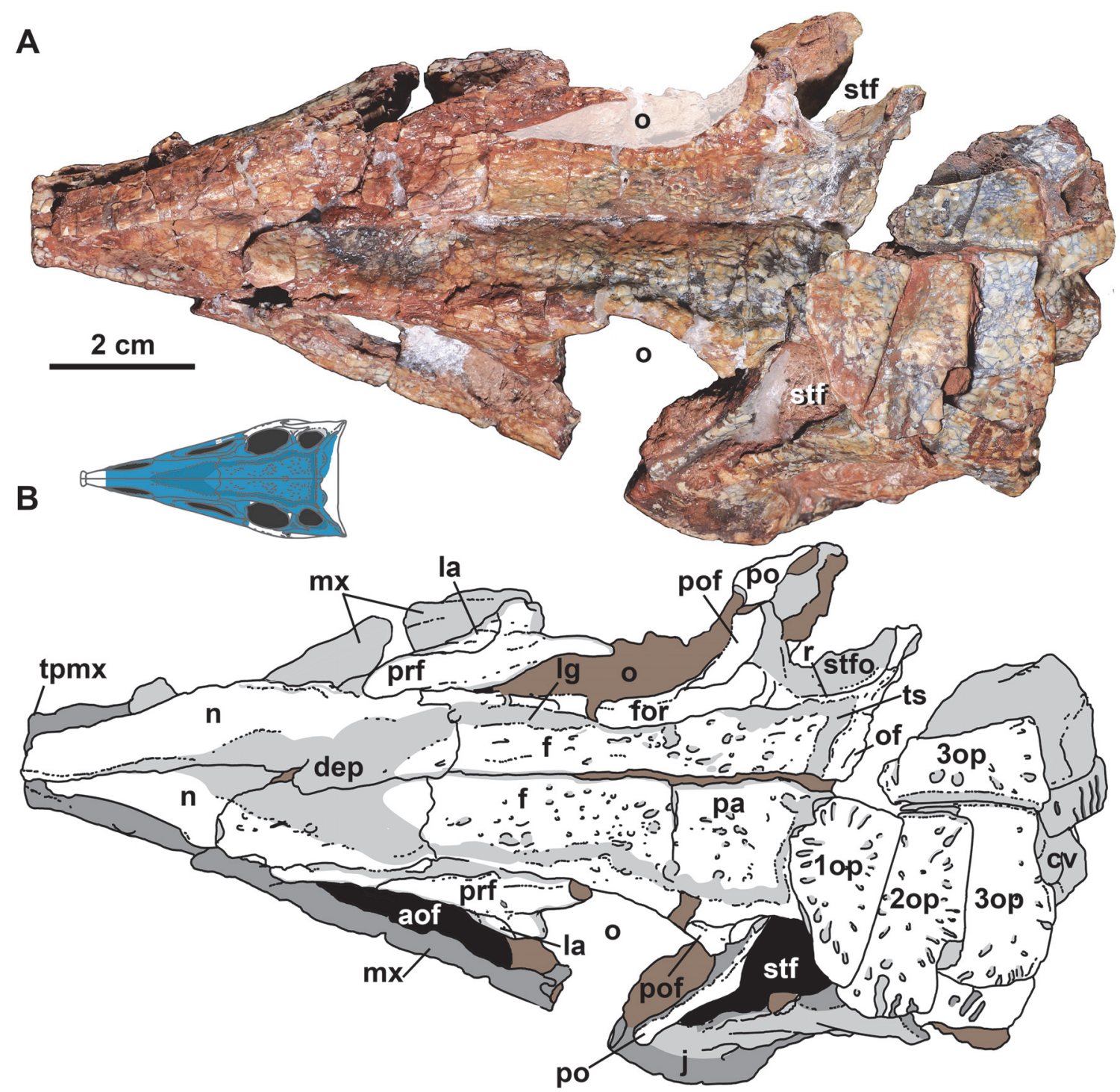

FIGURE 2. Skull of Aetosauroides scagliai (MCN-PV 2347) in dorsal view. A, photograph. B, interpretative drawing with matrix shown in brown. Abbreviations: aof, antorbital fenestra; cv, cervical centra; dep, nasal depression; f, frontal; for, frontal elevated orbital rim; j, jugal; la, lacrimal; lg, lateral groove; mx, maxilla; n, nasal; o, orbit; of, overhanging flange; op, paramedian osteoderm; pa, parietal; po, postorbital; pof, postfrontal; prf, prefrontal; r, ridge; stf, supratemporal fenestra; stfo, supratemporal fossa; tpmx, thorn-like lateral projection of the premaxilla; ts, transverse groove.

is displaced dorsally. The left premaxilla is fragmented at its posterior end, but is still in articulation with the descending process of the nasal as in other Aetosauroides scagliai specimens (e.g., PVL 2052; PVL 2059, and UFSM 11505). It thus excludes the maxilla from the external narial margin, which is unique among aetosaurs (Casamiquela, 1961, 1967; Desojo and Ezcurra, 2011; Brust et al., 2018) representing the plesiomorphic condition (e.g., Desojo, 2005; Parker, 2016a).

At least four tooth alveoli are preserved in each premaxilla of MCN-PV 2347. The three posterior premaxillary teeth are preserved in the left premaxilla (Figure 5E: pmtx), although they are not oriented as in life. Brust et al. (2018) stated that five teeth were present in the right premaxilla of Aetosauroides scagliai (UFSM 11505), but we could observe only four in this specimen. Erpetosuchids (Ezcurra et al., 2017), gracilisuchids (Lecuona, 2012), and the aetosaurs Aetosaurus ferratus Fraas, 1877 (Schoch, 2007), Neoaetosauroides engaeus Bonaparte, 1969 (Desojo and Báez, 2007) and Paratypothorax andressorum (according to Schoch and Desojo, 2016) share this premaxillary tooth count. This number varies in other related taxa, such as Desmatosuchus smalli 


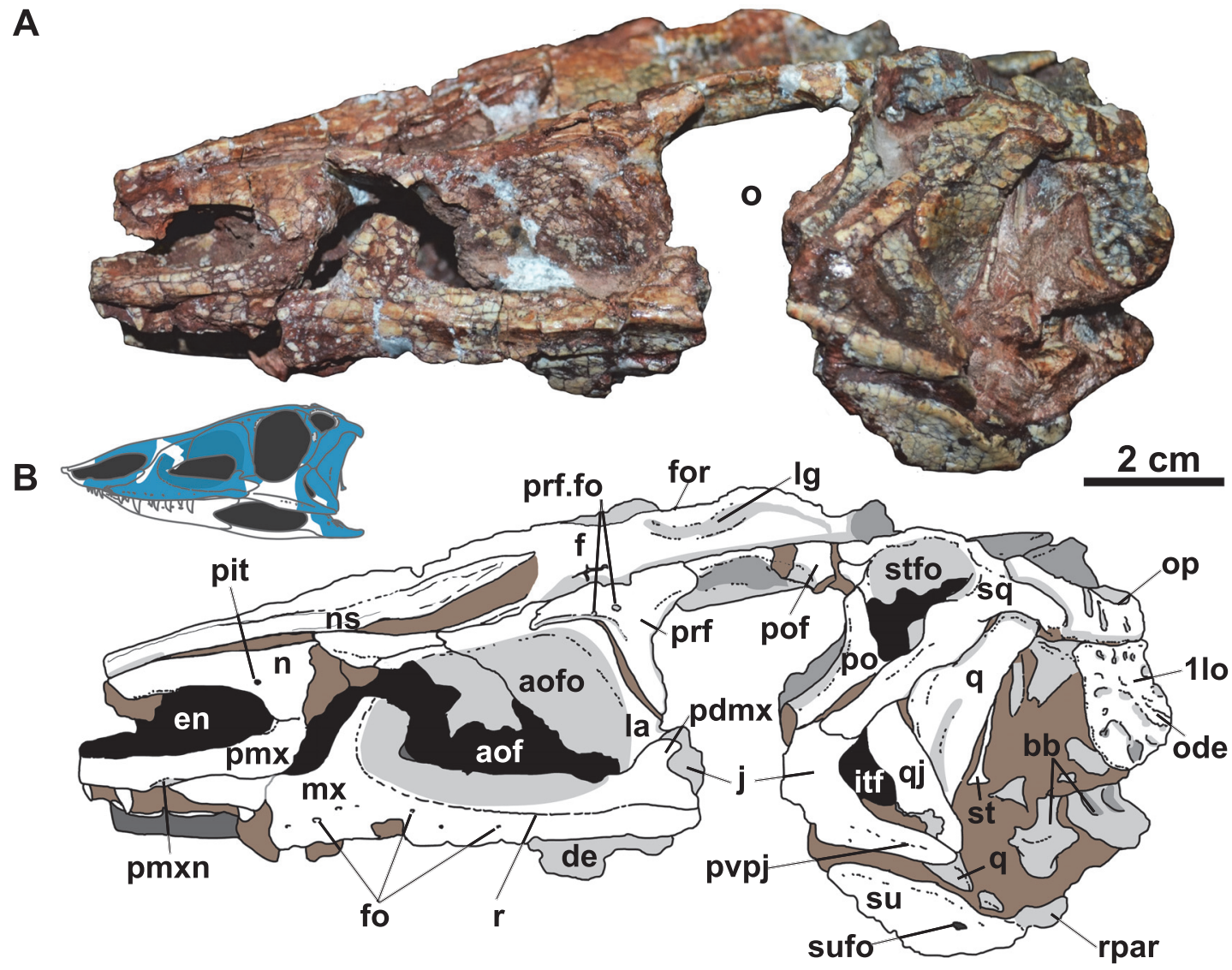

FIGURE 3. Skull of Aetosauroides scagliai (MCN-PV 2347) in left lateral view. A, photograph. B, interpretative drawing. Abbreviations: aof, antorbital fenestra; aofo, antorbital fossa; bb, braincase bones; de, dentary; en, external naris; $f$, frontal; fo, foramina; for, frontal elevated orbital rim; itf, infratemporal fenestra; j, jugal; la, lacrimal; lg, lateral groove; lo, dorsal lateral osteoderm; mx, maxilla; $\mathrm{n}$, nasal; $\mathrm{ns,} \mathrm{nasal} \mathrm{suture;} \mathrm{ode,} \mathrm{osteoderm} \mathrm{dorsal} \mathrm{eminence;} \mathrm{o,} \mathrm{orbit;} \mathrm{op,} \mathrm{dorsal}$ paramedian osteoderm; pdmx, posterodorsal process of the maxilla; pmx, premaxilla; pmxn, premaxilla notch; prf, prefrontal; prf.fo, prefrontal foramen; po, postorbital; pof, postfrontal; pvpj, posteroventral process of the jugal; q, quadrate; qj, quadratojugal; r, ridge; rpar, retroarticular process of the articular; sq, squamosal; st, stapes; stfo, supratemporal fossa; su, surangular; sufo, surangular foramen.

(which is edentulous; Small, 2002), Stenomyti huangae (which has three premaxillary teeth; Martz and Small, 2013), Typothorax coccinarum Cope, 1874 (five; Reyes et al., 2021), both Stagonolepis species (four to five; Walker, 1961; Sulej, 2010), and ornithosuchids (three; von Baczko and Desojo, 2016).

A thorn-like lateral projection is present dorsal to the first and second alveoli in the premaxilla of MCN-PV 2347 (Figures 4-5: tpmx). This position contrasts with the location in another specimen of Aetosauroides scagliai (UFSM 11505), in which the projection is dorsal to the second and third alveoli (Brust et al., 2018), and with Paratypothorax andressorum (SMNS 19003; dorsal to the second/ third alveoli) and Stagonolepis olenkae Sulej, 2010 (dorsal to the second alveolus according to the original description). Small and Martz (2013) con- sidered this projection to be absent in Stenomyti huangae; however, as observed by Parker (2016a), a slight dorsal swelling on the type skull above the second tooth alveolus is preserved, similar to the condition in A. scagliai. Intraspecific variation (see Schoch and Desojo, 2016) in the shape as well as the location of this projection may occur; in UFSM 11505 it is more acute, but in the similarly-sized specimen MCN-PV 2347 it is lower and mound-like.

In lateral view, the ventral margin of the premaxilla forms a distinct notch (Figures 3-5: pmxn) anterior to the contact with the anterior process of maxilla, resembling the condition in Paratypothorax andressorum (SMNS 19003; Schoch and Desojo, 2016). This recess is formed by a medial deflection of the ventral margin of the premaxilla, which is also preserved in other referred specimens of 


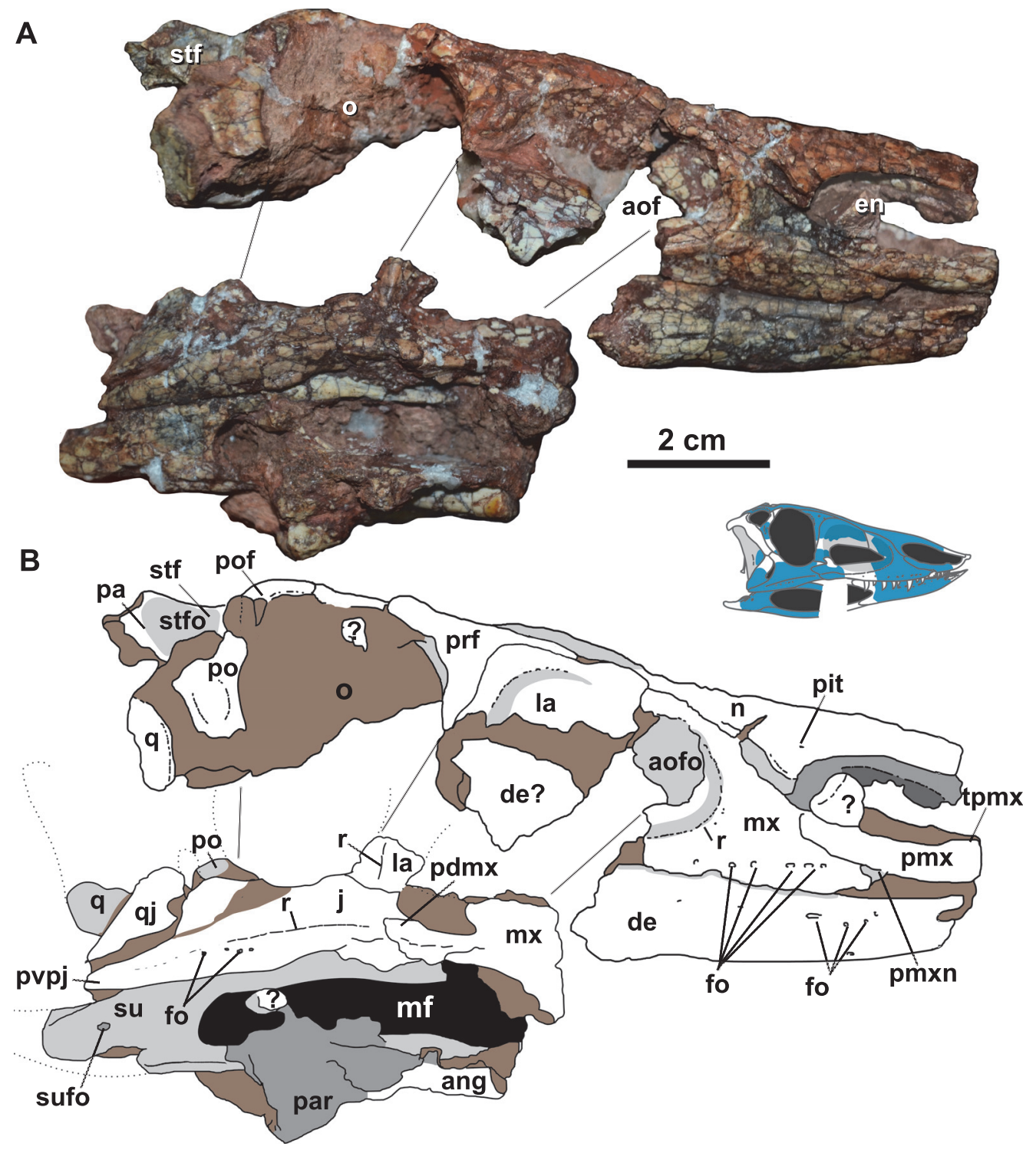

FIGURE 4. Skull of Aetosauroides scagliai (MCN-PV 2347) in right lateral view. A, photograph. B, interpretative drawing with matrix shown in brown. Abbreviations: ang, angular; aof, antorbital fenestra; aofo, antorbital fossa; de, dentary; en, external naris; fo, foramina; j, jugal; la, lacrimal; mf, mandibular fenestra; mx, maxilla; $\mathrm{n}$, nasal; o, orbit; pa, parietal; par, prearticular; pdmx, posterodorsal process of the maxilla; pmx, premaxilla; pmxn, premaxilla notch; prf, prefrontal; po, postorbital; pof, postfrontal; pvpj, posteroventral process of the jugal; q, quadrate; qj, quadratojugal; r, ridge; stf, supratemporal fenestra; stfo, supratemporal fossa; su, surangular; sufo, surangular foramen; tpmx, thornlike lateral projection of the premaxilla.

Aetosauroides scagliai (PVL 2059 and UFSM 11505 , although poorly preserved in the later) and in Stagonolepis olenkae (ZPAL AbIII 2151), but appears to be absent in Stagonolepis robertsoni (ELGNM 38) and Stenomyti huangae (DMNH 60708).

In the preserved anterior portion, both premaxillae contact each other medially, possessing a marked medial ridge that runs antero-posteriorly at the symphyses (Figures 5-6). A ventromedial shelf projects posteriorly, contacting the maxilla medially. This process is similar to those found in Desmatosuchus smalli (Small, 2002), Stagonolepis robertsoni (NSM R 4784; Walker, 1961), and Stagonolepis olenkae (Sulej, 2010). The foramen incisivum is present as a slightly concave medial edge of each medial shelf (Figure 5D and E: fi), but comparatively smaller than in Desmatosuchus smalli (Small, 2002). 


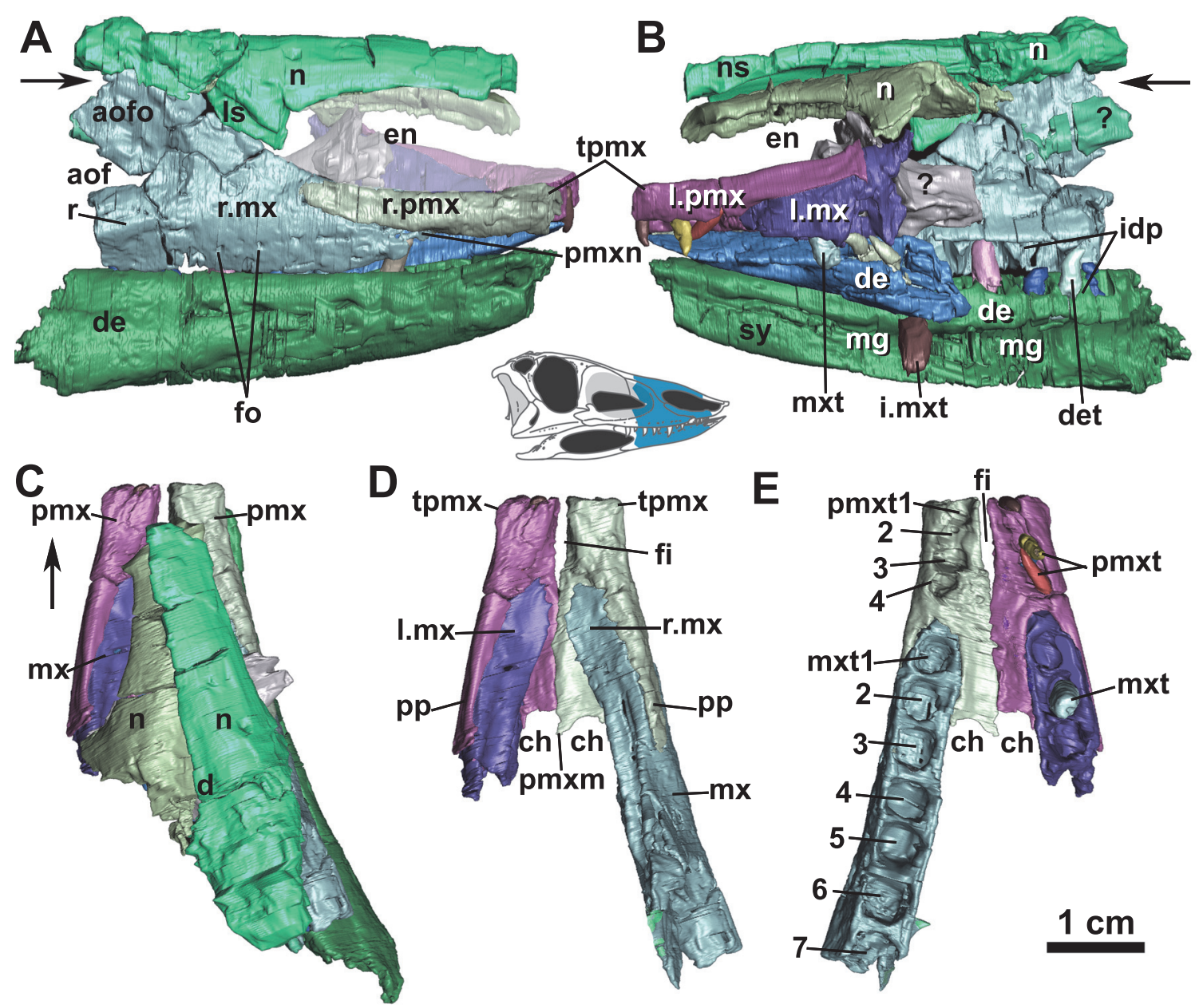

FIGURE 5. Three-dimensional reconstruction based on $\mu$ CT-scan images of the rostrum of Aetosauroides scagliai (MCN-PV 2347). A, right lateral view. B, left lateral view. C, dorsal view. D, dorsal view without the nasals. E, ventral view without the dentary. Abbreviations: aof, antorbital fenestra; aofo, antorbital fossa; ch, choana; d, depression; de, dentary; en, naris; fi, foramen incisivum; fo, foramina; i.mxt, isolated maxillary teeth; idp, interdental plates; I., left; Is, lateral socket of the nasal; mg, Meckelian groove; mx, maxilla; mxt, maxillary alveoli/tooth; $n$, nasal; ns, nasal suture; pmx, premaxilla; pmxm, medial process of the premaxilla; pmxn, premaxillary notch; pmxt, premaxillary alveoli/tooth; $\mathrm{pp}$, posterior process; r, ridge; r.,right; sy, symphysis; tpmx, thorn-like lateral projection of the premaxilla.

Maxilla: The maxilla is an anteroposteriorly elongated bone that forms the anterodorsal and ventral border of the antorbital fenestra (Figures 3-6). As in other aetosaurs, it contacts the premaxilla anteromedially and the nasal dorsally. The ascending process (= facial process) contacts the lacrimal posteriorly, and its posterior process overlaps the jugal. The anterior process of the maxilla is acute in lateral and dorsal views and relatively short (nearly one third of the maxillary length) for an aetosaur, albeit still longer than in most erpetosuchids and ornithosuchids (von Baczko and Desojo, 2016; Ezcurra et al., 2017; Lacerda et al., 2018). It bears a slot for the premaxilla on its dorso-lateral rim, as in other aetosaurs (e.g.,
Small, 2002) and similar to the condition in some poposauroids (e.g., Nesbitt, 2011).

The ascending process of the maxilla has a concave anterior margin and constitutes nearly two thirds of the maxillary length, similar to other Aetosauroides scagliai specimens (PVL 2059 and UFSM 11505) and some other aetosaurs (e.g., Paratypothorax andressorum; Schoch and Desojo, 2016). It bears a ridge that delimits the margins of the antorbital fossa, which extends to the posterior process of the maxilla (Figures 3-5: r), as in other A. scagliai skulls (e.g., PVL 2052, PVL 2059, and UFSM 11505). In $A$. scagliai, this ridge is not as prominent or raised (Brust et al., 2018) as in $P$. andressorum (SMNS 19003; Schoch and Desojo, 

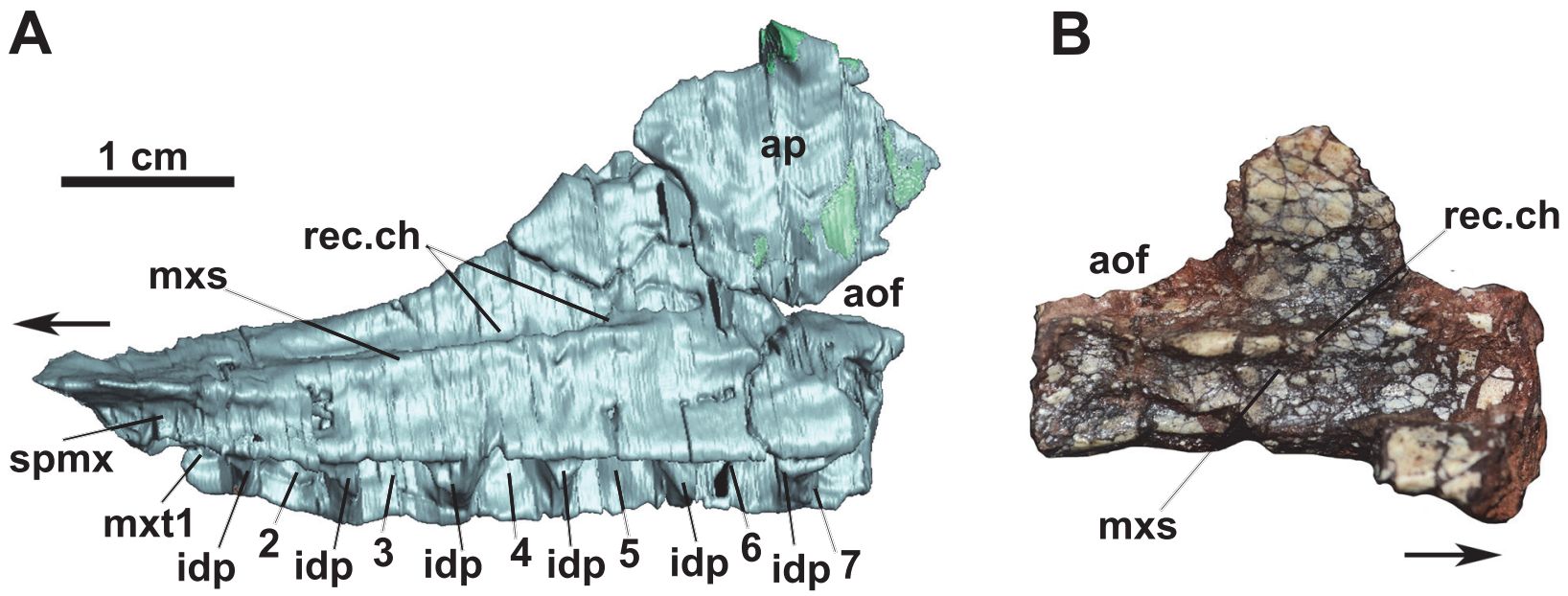

FIGURE 6. 3D Reconstruction based on $\mu C T$-scan images and photograph of Aetosauroides scagliai maxillae (MCNPV 2347). A, right maxilla in medial view. B, left maxilla fragment in medial view. Abbreviations: aof, antorbital fenestra; ap, ascending process; idp, interdental plates; mxs, maxilla medial shelf; mxt, maxilla alveoli; rec.ch, choanal recess; spmx, slot for the premaxilla.

2016) or Stagonolepis olenkae (ZPAL AbllI/1996 and ZPAL AbIlI/1997; Sulej, 2010), being more similar to the condition in cf. Calyptosuchus wellesi (UCMP 78695 and 195192; Parker, 2018), Stagonolepis robertsoni (NMS R4787), and Aetosaurus ferratus (SMNS 5770 S-16; Schoch, 2007). It is, however, more evident than the faint ridge delimiting the entire fossa in Longosuchus meadei (Sawin, 1947) (TMM 31185-84; although it becomes thicker posteriorly) or only delimiting the anterior border of the fossa in Desmatosuchus spurensis Case, 1920 (UMMP V7476) and Desmatosuchus smalli (TTUP 9024). A series of at least 10 nutrient foramina run dorsal to the ventral margin of the maxilla (Figures 3-5: fo) and ventral to the level of the antorbital fossa, resembling other aetosaurs (Aetosaurus ferratus: $14 ; P$. andressorum: $\sim 11$; $D$. smalli: $\sim 10$ ), erpetosuchids (e.g., Nesbitt and Butler, 2013; Ezcurra et al., 2017), loricatans (e.g., Mastrantonio et al., 2019), and gracilisuchids (e.g., MCZ 4117), although these foramina seem to be absent in ornithosuchids (von Baczko and Desojo, 2016).

The ventral margin of the maxilla is nearly straight, resembling the condition in other Aetosauroides scagliai specimens (UFSM 11505; Brust et al., 2018) and some other aetosaurs, such as Paratypothorax andressorum (SMNS 19003), Aetosaurus ferratus (SMNS 5770 S-16; Schoch, 2007), and cf. Calyptosuchus wellesi (UCMP 78695 and UCMP 195192), as well as the gracilisuchid Gracilisuchus stipanicicorum Romer, 1972 (MCZ 4116 and MCZ 4117). This contrasts with the concave maxilla of most other pseudosuchians (e.g., Mastrantonio et al., 2019), including aetosaurs such as Typothorax coccinarum (according to Heckert and Lucas, 2010; Reyes et al., 2021), Longosuchus meadei (TMM 31185-84), Desmatosuchus smalli (TTUP 9024), Stagonolepis robertsoni (NMS R4787; Walker, 1961), and Stagonolepis olenkae (e.g., ZPAL Ablll 1996 and 1997; Sulej, 2010). As in A. ferratus and $P$. andressorum (Schoch and Desojo, 2016), the posterior region of the maxilla of MCN-PV 2347 is constricted prior its end, which is also the case of UFSM 11505 (better observed in the left element).

The posterior process of the maxilla is low and elongate, reaching the anterior half of the orbit where it expands ventrally and dorsally (Figure 3 : pdmx), forming a posterodorsal process (sensu Butler et al., 2014), as other aetosaurs and gracilisuchids (Butler et al., 2014). This process, in lateral view, terminates in a triradiate finger-like projection in MCN-PV 2347 (see Discussion), not as a rectangle as described for UFSM 11505, which was based on the broken distal end of the right element (Brust et al., 2018: figure 2). The triradiate posterior process is better observed on the left side of UFSM 11505 (Brust et al., 2018: figure 3), which, like in the left maxilla of MCN-PV 2347, reveals that the longest projection is the medial one (see Discussion).

The posterodorsal process of the maxilla in MCN-PV 2347 clearly overlaps the jugal (Figures 3 and 7: pdmx), as in UFSM 11505. The nature of its contact with the lacrimal is less clear in MCN-PV 2347 , as it is dorsally displaced on the left side. The right side is also difficult to interpret, but it 

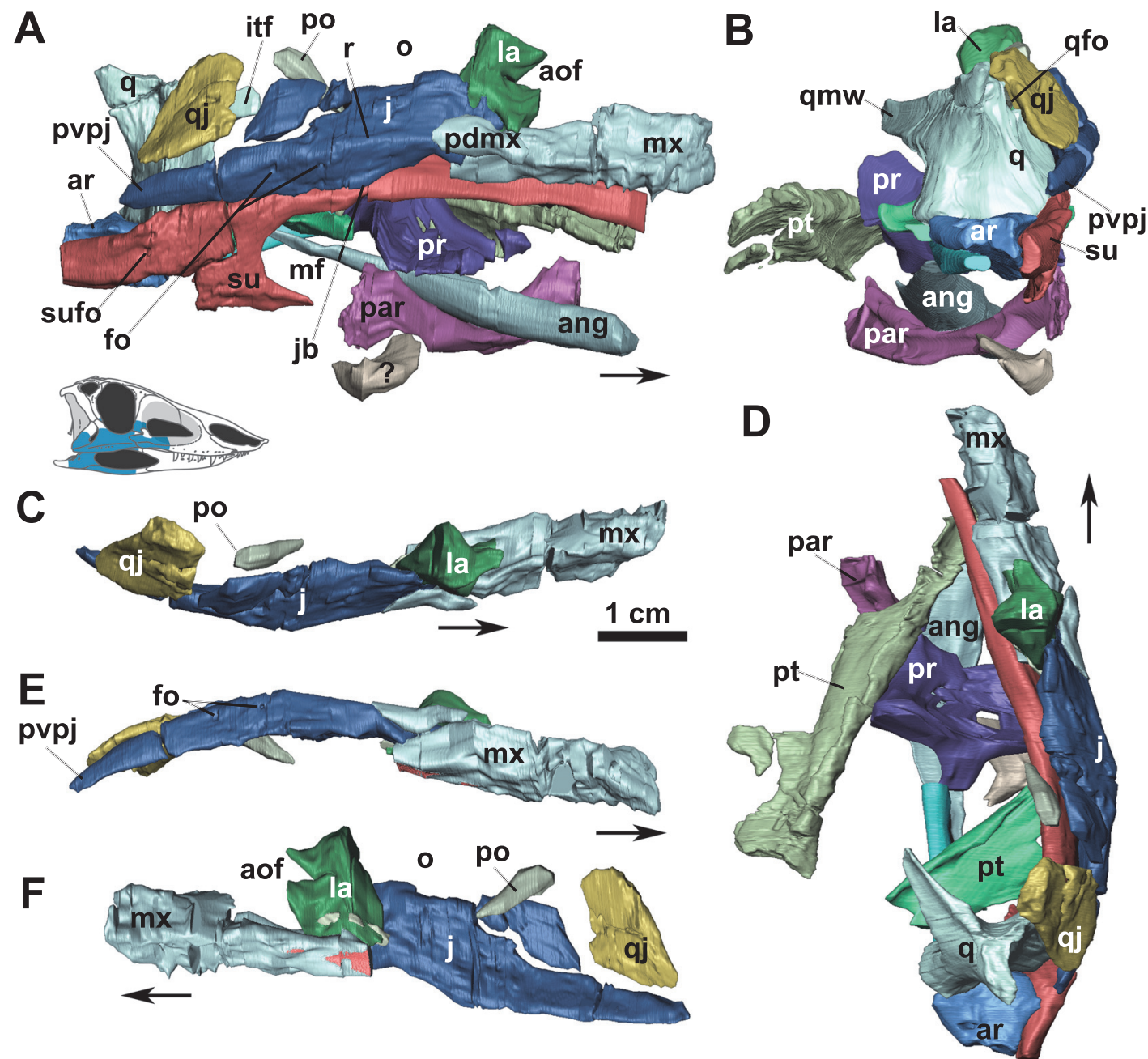

FIGURE 7. Three-dimensional reconstruction based on $\mu$ CT-scan images of the right posterior portion of the skull and mandible of Aetosauroides scagliai (MCN-PV 2347). A, in lateral view. B, in posterior view. C, in dorsal view, without palatal and mandible elements. $D$, in dorsal view. $E$, in ventral view, without palatal and mandibular elements. $F$, in medial view, without palatal and mandibular elements. Abbreviations: ang, angular; aof, antorbital fenestra; ar, articular; fo, foramina; itf, infratemporal fenestra; j, jugal; jb, jugal ventral bend; la, lacrimal; mf, mandibular fenestra; mx, maxilla; o, orbit; par, prearticular; pdmx, middle finger-like projection of the posterior end of the maxilla; po, postorbital; pr, prootic; pt, pterygoid; pvpj, posteroventral process of the jugal; q, quadrate; qfo, quadrate foramen; qj, quadratojugal; qmw, quadrate medial wing; r, ridge; su, surangular; sufo, surangular foramen.

seems to articulate dorsomedially. In UFSM 11505, the posterodorsal process seems to contact the lacrimal dorsomedially, which articulates ventrally with the jugal. This resembles the condition in Paratypothorax andressorum (SMNS 19003; Schoch and Desojo, 2016). In Desmatosuchini, the relationship between the maxilla, lacrimal, and jugal is complex and variable (e.g., Parrish, 1994; Small, 2002). In Longosuchus meadei, the maxilla contacts the lacrimal (also visible in medial view in TMM 31185-84; Parrish, 1994) in a tight suture, not a loose contact. In Desmatosuchus smalli (TTUP 9024), the posterior process of the maxilla articulates with the jugal in a plug-and-socket articula- tion, although with some lateral overlapping between the elements (Small, 2002).

In medial view, the anterior process of the maxilla has a short groove for articulation with the medial process of the premaxilla (Figure 6A: spmx), as in Desmatosuchus smalli (TTUP 9024). The medial surface of the maxilla bears a distinct ridge-like medial shelf (Figure 6: mxs), or palatal process, which runs dorsal and parallel to the tooth row. This medial shelf is also present in erpetosuchids (the 'medial ridge' of Nesbitt and Butler, 2012) and other aetosaurs, such as Stagonolepis robertsoni (NMS R4787), cf. Calyptosuchus wellesi (UCMP 78695 and 195192; Parker, 2018), 
Stagonolepis olenkae (ZPAL Ablll/1996), Desmatosuchus smalli (TTUP 9024; Small, 2002), Longosuchus meadei (TMM 31185-84), Stenomyti huangae (Small and Martz, 2013), and Kocurypelta silvestris (Czepiński et al., 2021). As in other aetosaurs, the medial shelf does not meet its counterpart medially, lacking the palatal process typical of other pseudosuchians (e.g., Nesbitt and Butler, 2012; Mastrantonio et al., 2019).

At the level of the anterior margin of the ascending process, dorsal to the medial shelf, a shallow depressed area is present anteriorly (Figure 6: rec.ch), which we interpret as the choanal recess of Witmer (1997), Small (2002), and Small and Martz (2013). Interestingly, distinct from most other aetosaurs in which the medial surface of the maxilla is known, no pneumatic accessory cavity or round ridge is present posterior to the choanal recess in MCN-PV 2347. This condition is otherwise known only in Typothorax coccinarum within the clade (Reyes et al., 2021).

The number of maxillary alveoli is difficult to establish, but based on CT-data seven are preserved on the right side of MCN-PV 2347 (Figures 5-6: $\mathrm{mxt}$ ). As this element lacks its posterior process, the total number would have been higher; we estimate that there would have been 10-12 alveoli, in keeping with previous estimates for other Aetosauroides scagliai skulls (e.g., Heckert and Lucas, 2002), Stagonolepis robertsoni (Walker, 1961), and Desmatosuchus smalli (Small, 2002). Other aetosaurs have fewer maxillary teeth, such as the eight indicated for Typothorax coccinarum (Reyes et al., 2021) and Neoaetosauroides engaeus (Desojo and Báez, 2007) and the nine teeth of Aetosaurus ferratus (Schoch, 2007) and Stenomyti huangae (Small and Martz, 2013). The alveoli are separated by small and sub-triangular (pointed ventral to the rim of the bone) interdental plates (Figure 6A: idp), resembling those of other aetosaurs (e.g., Stagonolepis olenkae, ZPAL Ablll 547; Sulej, 2010; D. smalli, TTUP 9024; Longosuchus meadei, TMM 31185-84). The alveoli extend toward the posterior portion of the maxilla as in most pseudosuchians, but differing from the condition in erpetosuchids (Benton and Walker, 2002; Nesbitt and Butler, 2013; Ezcurra et al., 2017) and the recentlydescribed aetosaur Kocurypelta silvestris (Czepiński et al., 2021).

Nasal: The anterior portions of both nasals are missing in MCN-PV 2347 (Figures 2-5), and these bones have been displaced from their life positions. The left nasal is dislocated medially (Figure $5 \mathrm{C}$ ) and is covered anteriorly by the right element.
The descending process surrounds the posterodorsal border of the external nares, articulating with the premaxilla (Figure 5A-B), as in other Aetosauroides scagliai specimens (PVL 2052, PVL 2059 and UFSM 11505; Casamiquela, 1961; Desojo and Ezcurra, 2011; Brust et al., 2018) and most other archosauriforms (Nesbitt, 2011), but contrasting with all other aetosaurs (e.g., Parker, 2016a). The descending process of the nasal articulates ventrally with the ascending process of the maxilla, with a lateral contact formed by a longitudinal socket on the lateral surface of the nasal (Figure 5A: Is). The condition in other aetosaurs is unclear, but a similar structure may be present in Stagonolepis olenkae (ZPAL Ablll 2000).

Posteriorly, the nasals articulate with the frontals near the middle portion of the antorbital fenestra. The suture is difficult to establish but appears to have the posterior end slightly divided into two projections by an acute process of the frontal (best seen on the left nasal; Figure 2). The nasals also have a medial depression (Figures 2 and $5 \mathrm{C}$ : $\mathrm{d}$ ), as described by Brust et al. (2018) for UFSM 11505, at the level of the posterior border of the naris. This depression forms a V-shaped outline on the skull roof as in most other aetosaurs (see character 11 of Parker, 2016a), albeit not in Stagonolepis olenkae (Parker, 2016a), Desmatosuchus smalli (TTUP 9024 and TTUP 9420), and Desmatosuchus spurensis (Parker, 2016a). The depression is delimited by a round lateral margin that lacks intense sculpturing. Similar to UFSM 11505 (Brust et al., 2018), only pits are present in the depressed surface of MCN-PV 2347, although more extensive ridges and pits are present in other Aetosauroides scagliai specimens (PVL 2059 and PVL 2052), which may indicate intraspecific variation, probably related to ontogeny (see Taborda et al., 2013, 2015). On the lateral surface of the nasal of MCNPV 2347, a pit is preserved just posterior to the external nares (Figures 3-4: pit), as in S. olenkae (ZPAL AbIll/2000).

The nasal is anteroposteriorly longer than the frontal and parietal combined (see Table 3), as in most aetosaurs other than Stenomyti huangae (according to Small and Martz, 2013). In lateral view, the nasal is nearly straight with a convex dorsal outline close to the level of the posterior end of the nares (Figure 3). The medial surface where each nasal articulates is flat with shallow longitudinal ridges at the medial margin that suture with the counterpart. In cross-section, the nasals of MCNPV 2347 are dorsoventrally thin, with a slightly concave internal margin, contrasting with the thick and 
triangular nasal morphology of Scutarx deltatylus Parker, 2016a (Parker, 2016b). The internal nasal surface is smooth, lacking a longitudinal ridge like that observed in Longosuchus meadei (as indicated by Witmer, 1997).

Jugal: The jugals are unknown in the Argentinian materials of Aetosauroides scagliai, and are only partially preserved in the Brazilian specimen UFSM 11505 , in which the posterior portion is missing (Brust et al., 2018). The right jugal of MCN-PV 2347 is fairly complete (Figure 7F), but only the posterior end of the left jugal (Figure 8 ) is preserved in this specimen (and in MCP-3450-PV). Additionally, there is an undescribed jugal pertaining to the immature specimen ULBRAPV003T (the holotype of 'Polesinesuchus aurelioi'). The jugal is a relatively long and dorso-ventrally low element, forming the entire ventral margin of the orbit (Figure 7A). It resembles the jugals of Stenomyti huangae (DMNH 60708 and 61394), the putative juvenile holotype of Coahomasuchus chathamensis Heckert et al., 2017 (NCSM 23618), and one of the smallest known skulls of Aetosaurus ferratus Fraas, 1877 (SMNS 5770 S-21). This condition contrasts with the dorsoventrally deep jugals of other aetosaurs, such as Paratypothorax andressorum (SMNS 19003), Typothorax coccinarum
(Reyes et al., 2021), Desmatosuchus spurensis (UMMP V7476), Desmatosuchus smalli (TTUP 9023), and some larger specimens of $A$. ferratus (SMNS 5770 S-16). For more details, see Discussion.

The main body and the posterior process of the jugal are anteroposteriorly straight, but the posterior process is ventrally inclined (Figure 7). This contrasts with the ventrally oriented jugals of desmatosuchine aetosaurs (e.g., Longosuchus meadei, TTUP 31185-84; Desmatosuchus smalli, TTUP 9024; and Desmatosuchus spurensis, UMMP V7476), and the straight ones of aetosaurine aetosaurs (e.g., Paratypothorax andressorum, SMNS 19003, Schoch and Desojo, 2016; and Typothorax coccinarum, Reyes et al., 2021), more closely resembling the intermediate condition of the non-desmatosuchine stagonolepidoid Neoaetosauroides engaeus (PULR 5698). Brust et al. (2018) stated that the jugal is not constricted in Aetosauroides scagliai based on UFSM 11505, but constriction in this specimen is only not evident due to the missing posterior process of the jugal. In MCN-PV 2347, a clear constriction is observed in the right element at the mid-level of the orbit (Figures 4 and 7 ). The constriction is marked by a ven-

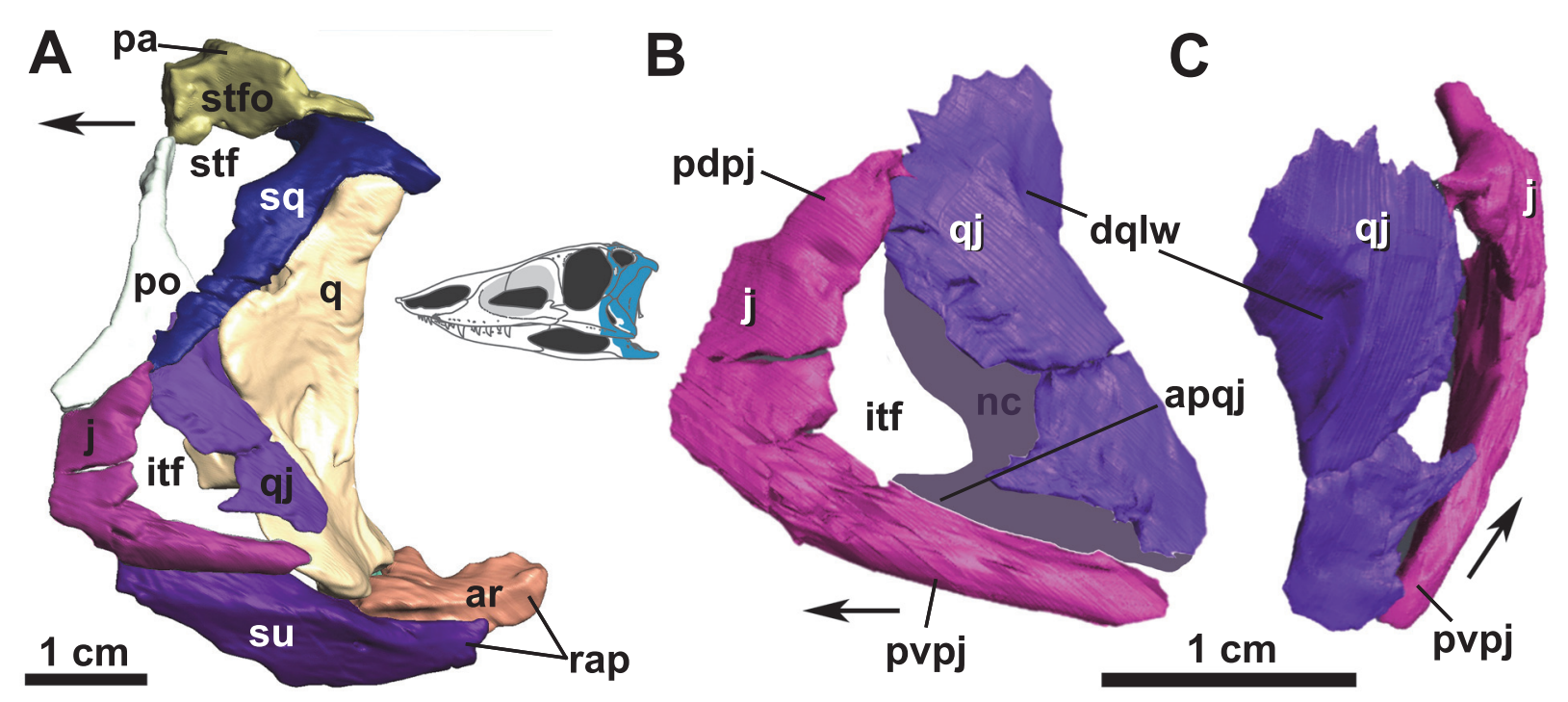

FIGURE 8. A, 3D Reconstruction based on $\mu \mathrm{CT}$-scan images of the posterior portion of the left side of the skull of Aetosauroides scagliai (MCN-PV 2347). B, isolated broken left jugal and quadratojugal, in lateral view. C, $\mu$ CT-scan images of the isolated broken jugal and quadratojugal, in dorsolateral view; Abbreviations: apqj, natural cast of the anterior projection of the quadratojugal; ar, articular; dqlw, depression for quadrate lateral wing; itf, infratemporal fenestra; j, jugal; nc, natural cast of the quadratojugal; pa, parietal; pdpj, posterodorsal process of the jugal; po, postorbital; pvpj, posteroventral process of the jugal; q, quadrate; qj, quadratojugal; rap, retroarticular process; sq, squamosal; su, surangular; stf, supratemporal fenestra; stfo, supratemporal fossa. 
tral 'bend' formed by the ventral border of the element (Figure 7A: jb).

As in UFSM 11505, the anterior process of the jugal is overlapped laterally by the posterior process of the maxilla in MCN-PV 2347 (Figures 4 and $7 \mathrm{~A}, \mathrm{E}$ and $\mathrm{F}$ ). On the right side, the anterior process of the jugal seems to dorsally contact the descending process of the lacrimal (Figures 4 and $7 \mathrm{~A}$ ), thus excluding it from the border of the antorbital fenestra, as indicated by Brust et al. (2018) for UFSM 11505. The jugal being excluded from the antorbital fenestra or fossa is a condition shared with most aetosaurs, but not with some desmatosuchine aetosaurs (Small, 2002; Desojo and Báez, 2007), ornithosuchids (von Baczko and Desojo, 2016), and erpetosuchids (Maisch et al., 2013; Ezcurra et al., 2017; Lacerda et al., 2018).

Another shared feature between MCN-PV 2347 and UFSM 11505 is the presence of a marked ridge that runs longitudinally (confluent with the maxilla), dividing the main body of the jugal into laterodorsal and lateroventral faces (Figures 4 and 7A: $r$ ). This ridge is also present in phytosaurs (Stocker et al., 2017), gracilisuchids (e.g., MCZ 4117), paracrocodylomorphs (e.g., Prestosuchus chiniquensis Huene 1938; Mastrantonio et al., 2019; Dromicosuchus grallator Sues et al., 2003), erpetosuchids (e.g., Maisch et al., 2013; Ezcurra et al., 2017; Lacerda et al., 2018; Foffa et al., 2020), Acaenasuchus geoffroyi (see Marsh et al., 2020), and in several aetosaurs, such as Longosuchus meadei (TMM 31185-84), Desmatosuchus spurensis (UMMP V7476), Aetosaurus ferratus (SMNS 5770 S-16), Stenomyti huangae (according to Small and Martz, 2013), Coahomasuchus chathamensis (NCSM 23618), and Coahomasuchus kahleorum Heckert and Lucas, 1999 (NMMNH P18496). This ridge is not prominent in some aetosaurs, such as Paratypothorax andressorum (SMNS 19003; Schoch and Desojo, 2016) and Typothorax coccinarum (PEFO 38001; Reyes et al., 2021), and is absent in ornithosuchids (von Baczko and Desojo, 2016). The placement of this ridge may vary within Aetosauria, as in C. chathamensis (NCSM 23618), in which it is positioned at the level of the dorsal border of the posterior process, whereas in MCN-PV 2347 and in S. huangae (DMNH 60708 and 61394) it is situated in the middle portion of the posterior process.

The posterior process of the jugal is well preserved in MCN-PV 2347 (Figure 8) and in MCP3450-PV (Figure 9A and B), as an acute elongated process that has a round lateral surface. In MCNPV 2347, the posterior process of the jugal articu- lates dorsally with the quadratojugal and medially with the quadrate, thus forming the entire posteroventral border of the skull (Figures 3-4 and 7-8). This particular morphology has only previously been described in the small aetosaur Stenomyti huangae (according to Small and Martz, 2013), but here we recognize it as present in other aetosaurs as well, see Discussion.

On the latero-ventral face of the posterior process of the jugal in MCN-PV 2347 (Figures 4 and 7A and E: fo) and MCP-3450-PV (Figure 9B: fo), more than four foramina are arranged in a single line. They are concentrated at the level of the posterior border of the orbit, just ventral to the longitudinal ridge of the jugal in MCN-PV 2347 (Figures 4 and $7 \mathrm{~A}$ and $\mathrm{E}$ ), but are also present on the posterior process of the jugal in MCP-3450-PV (Figure $9 \mathrm{~A}$ and $\mathrm{B}$ ). Foramina on the jugal are also present in some ornithischian dinosaurs (e.g., Haya griva Makovicky et al., 2011; Norell and Barta, 2016), in shuvosaurids (e.g., Effigia okeeffeae Nesbitt and Norell, 2006; AMNH 30587), and in other aetosaurs (Aetosaurus ferratus, SMNS 5770 S-16; Coahomasuchus kahleorum, TMM 31100-437; Stenomyti huangae, DMNH 60708 and DMNH 61394; Paratypothorax andressorum, SMNS 19003; and Longosuchus meadei TMM 31185-84). They appear to be absent in the aetosaurine Coahomasuchus chathamensis (NCSM 23618) and in the desmatosuchines Desmatosuchus spurensis (UMMP V7476) and Desmatosuchus smalli (TTUP 9024), but better preserved materials are needed to confirm this. The jugal surface is devoid of the prominent ornamentation found in some aetosaurs (e.g., P. andressorum, SMNS 19003), Acaenasuchus geoffreyi (Marsh et al., 2020), and erpetosuchids (Ezcurra et al., 2017).

The jugal also has a posterior dorsal process that forms the anterodorsal border of the infratemporal fenestra (Figure 8B: pdpj). It is somewhat damaged on the right side of MCN-PV 2347 (Figure 7A and F), but better preserved on the left (Figure 8). The descending process of the postorbital was misidentified by Brust et al. (2018: figure 3C) as the dorsal process of the jugal, which is in fact preserved medially to it in UFSM 11505 . The posterior dorsal process articulates with the postorbital anteriorly, preventing it from contributing to the posteroventral margin of the orbit, a condition found in most aetosaurs (Desojo and Báez, 2007; Schoch and Desojo, 2016).

In ULBRAPV003T, the left jugal is somewhat broken anteriorly and posteriorly (Figure 9C-D). It is a gracile element similar to that of MCN-PV 2347 
A

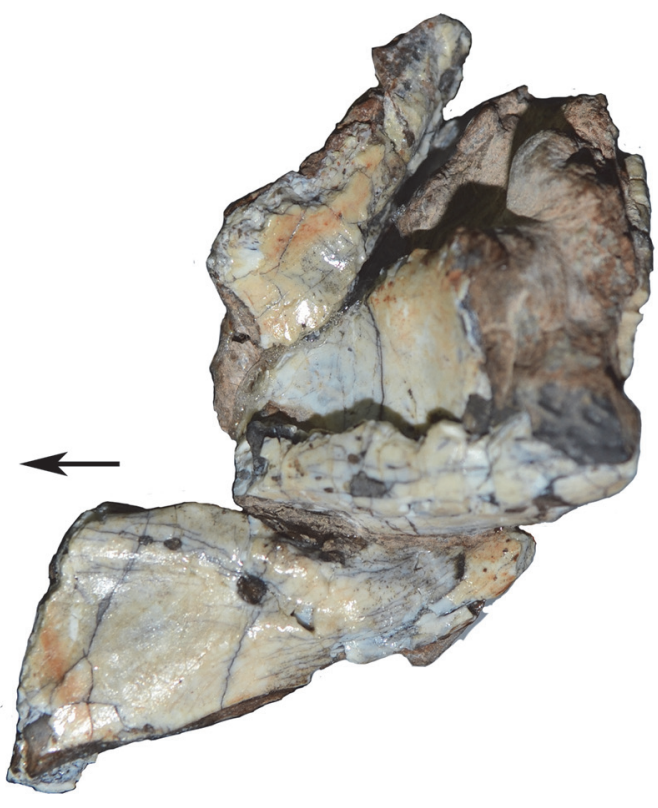

C

fo

0
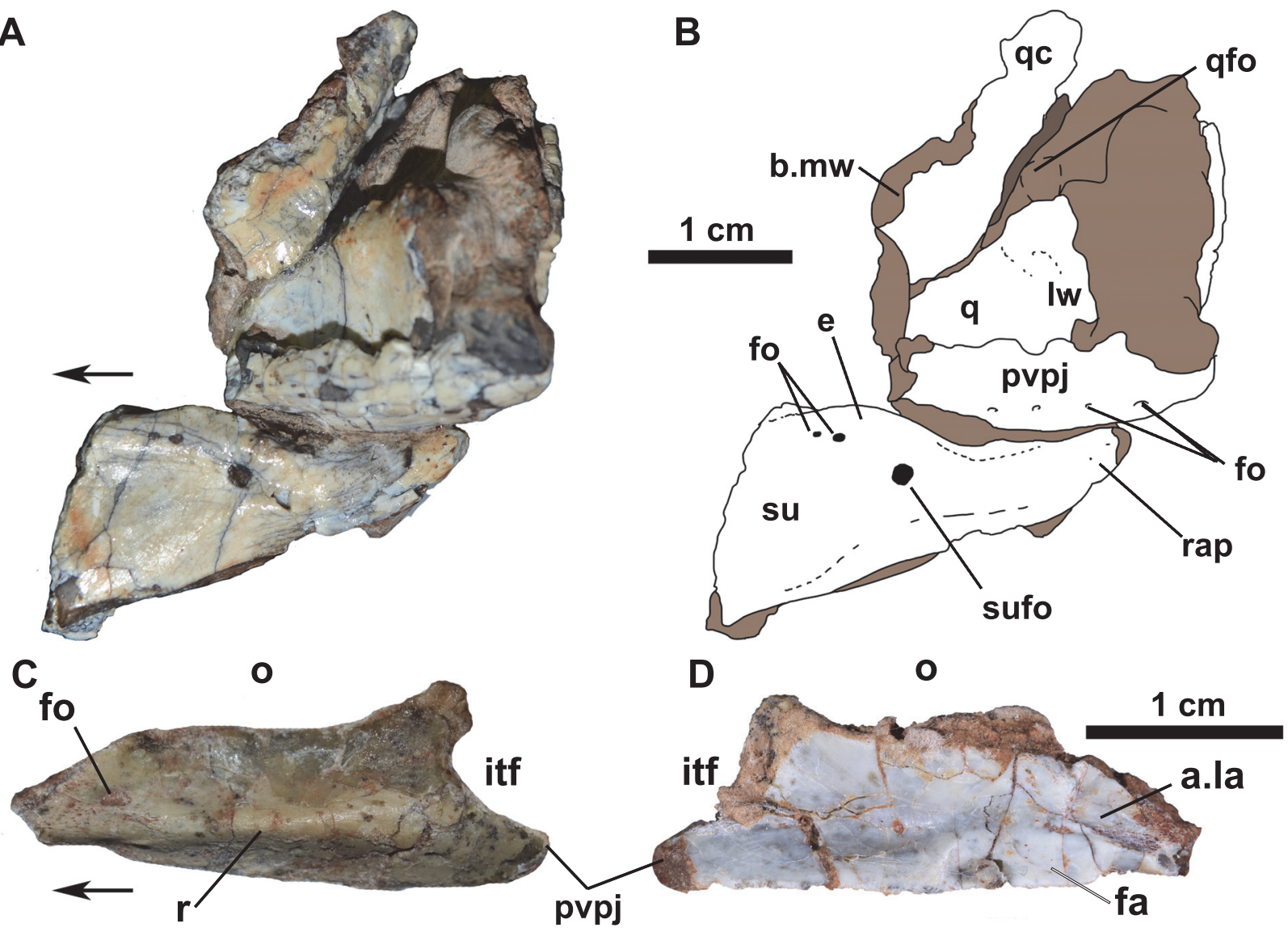

FIGURE 9. Fragments of the skull of MCP-3450-PV and right jugal of ULBRAPV003T. A, Photograph of the posterior process of the jugal of MCP-3450-PV in lateral view, also visible is the left surangular, in lateral view, and a fragmented left quadrate, in anterior view. $B$, interpretative drawing of MCP-3450-PV, matrix shown in brown. C, jugal of ULBRAPV003T in lateral view. D, jugal of ULBRAPV003T in medial view. Abbreviations: a.la, articulation with the lacrimal; b.mw, broken medial wing of the quadrate; e, elevation; fa, flat area; fo, foramen; qc, quadrate crest; qfo, quadrate foramen; itf, infratemporal fenestra; pvpj, posteroventral process of the jugal; Iw, lateral wing; o, orbit; r, ridge; rap, retroarticular process; su, surangular; sufo, surangular foramen.

and other aetosaurs, being anteroposteriorly elongate with a dorsal and a ventral posterior process (Figure 9C: pvpj). This process forms the anterior margin of the infratemporal fenestra (Figure 9C: itf). A lateral longitudinal ridge, more conspicuous than in MCN-PV 2347 and in UFSM 11505, is present (Figure 9C: r). Also, unlike in other Aetosauroides scagliai material, no visible foramina are present ventral to the longitudinal ridge of the jugal. Distinct from all other known aetosaurs, a large anterior foramen is present, dorsal to the longitudinal ridge (Figure 9C: $r$ ). Medial exposure of the jugal reveals the articular surface for the lacrimal (Figure 9D: a.la) and, ventrally, a medially-directed oval facet (Figure 9D: fa) not observed in MCN-PV 2347. These differences may be explained by intraspecific variation, and more specimens are needed to understand how ontogeny affects the morphology of the jugal in A. scagliai and in other aetosaurs.

Quadratojugal: In MCN-PV 2347, the quadratojugal resembles an inverted 'L' (Figures 3-4 and 7-8) articulating anterodorsally with the squamosal, ventrally with the posterior process of the jugal, and posteromedially with the quadrate. The quadratojugal does not contact the postorbital, being excluded by the contact of the squamosal with the jugal. This condition contrasts with that of some aetosaurine aetosaurs (Schoch, 2007; Schoch and Desojo, 2016) and Revueltosaurus callenderi (Parker et al., 2005) where the postorbital has a broad contact with the quadratojugal. The quadratojugal forms the posterior border of the infratemporal fenestra (Figure 8B: itf), and its posteromedial margin forms the lateral border of the quadrate foramen (Figure 7B: qfo). 


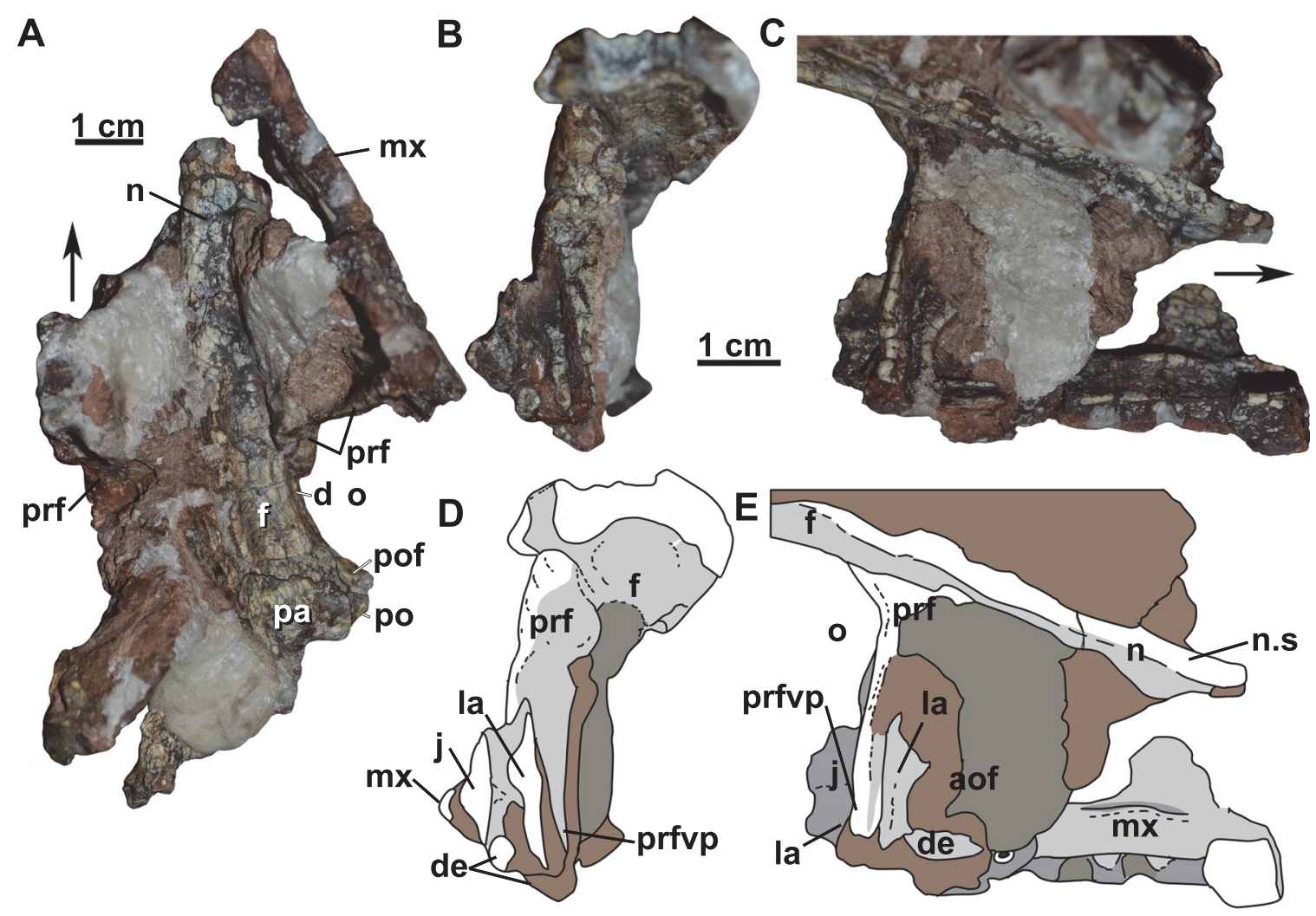

FIGURE 10. Inner surface of the partial skull of Aetosauroides scagliai (MCN-PV 2347). A, photograph in ventral view. $B$, anterior left orbital margin in posterior view. $C$, medial surface of the left side of the skull at the antorbital fenestra region. $\mathrm{D}$ and $\mathrm{E}$, interpretative drawings with polyethylene glycol resin in dark gray and matrix in brown. Abbreviations: aof, antorbital fenestra; d, depression; de, dentary; f, frontal; j, jugal; la, lacrimal; mx, maxilla; n, nasal; n.s, nasal suture; o, orbit; pa, parietal; prf, prefrontal; prfvp, prefrontal ventral process; po, postorbital; pof, postfrontal.

Both quadratojugals are preserved in $\mathrm{MCN}$ PV 2347, but only in the left one is it possible to observe the full extent of the anterior spike-like processes (Figure 8B: apqj) present in other aetosaurs, gracilisuchids (e.g., MCZ 4117; Butler et al., 2014), and phytosaurs (e.g., Stocker et al., 2017). This process is broken in the left quadratojugal, but its full extent can be seen in the natural cast on the rock (Figure 8B: nc). A depression is observed dorsal to the level of the quadrate foramen, being rimmed laterally by a ridge, which receives the lateral wing of the quadrate (Figure 8B-C: dqlw). The dorsal body of the quadratojugal is comparatively larger than those of Aetosaurus ferratus (SMNS 5770 S-16) and Stenomyti huangae (DMNH 60708), resembling more the size of the one present in Paratypothorax andressorum (SMNS 19003).

Lacrimal: In MCN-PV 2347, the lacrimal forms the dorsal and the posterior border of the antorbital fenestra and most of the antorbital fossa (Figure 3). The fossa is bounded by a faint ridge on the lacri- mal, which is not as prominent as the one on the maxilla. This ridge is less prominent than those of Aetosaurus ferratus (SMNS 5770 S-16) and Paratypothorax andressorum (SMNS 19003) in the same position. There is no ornamentation on the lacrimal of MCN-PV 2347, contrasting with $P$. andressorum (Schoch and Desojo, 2016) and Stagonolepis olenkae (Sulej, 2010). The anterior process contacts the ascending process of the maxilla anteriorly (Figure 3 ) and the nasal and prefrontal dorsally (Figures 2-3), as in other aetosaurs (Small, 2002; Schoch and Desojo, 2016).

The descending process of the lacrimal articulates posterodorsally with the prefrontal in lateral view (Figures 3-4; although slightly disarticulated on the left side) and medially with the ventral process of the prefrontal (Figure 10B-E: la). The contact of the lacrimal with the jugal and the maxilla is difficult to trace, as it is disarticulated on the left side of MCN-PV 2347 (Figure 10B and D). But, as also can be seen in UFSM 11505, the lacrimal seems to ventrally contact the jugal and the maxilla 
(Figure 3). The limits of these three bones in the $\mu C T$-scan of the right side of MCN-PV 2347 are difficult to reconstruct with confidence (Figure 7A and $7 \mathrm{~F}$ ), but they are consistent with the statements above. However, the ventral process of the lacrimal also seems to contact the jugal and the maxilla laterally (Figure 10D and 10E). Thus, the lacrimal in lateral view forms the anteroventral border of the orbit (as in other aetosaurs), excluding the jugal from the margin of the antorbital fenestra. As observed by Schoch (2007), most aetosaurs share this condition, with the lacrimal contacting both maxilla and jugal. This may also be true for Desmatosuchus smalli and Desmatosuchus spurensis (unlike the interpretation of Small, 2002), but the sutures of these bones are difficult to trace.

In MCN-PV 2347, at the end of the descending process of the lacrimal, the maxilla overlies the jugal in lateral view (Figure 7A). On the left side, it is also possible to observe that the ventral process of the prefrontal lays medial to the descending process of the lacrimal (Figure 10C-D: prfvp). The ventral process of the lacrimal contacts the medial surface of the jugal (Figure 7F) and is covered medially by the ventral process of the prefrontal. This morphology differs from that interpreted by Walker (1961) for Stagonolepis robertsoni (based on the specimens NMS R4790 and R4787), in which the jugal overlies both the maxilla and lacrimal. The lacrimal foramen (lacrimal duct) is not observed in MCN-PV 2347, nor are any other foramina or sculpturing, unlike Typothorax coccinarum (Reyes et al., 2021).

Prefrontal: As in other aetosaurs, the prefrontal of MCN-PV 2347 is a triangular element, forming the anterodorsal margin of the orbit in lateral view. Anteriorly, it articulates dorsomedially with the nasal, ventrally with the lacrimal and posterodorsally with the frontal. The anterior process of the prefrontal presents an acute anterior tip extending toward the anterior third of the antorbital fenestra in A. scagliai, similar to that of other aetosaurs, such as Stagonolepis olenkae (Sulej, 2010), Aetosaurus ferratus, and Paratypothorax andressorum (Schoch and Desojo, 2016).

The anterior process of the prefrontal of Aetosauroides scagliai almost reaches the mid-length of the antorbital fenestra (Figures 3 and 4), as in Paratypothorax andressorum (SMNS 19003; Schoch and Desojo, 2016), but contrasts with the elongated prefrontal of Stenomyti huangae (Small and Martz, 2013), which extends far anterior to the antorbital fenestra. In MCN-PV 2347 the anterior process curves gently ventrally and is contacted by the nasal and the lacrimal. On the left side, the articular surface of the contact with the lacrimal is exposed, and is delimited dorsally by a ridge. As in most other aetosaurs, the dorsal contribution of the prefrontal to the skull roof is minimal, contrasting with the unusual condition of $S$. huangae (DMNH 60708; Small and Martz, 2013) where it is comparatively more medially and anteriorly expanded. The left prefrontal bears two foramina (Figures 3 and 4: fo), one near the mid-length, similar in position to another A. scagliai specimen (UFSM 11505), Aetosaurus ferratus (SMNS 5770 S-18), and resembling the foramina in the putative first palpebral of S. huangae (Small and Martz, 2013). Another foramen is present near the suture between the prefrontal and the lacrimal (Figure 3: fo), which is also present in S. huangae (DMNH 60708).

The ventral process of the prefrontal forms, in medial view, an acute straight projection that extends ventrally, along the inner surface of the lacrimal, to the ventral level of the jugal (Figure 10: prfvp). This ventral process is generally thin in MCN-PV 2347, but lateromedially expanded ventrally, almost forming a ridge. The dorsal posterior process is medially projected at the anterodorsal margin of the orbit (Figure 10). This morphology is similar to that of Stagonolepis robertsoni (Walker, 1961) and Stagonolepis olenkae (Sulej, 2010). As indicated by Witmer (1997) for Longosuchus meadei, the prefrontal may have formed the lateral wall of the postnasal fenestra and the anteromedial rim of the orbit. There is no palpebral preserved in MCN-PV 2347, only a depression between the posterior and the ventral process of the prefrontal, which may indicate its articular facet (see Discussion).

Frontal: The frontal is a rectangular element in MCN-PV 2347 that forms most of the dorsal margin of the orbit, being half the anteroposterior length of the nasal (see Table 3), like other aetosaurs (e.g., Walker, 1961; Schoch and Desojo, 2016). The anterior contact of the frontal with the nasal is at the level of the anterior end of the prefrontal. The frontal also contacts the prefrontal laterally, the parietal posteriorly, and the postfrontal posterolaterally, as occurs in most aetosaurs (e.g., Parker, 2016a; Schoch and Desojo, 2016). As in Stagonolepis robertsoni (Sulej, 2010), the frontal is anteroposteriorly straight in lateral view in MCN-PV 2347.

In dorsal view (Figure 2), the frontal shows a medial region that is more elevated and surrounded laterally by a sinuous groove (Figure 3: $\mathrm{lg}$ ), as occurs in other aetosaurs (Sulej, 2010; Schoch and Desojo, 2016; Parker, 2016a), includ- 

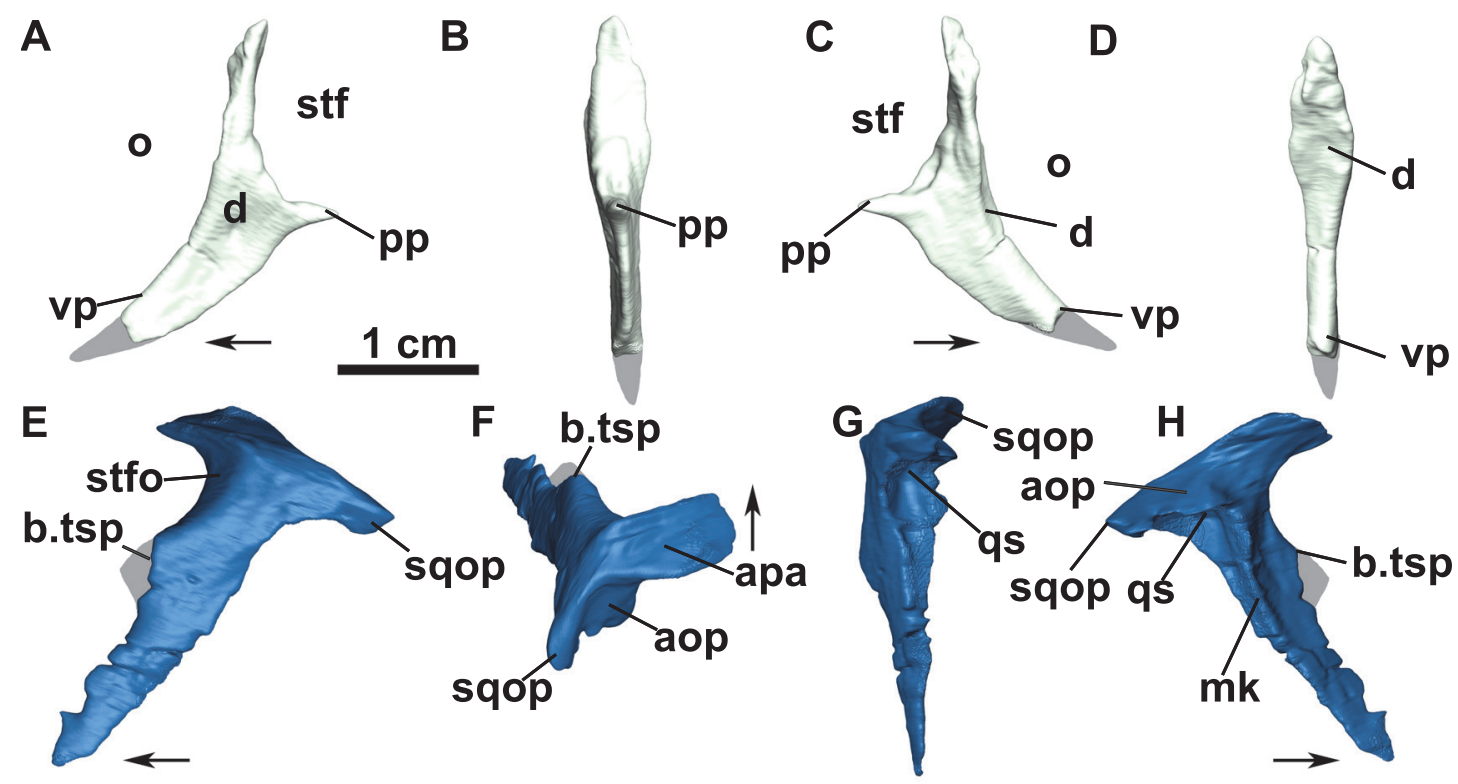

FIGURE 11. Three-deminsional reconstruction based on $\mu$ CT-scan images of the left postorbital (A-D) and squamosal (E-H) of Aetosauroides scagliai (MCN-PV 2347) in lateral (A and E), posterior (B), medial (C and H), anterior (D), poserodorsal (F) and ventral (G) views. Abbreviations: aop, articulation surface for the otoccipital; apa, articulation surface of the parietal; b.tsp, triangular spur; d, depression; mk, medial keel; o, orbit; pp, posterior process; qs, quadrate socket; sqop, occipital process; stf, supratemporal fenestra; stfo, supratemporal fossa; vp, ventral process. Gray areas indicate missing portions.

ing other skulls of Aetosauroides scagliai (PVL 2052, PVL 2059 and UFSM 11505; Brust et al., 2018). This groove is limited laterally by a raised, ornamented margin of the frontal that is elevated above the rest of the bone (Figure 3: for) as in other A. scagliai (PVL 2059 and UFSM 11505). This contrasts with the condition in Scutarx deltatylus (PEFO 34616) and Paratypothorax andressorum (SMNS 19003), in which the orbital margin is at the same level as the rest of the main frontal body. Ornamentation is also evident on the dorsal surface of the frontals (Figure 2), mostly around the orbital region, where pits and grooves form ridges radiating from the posterior center of the bone. This condition is similar to that of proterochampsids (e.g., Trotteyn and Ezcurra, 2014), although these ridges are less prominent and more sinuous in $A$. scagliai. In contrast to other aetosaurs, the anterior region of the frontal is less ornamented (Walker, 1961; Sulej, 2010), showing more grooves than pits.

Postfrontal: The postfrontal forms the posterodorsal corner of the orbit in MCN-PV 2347 (Figure 2: pof). It is a small, triangular element (see Table 3 ) that articulates laterally with the parietal, posteriorly with the postorbital, and dorsomedially with the frontal, preventing it from contacting the dorsal process of the postorbital. The dorsal surface of the postfrontal is nearly flat, contrasting with the depressed areas of Aetosaurus ferratus (SMNS 5770 S-16) and Stenomyti huangae (DMNH 60708). Ventrally, a depression is present along the suture of the postfrontal with the frontal, parietal, and postorbital.

Postorbital: The postorbital is a thin, inverted ' $T$ 'shaped bone (Figures 3, 8A, and 11A-D) making up almost all of the postorbital bar and the anteroventral border of the supratemporal fenestra. Its dorsal process articulates with the postfrontal anteriorly and with the parietal medially (Figure 3 ). The posterior process is short and acute (Figures 11A and $7 \mathrm{C}$ ) and overlaps the squamosal posteroventrally (Figure 3), together with most of the ventral margin of the postorbital. The ventral process of the postfrontal is broad and long, and articulates with the posterodorsal process of the jugal (Figure $8 \mathrm{~A}$ and $8 \mathrm{~B}$ ). As observed in UFSM 11505, the ventral process in MCN-PV 2347 almost reaches the lower margin of the orbit. As in most aetosaurs, the postorbital does not contact the quadratojugal because of the contact between the jugal and the squamosal (see Reyes et al., 2021). A depression is observed in the orbital rim of the postorbital and in the lateral surface of its main body (Figure 11CD: d), resembling that of Paratypothorax andresso- 
rum (SMNS 19003) and Stenomyti huangae (DMNH 60708).

Squamosal: In MCN-PV 2347, the squamosal is a dorsoventrally elongate bone that forms the posterodorsal corner of the skull (Figures 3 and 11EF). It forms, as in other aetosaurs, the posterior border of the supratemporal fenestra, with the anterior portion presenting a short, anteriorly projected triangular spur (as in Scutarx deltatylus, PEFO 34616), which is broken in MCN-PV 2347 (11E: b.tsp). In life, the spur would have been overlapped by the posterior process of the postorbital (disarticulated in MCN-PV 2347). Dorsal to this structure, the main portion of the squamosal that borders the supratemporal fenestra is anteriorly concave, creating a shallow supratemporal fossa (Figure 11E: stfo). This fossa is present in other aetosaurs, but is more triangular in Paratypothorax andressorum (SMNS 19003), Stenomyti huangae (DMNH 60708), and Coahomasuchus chathamensis (NCSM 23618). The main body of the squamosal of MCN-PV 2347 is slender compared with most other aetosaurs, although resembling the condition in C. chathamensis (NCSM 23618).

A ventral lobe of the squamosal projects anteroventrally from the anterior triangular spur, and is very thin latero-medially and acute laterally (Figure 11E). This acute morphology is similar to that of Scutarx deltatylus (PEFO 34616), but differs from that of Stenomyti huangae (DMNH 61392) in which the ventral lobe is expanded distally. The shape of the ventral lobe is unknown in other aetosaurs, as it is either broken (Stagonolepis olenkae, Sulej, 2010; Longosuchus meadei, TMM 3118598) or overlapped by the postorbital (Desmatosuchus smalli, TTUP-9023) in most specimens. The ventral lobe contacts the jugal ventrally and the quadratojugal posteriorly, thus preventing the squamosal from participating in the infratemporal fenestra margin (Figures 3 and $8 A-B$ ). This arrangement is similar to that of $S$. huangae (Small and Martz, 2013), but contrasts with that of other aetosaurs, like D. smalli (TTUP-9023), Aetosaurus ferratus (Schoch, 2007), and Paratypothorax andressorum (SMNS 19003), where the squamosal does not contact the jugal because of its articulation with the postorbital. The squamosal also contacts the parietal dorsomedially, where it presents a marked medial keel (Figure 11H: mk).

As in other aetosaurs, the posterior occipital process of the squamosal in MCN-PV 2347 (Figures 3 and 11E: sqop) is slightly hooked ventrally (forming the 'paraoccipital process' of Desojo and Báez, 2007 and the 'squamosal horn' of Small and
Martz, 2013). This structure is not as thickened or rugose as that of Stagonolepis olenkae (Sulej, 2010), Scutarx deltatylus (PEFO 34616), Stenomyti huangae (DMNH 60708), or Aetosaurus ferratus (SMNS 5770 S-16), and more closely resembles the condition in Coahomasuchus chathamensis (NCSM 23618, although shorter). Dorsally, a depressed area of the squamosal is present, corresponding to the facet where the paraoccipital process of the opisthotic articulates (Figure 11F: aop). Ventral to the occipital process of the squamosal, a circular socket (= otic articulation of Holliday and Witmer, 2008) receives the proximal head of the quadrate.

Quadrate: In MCN-PV 2347 the left quadrate is complete (Figures $8 \mathrm{~A}$ and 12, Table 4), but the right one is broken at its proximal end (Figure 7B). The quadrate in MCP-3450-PV is exposed in anterior view (Figure 9A and B; Table 4), broken at the quadrate head. It is a triradiate element consistent with the previously known morphology in Aetosauroides scagliai (UFSM 11505; Brust et al., 2018) and other aetosaurs, with a robust condyle situated on the ventral ramus. In describing the Argentinian A. scagliai material, Casamiquela (1961) identified a pair of 'problematic' elements (probably lost) interpreted as pertaining to the surangulars. We consider these elements to represent both quadrates of PVL 2059, as they are consistent with the morphology described here. The condyle of MCNPV 2347 and MCP-3450-PV has a 'figure eight' shape in occlusal view (Figure 12F), with the medial region larger than the lateral one, as in $D$. smalli (TTUP-9420). The quadrate head is thick and globular (Figure 12E) and fits into the squamosal socket, contacting the medial keel of the squamosal dorsally. From the main body, a large medial wing projects anteromedially at an obtuse angle relative to the condyle (Figure 12B), slightly ventral to the level of the quadrate foramen (Figure 12C).

A somewhat sub-rectangular lateral wing of the quadrate projects antero-laterally from the condyle toward the quadrate head (Figure 12: Iw). This morphology is consistent with that of Aetosauroides scagliai (UFSM 11505), Stagonolepis robertsoni (MCZD 2-4), and most other aetosaurs, also presenting the socket for the quadratojugal as observed in Stagonolepis olenkae (ZPAL Ab III 2376; Sulej, 2010) and Desmatosuchus smalli (TTUP 9420). At the middle of the element, the lateral wing is pierced by the medial margin of the quadrate foramen (Figure 12A: qfo). This morphology is observable in both specimens, as well as in UFSM 11505 (contra Brust et al., 2018). Thus, the 


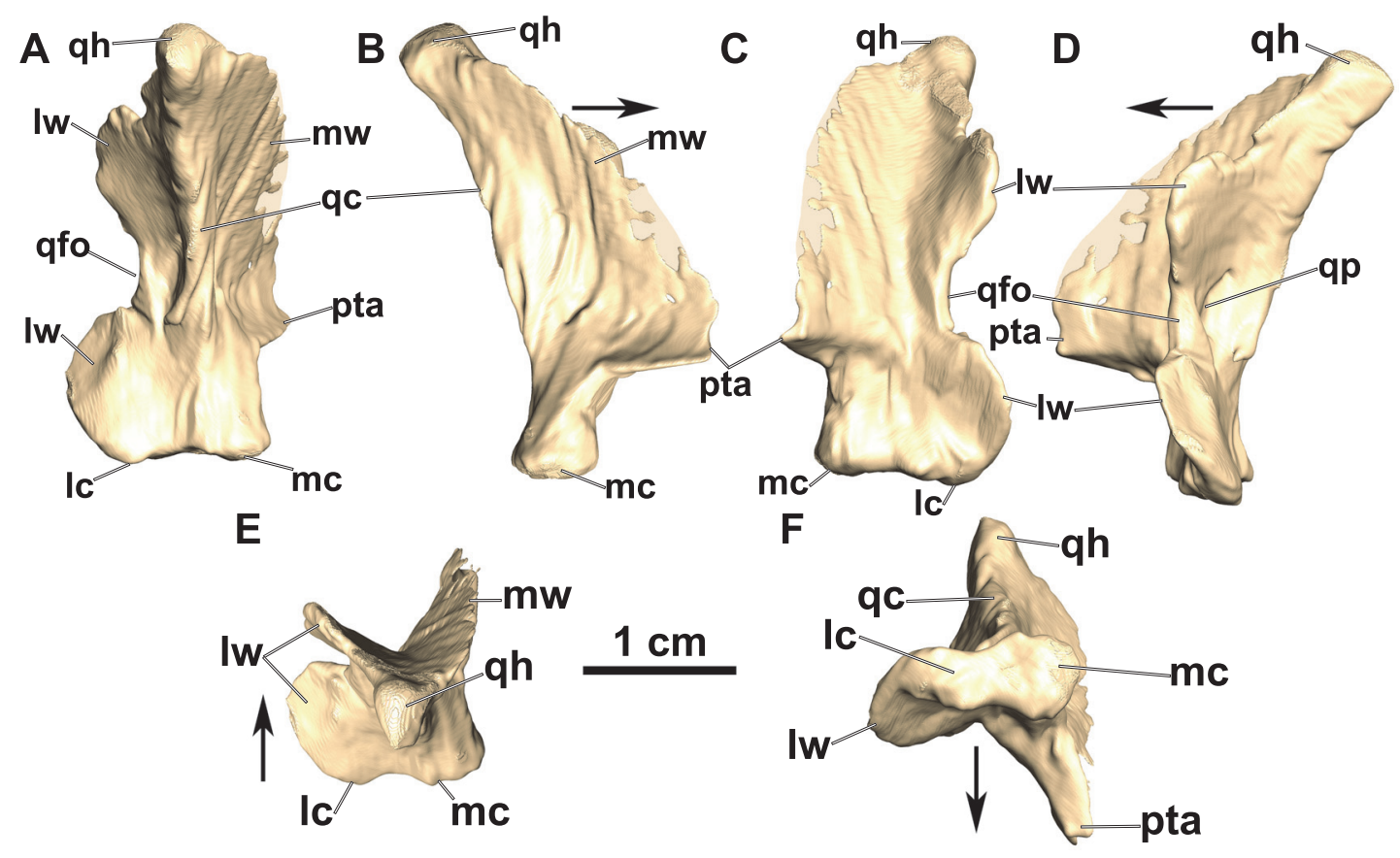

FIGURE 12. 3D Reconstruction based on $\mu \mathrm{CT}$-scan images of the left quadrate of Aetosauroides scagliai (MCN-PV 2347). A, posterior view; $B$, medial view; $C$, anterior view; $D$, lateral view; $E$, dorsal view; $F$, ventral view. Abbreviations: Ic, lateral condyle; Iw, lateral wing; mc, medial condyle; mw, medial wing; pta, pterygoid articulation; qc, quadrate crest; qfo, quadrate foramen; qh, quadrate head; qp, quadrate pit; pta, pterygoid articulation.

quadrate foramen is situated between the quadratojugal and the quadrate lateral wing, as in most other aetosaurs (e.g., Small, 2002; Sulej, 2010; Schoch and Desojo, 2016) and other pseudosuchians (e.g., Gracilisuchus stipanicicorum, MCZ 4117; Romer, 1972; Riojasuchus tenuisceps Bonaparte, 1969; von Baczko and Desojo, 2016).

A pit posterior to the quadrate foramen in the lateral wing has been described for Stagonolepis robertsoni (Walker, 1961) and Stagonolepis olenkae (Sulej, 2010) and is also preserved in MCN-PV 2347 (Figure 12D: qp) and UFSM 11505 (Brust et al., 2018, figure 5; not preserved in MCP-3450$\mathrm{PV})$. This pit is also visible in other aetosaurs, like Stenomyti huangae (DMNH 60708) and Longosuchus meadei (TMM 31185-84), but seems to be absent in Desmatosuchus smalli (TTUP 9024), where only a slight depression is present. Heckert

TABLE 4. Comparative measurements of the quadrate of Aetosauroides scagliai specimens MCN-PV 2347 (left element) and MCP-3450-PV.

\begin{tabular}{lcc}
\hline & MCN-PV 2347 & MCP-3450-PV left \\
\hline Height & 37.5 & - \\
Condyle width & $\sim 13.2$ & 13.0 \\
Condyle length & 7.0 & 6.2 \\
\hline
\end{tabular}

et al. (2017) were unable to identify the quadrate foramen in Coahomasuchus chathamensis. A careful inspection of the type material (NCSM 23618) revealed the presence of a deep pit on the lateral wing and a semi-circular hole on its lateral border, which we interpret as the quadrate foramen.

Parietal: The parietals are better preserved in MCN-PV 2347 (Figures 3 and 13A) than in MCP3450-PV (Figure 13B). Their morphology is consistent with that known previously for Aetosauroides scagliai (PVL 2059, UFSM 11505 and also ULBRAPV003T; Figure 13C) and other aetosaurs. Like other aetosaurs, the parietals in MCN-PV 2347 and MCP-3450-PV exhibit a quadrangular shape in dorsal view, contacting the frontal anteriorly, the postorbital and postfrontal laterally, the supraoccipital ventromedially, and the squamosal and opisthotic ventrolaterally. This morphology contrasts with the proximate outgroups of Aetosauria, such as Revueltosaurus callenderi (see Parker et al., 2005), Acaenasuchus geoffreyi (see Marsh et al., 2020), and erpetosuchids (e.g., Lacerda et al., 2018), in which the width of the parietal is extremely reduced between the supratemporal fenestrae.

In dorsal view, the parietal bears a prominent transversal crest, dividing it into an anterior region 


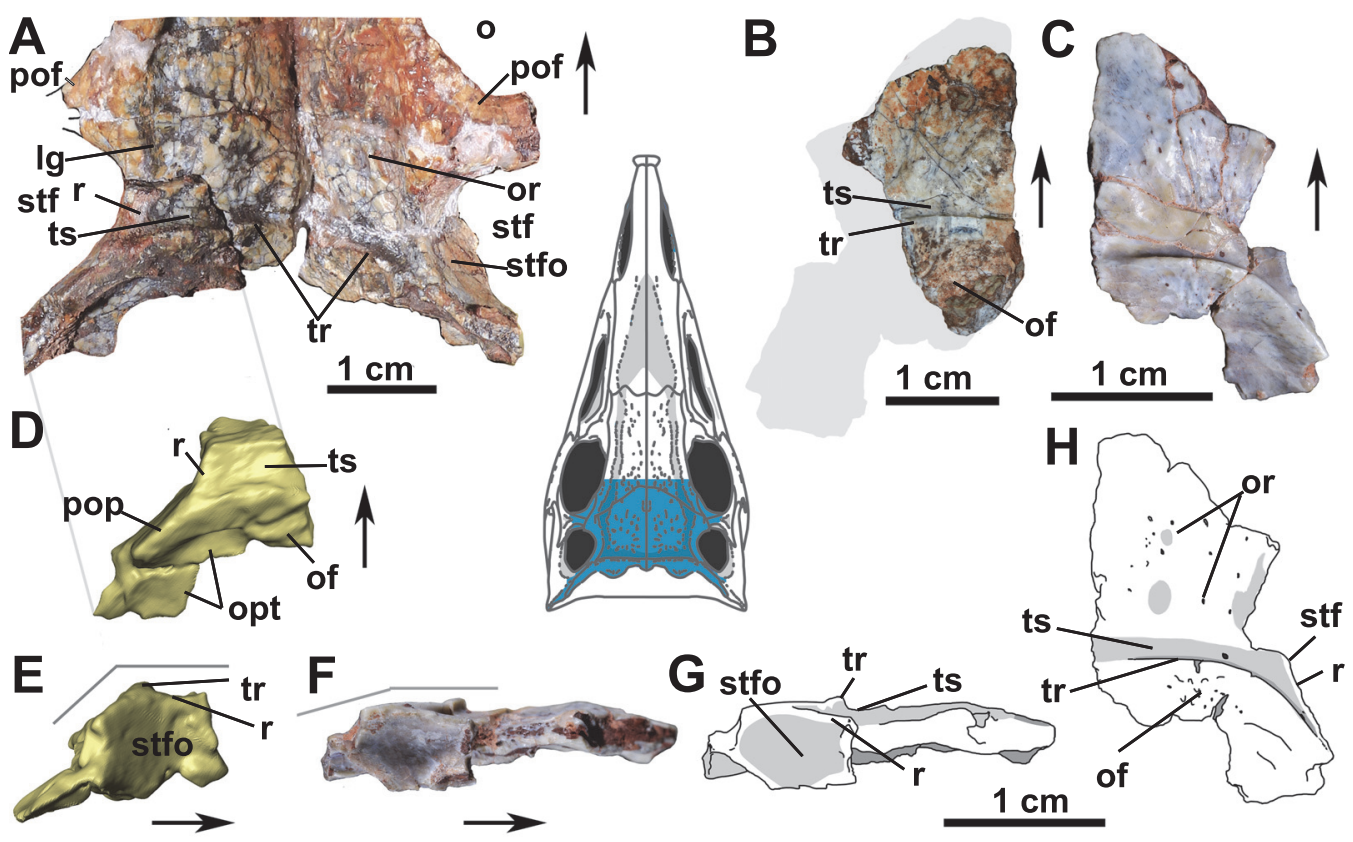

FIGURE 13. Parietal of Aetosauroides scagliai, MCN-PV 2347 (A, D and E) and MCP-3450-PV (B); and 'Polesinesuchus aurelioi' (ULBRAPV003T; C, F, G and H). A, photograph of posterior region of the skull of MCN-PV 2347 in dorsal view. B, photograph of the left parietal of MCP-3450-PV in dorsal view. C, photograph of the right parietal of ' $P$. aurelioi' in dorsal view. $D, 3 D$ reconstruction based on $\mu$ CT-scan images of a fragment of the left parietal of MCN-PV 2347 in dorsal view. E, 3D reconstruction based on $\mu$ CT-scan images of a fragment of the left parietal of MCN-PV 2347 in lateral view (mirrored). $\mathrm{F}$, photograph of the right parietal of ' $P$. aurelioi' in lateral view. $\mathrm{G}$, interpretative drawing of the right parietal of ' $P$. aurelioi' in lateral view. $\mathrm{H}$, interpretative drawing of the right parietal of ' $P$. aurelioi' in dorsal view. The gray lines in $\mathrm{E}$ and $\mathrm{F}$ depict the inclination angle of the occipital portion of the parietal. Abbreviations: Ig, lateral groove; o, orbit; of, overhanging flange; opt, occipital portion of the parietal. or, ornamentation; pof, postfrontal; pop, paraoccipital process of the parietal; r, ridge; stfo, supratemporal fossa; tr, transverse ridge; ts, transverse sulcus.

and an anteriorly inclined occipital region, as occurs in other aetosaurs (Walker, 1961; Heckert and Lucas, 1999; Nesbitt, 2011) and ornithosuchids (von Baczko and Desojo, 2016). The surface of the anterior region preserves an ornamented dorsal surface consisting of deep pits and grooves, separated by ridges. The ornamentation is less marked in MCP-3450-PV (Figure 13B: or) and is even fainter in ULBRAPV003T (Figure 13F: or) and Aetosaurus ferratus (SMNS 5770 S18 and SMNS 5770 S-21). There is no distinctive sagittal dorsal ridge as in Stenomyti huangae (DMNH 60708 and 61392) or any prominent elevated region like the bosses of Longosuchus meadei (TTM 31185-84 and 31185-98) and both Desmatosuchus species (TTUP 9023 and UCMP 27408). The dorsal roof formed by the parietals in MCN-PV 2347 and MCP-3450-PV is broad, as in other aetosaurs and in ornithosuchids (von Baczko and Desojo, 2016), contrasting with the constricted condition in loricatans (Sues et al., 2013; Mastrantonio et al., 2019), gracilisuchids (e.g., Lecuona,
2012), and erpetosuchids (Maisch et al., 2013; Ezcurra et al., 2017; Lacerda et al., 2018).

In MCN-PV 2347, as in most aetosaurs, a deep groove on the lateral side of the dorsal surface of the frontal continues onto the parietal (Figure 13A: lg), flanking the margin of the supratemporal fenestra. This lateral groove fuses with a deep transverse sulcus (parietal sulcus of Parker, 2005) situated on the mid-region of the parietal (Figure 13A-C: ts), which separates the anterior region of this bone from the occipital region in most aetosaurs (see Parker, 2005). The transverse sulcus of MCN-PV 2347 does not contact the supratemporal fenestra, which is delimited dorsally by a faint ridge connected to the raised anterior border of the occipital region of the parietal in a ' $V$ '-shaped structure (Figures 2 and $13 \mathrm{~A}$ and 13D: r). This condition is shared only with Stegomus arcuatus (YPM-PU 21750), Aetosaurus ferratus (SMNS 5770 S-18 and SMNS 5770 S-21), and with other Aetosauroides scagliai specimens (PVL 2059, UFSM 11505, and ULBRAPVT003). 
Although the transverse sulcus is preserved in MCP-3450-PV, its lateral limits are broken.

The dorsal border of the occipital region in MCN-PV 2347 and MCP-3450-PV is delimited by a raised transverse ridge, just posterior to the transverse sulcus (Figure 13A: tr), with a semicircular contour in dorsal view when observing both parietals. This condition is similar to other Aetosauroides scagliai specimens (PVL 2059, UFSM 11505, and ULBRAPV003T) and to Paratypothorax andressorum (Schoch and Desojo, 2016), but in $A$. scagliai it is continuous across both parietals (whereas it is separated in $P$. andressorum; SMNS 19003). Over this ridge, several rugosities are observed, which are especially concentrated on the thick, overhanging flange (Figure 13A: of). This overhanging flange is characteristic of aetosaurs and supports the first dorsal paramedian or nuchal osteoderms (Walker, 1961; Desojo and Báez, 2007; Reyes et al., 2021). In MCN-PV 2347, the overhanging flanges are postero-ventrally oriented and not projected, similar to the condition of other A. scagliai (MCP-3450-PV and ULBRAPV003T; Figure 13B, C and F: of), Stagonolepis robertsoni (MCZD 2-4), Stagonolepis olenkae (ZPAL AbIII 2722; Sulej, 2010), and P. andressorum (SMNS 19003). This contrasts with Desmatosuchus spurensis (UMMP V7476), Longosuchus meadei (TMM 31185-84 and 31185-98), and cf. Lucasuchus hunti Long and Murry, 1995 (TMM 31100531), where the flanges are posteriorly projected. Unlike in P. andressorum (Schoch and Desojo, 2016), a slight elevation does not support the flanges ventrally in A. scagliai (MCN-PV 2347 and ULBRAPV003T).

In MCN-PV 2347, the occipital portion of the parietal is anteriorly inclined at more than $30^{\circ}$ relative to the anterior region (Figure 13E). This condition is similar to most aetosaurs, but differs from the immature Aetosauroides scagliai specimen ULBRAPV003T (Figure 13F), in which the occipital region is poorly inclined like other small-sized aetosaur individuals (e.g., Stenomyti huangae isolated parietals, DMNH 45882 and DMNH 55070; and some Aetosaurus ferratus, SMNS 5770 S-18 and SMNS 5770 S-21), suggesting it may be ontogenetically related.

The occipital lateral expansion contacts the squamosal laterally, forming the posterior border of the round supratemporal fenestra in MCN-PV 2347 (Figures 3 and 13A: stf) and ULBRAPV003T (Figure $13 \mathrm{C}$ and $\mathrm{F}$ : stf). A round supratemporal fenestra is shared with most other aetosaurs, but contrasts with the triangular shape in Paratypotho- rax andressorum (as indicated by Schoch and Desojo, 2016; SMNS 19003). As in most aetosaurs (Figure 3: stfo) and Revueltosaurus callenderi (Nesbitt, 2011), a deep supratemporal fossa is present medially in the occipital lateral expansion of MCN-PV 2347 and ULBRAPV003T. However, they lack a groove on the anterior surface, which is present in Desmatosuchus spurensis (e.g., UCMP 27408, UMMP 7476, and GPIT-PV-108053) and Stagonolepis olenkae (ZPAL AbIll 466/17). In MCN-PV 2347, the parietal articulates with the otooccipital ventrally, probably forming the dorsal border of the post-temporal fenestra, as occurs in all other aetosaurs.

Pterygoid: We find no evidence of preservation of the vomer, palatine, or ectopterygoid in MCN-PV 2347 , thus the palate is represented solely by the pterygoids, of which the left one is better preserved (Figure 14). The pterygoid is a triradiate laminar bone, with an elongated anterior process (palatal processs or ramus) that contacts its counterpart medially and forms the medial margin of the choana. The lateral wing is broken, but it would have contacted the ectopterygoid to form the suborbital fenestra (Figure 14A: ectc). The quadrate process (or ramus) of the pterygoid and the contact with the basipterygoid process are broken.

There are no teeth on the ventral surface of the pterygoid, but two ridges are visible concealing a depressed area in the middle region of the bone (Figure 14C: r). The pterygoid of MCN-PV 2347 is very similar to that of Neoaetosauroides engaeus (Desojo and Báez, 2007) and Desmatosuchus smalli (Small, 2002), being highly elongate in comparison to other aetosaurs, like Stagonolepis olenkae (Sulej, 2010) and Aetosaurus ferratus (Schoch, 2007), in which the lateral wing is broader and laterally projected. Further information on the palatine of aetosaurs is needed to address whether a lateral contact with the anterior process of the pterygoid is the typical condition for the group, as indicated by most other authors (Walker, 1964; Schoch, 2007; Desojo and Baez, 2007; Sulej, 2010), or whether the pterygoid contributed more to the posteromedial end of the choana, as interpreted by Small (2002) for Desmatosuchus smalli. Mandible. The mandible of MCN-PV 2347 is only partially preserved, missing the coronoid (although this element is possibly absent in aetosaurs and phytosaurs), splenial, and the posterior portion of the dentary. In MCP-3450-PV, only the retroarticular process of the surangular and a fragment of the prearticular are present (Table 5). 


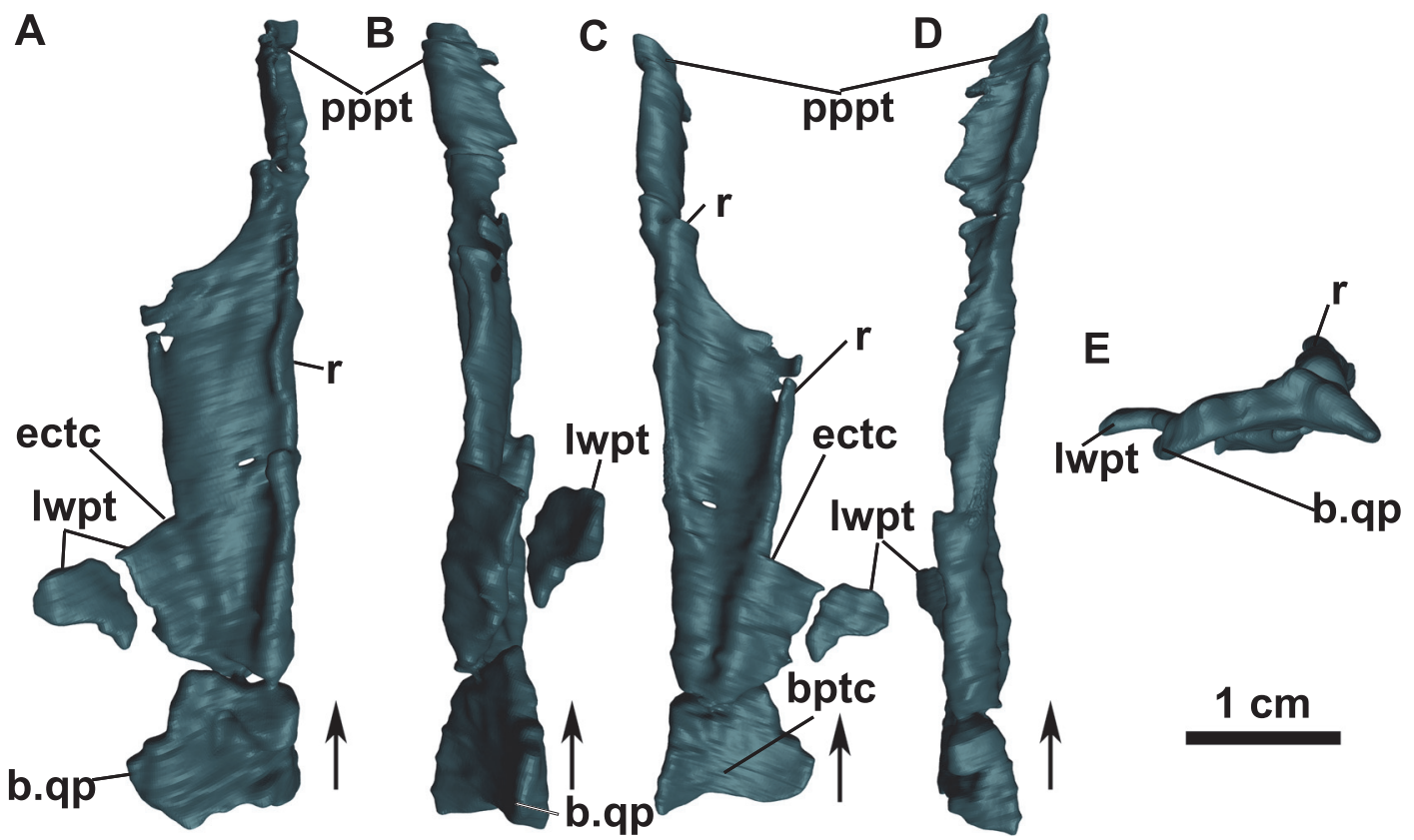

FIGURE 14. 3D Reconstruction based on $\mu$ CT-scan images of the left pterygoid of Aetosauroides scagliai (MCN-PV 2347). A, dorsal view. B, lateral view. C, ventral view. D, medial view. E, posterior view. Abbreviations: b.qc, broken quadrate contact; bptc, basipterygoid process contact; ectc, ectopterygoid contact; Iwpt, lateral wing of the pterygoid; pppt, palatal process of the pterygoid; r, ridge.

Dentary: In MCN-PV 2347 both dentaries are partially preserved, including the anterior tip of the left and the mid-region of the right (Figure 15). The dentary is slightly bowed laterally posterior to the symphyseal region, giving the mandible the 'V'shaped morphology typical for aetosaurs. As in other Aetosauroides scagliai specimens (PVL 2059 and UFSM 11505; Casamiquela, 1961; Brust et al., 2018), it exhibits an anteroposteriorly straight and slender morphology with a slightly convex ventral margin. This distinguishes $A$. scagliai from almost all other aetosaurs, which share a sharp dorsal inflexion (Desojo and Ezcurra, 2011; Parker, 2018), the 'chin' shape of Walker (1961). The single exception would be the aetosaurine Typothorax coccinarum (Hunt et al., 1993; Martz, 2002; Reyes

TABLE 5. Measurements of the mandible of Aetosauroides scagliai specimen MCN-PV 2347, in mm.

\begin{tabular}{lc}
\hline Dentary height at mid length & 31.4 \\
Mandibular fenestra height & 12.4 \\
Mandibular fenestra length & 37.1 \\
Retroarticular process from posterior & 31.1 \\
border of mandibular fenestra & \\
Surangular maximum height & 12.7 \\
Surangular maximum length & $\sim 64.6$ \\
\hline
\end{tabular}

et al., 2021), in which the dentary is also slender, but less anteroposteriorly straight.

The anterior tip of the dentary of MCN-PV 2347 is acute in lateral view (Figures 4 and 15A-B) with an edentulous region marked by a laterally expanded dorsal shelf anterior to the first dentary teeth as in other aetosaurs (see Parker, 2018). This morphology is only visible in $\mu$ CT-scan images of MCN-PV 2347, as the tip of the left mandible is stuck to the palatal region of the rostrum and is badly preserved in other Aetosauroides scagliai specimens (PVL 2059 and UFSM 11505). The anteriormost tip preserves small striations not observed posteriorly, as in Desmatosuchus smalli (TTUP 9024).

A large, deep elliptical foramen is present in both dentary rami (broken in the right dentary) below the dorsal shelf (Figure 15A: afo). It is preceded anteriorly by a shallow groove that runs toward the anterior tip, but does not reach it. The same structure is observed in other Aetosauroides scagliai specimens (PVL 2052, PVL 2059, and UFSM 11505) and in Paratypothorax andressorum (SMNS 19003; Schoch and Desojo, 2016). In other aetosaurs, like Stenomyti huangae (DMNH 60708), Stagonolepis robertsoni (Walker, 1961; Small, 2002), Stagonolepis olenkae (ZPAL Ablll 573; Sulej, 2010), Desmatosuchus smalli (TTUP 9024; Small, 2002), and Longosuchus meadei (TTUP 

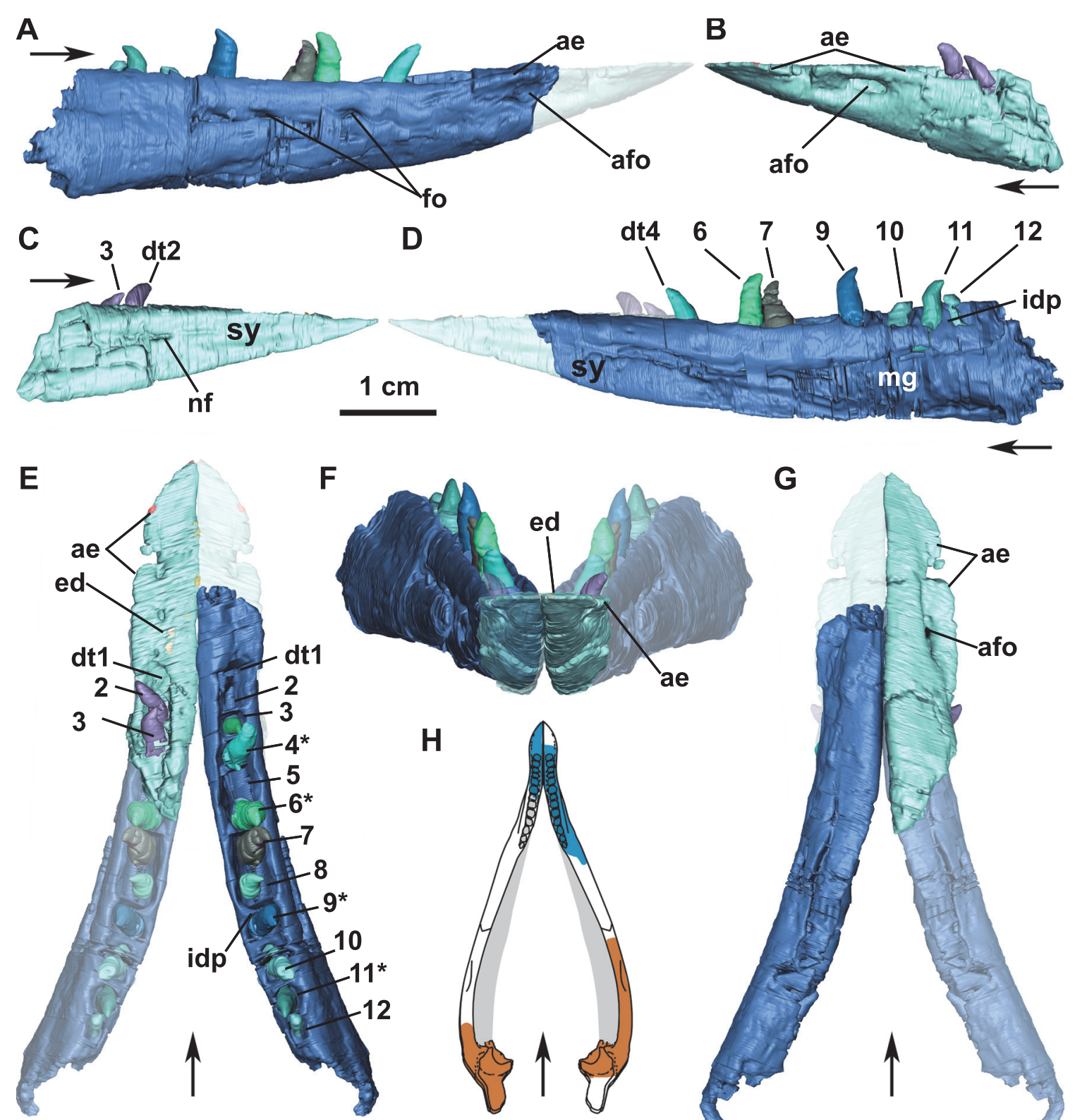

G
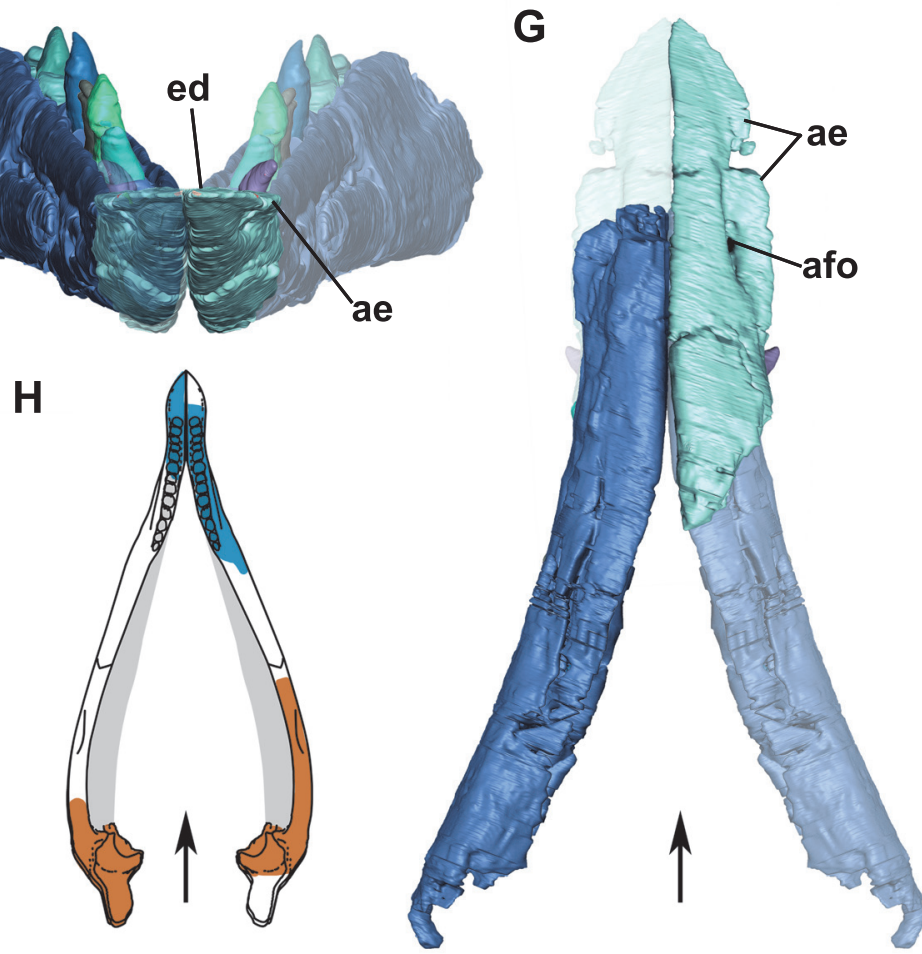

FIGURE 15. 3D Reconstruction based on $\mu C T$-scan images of the anterior portion of the dentary of Aetosauroides scagliai (MCN-PV 2347). A, right dentary in lateral view, with reconstructed tip. B, anterior tip of the left dentary in lateral view. C, anterior tip of the left dentary in medial view. D, right dentary in medial view. $\mathrm{E}$, combined anterior portions of the dentary of MCN-PV 2347 in dorsal view. F, combined anterior portions of the dentary in anterior view. G, combined anterior portions of the dentary of MCN-PV 2347 in ventral view. $\mathrm{H}$, mandible reconstruction with elements preserved in MCN-PV 2347. Asterisk $\left({ }^{*}\right)$ tooth number indicates that the teeth have resorption pits. Abbreviations: ae, anterior lateral expansion; afo, anterior foramen; dt, dentary teeth or alveolus; ed, edentulous portion; fo, foramen; idp, interdental plates; nf, nutrient foramen; sy, symphysis; mg, Meckelian groove.

31185-84), this foramen is confluent with a marked groove that reaches the anterior portion of the dentary. As suggested by Schoch and Desojo (2016), this foramen may have allocated the mandibular branch of the trigeminal cranial nerve. Small foramina are present in a single row close to the dorsal margin of the dentary (Figures 5A and 15A: fo) as in other aetosaurs, although they are not as large or as abundant as those of Stagonolepis olenkae (ZPAL AbllI 573; Sulej, 2010), Desmatosuchus smalli (TTUP 9024; Small, 2002), Paratypothorax andressorum (SMNS 19003; Schoch and Desojo, 2016), and Typothorax coccinarum (Reyes et al., 2021). Small (2002) described a large posterior 
foramen for $D$. smalli, but no comparable structure is present in MCN-PV 2347, PVL 2059, or UFSM 11505 , or in the other aetosaurs Stagonolepis robertsoni (Walker, 1961) and Coahomasuchus kahleorum (NMMNH P-18496). That large posterior foramen is confluent with a posterior groove in D. smalli (TTUP 9024), a condition shared with Stagonolepis olenkae (ZPAL AbIII 573), Longosuchus meadei (TMM 31185-84 and TMM 31185-84), and cf. Lucasuchus hunti (TMM 31100-1338). Aetosaurus ferratus (SMNS 5770 S-16), and Stenomyti huangae (DMNH 61392) also have a large foramen at this position, but lack the associated posterior groove.

Twelve alveoli are observed in the right dentary of MCN-PV 2347, a number higher than in other aetosaurs (see Discussion). Only the first three alveoli are preserved on the left dentary (Figure 15E). The alveoli are separated by wellspaced, unfused triangular interdental plates, which are smaller than those in the maxilla (Figure 15D). In medial view, the symphysis represents less than one third of the total length of the dentary. The splenial is missing, medially exposing the Meckelian groove, which is delimited dorsally by a short wall of the dentary. The Meckelian groove enters the symphysis, ending in a nutrient foramen. The presence of this foramen is shared with other aetosaurs, although is small by comparison. The symphysis is not as rugose as that of other aetosaurs but resembles the condition in a juvenile Typothorax coccinarum specimen (TTUP 9214; sensu Martz, 2002).

Articular: Both articulars are preserved in MCN-PV 2347 (Figure 16), although the right one is broken posteriorly (Figure 7A-D). The articular resembles that of other aetosaurs, being short anteroposteriorly with a broad articular glenoid for the articulation with the quadrate (Figure 16A, C and I: as). The articular glenoid is situated at the level of the dorsal margin of the dentary in UFSM 11505 and in the reconstructed MCN-PV 2347, differing from other aetosaurs in which it is more ventrally positioned (Parrish, 1994; Desojo and Vizcaino, 2009). The articular glenoid has a large surface on the lateral portion (for the reception of the lateral condyle, which is slightly shared with the surangular) and a smaller medial area (for the reception of the medial condyle). The medial surface of the glenoid projects medially, as in other aetosaurs, and bears a small dorsal foramen on its posterior margin (Figure 16A-D, H-l: fo). The articular foramen is shared with Acaenasuchus geoffreyi (Marsh et al., 2020), Revueltosaurus callenderi, phytosaurs, and loricat- ans (Nesbitt, 2011), but Marsh et al. (2020) considered it absent in the aetosaurs Longosuchus meadei (although it may be present in specimen TMM 31185-98) and Desmatosuchus smalli.

The articular contacts the surangular laterally, with the anterior portion of the glenoid having a socket for the surangular medial shelf (Figure $16 \mathrm{H}$ : sus). The contact with the surangular runs until the end of the retroarticular process. The ventral margin of the articular bears a ridge that separates the prearticular from the surangular, as reported by Walker (1961) for Stagonolepis robertsoni. The prearticular fits ventromedially into the articular, obscuring the ventromedial exit of the articular foramen (Figure 16E and F: fo2).

In lateral view, the surangular and the articular form a dorsoventrally slender retroarticular process (Figure 16G-I: rap). In MCN-PV 2347 and MCP$3450-P V$, there is no dorsomedially projected process like those commonly observed in most other aetosaurs. Only a concave medial area is present between the articular glenoid and the retroarticular process in dorsal view (Figure 16A). This projection also seems to be absent in Desmatosuchus spurensis (MNA V9300; Parker, 2008) and Desmatosuchus smalli (TTUP 9024). The shape of this projection is variable among aetosaurs, being thorn-like in most aetosaurine aetosaurs (e.g., Aetosaurus ferratus, SMNS 5770 S-21; Stenomyti huangae, Small and Martz, 2013; Paratypothorax andressorum, Schoch and Desojo, 2016) and in Stagonolepis olenkae (Sulej, 2010), but more squared-off in Longosuchus meadei (TMM 3118584B) and Stagonolepis robertsoni (NSM cast; Walker, 1961).

Angular: The right angular of MCN-PV 2347 is fairly complete, missing its anterior portion (Figure $17 A-E)$. It is generally similar to the morphology of other aetosaurs, being unornamented, with an anterior end with a rather triangular cross-section (Figure 17B), as in Stagonolepis olenkae (Sulej, 2010). It becomes deeper and more slender posteriorly, assuming a ' $J$ ' shape in cross-section (Figure $17 \mathrm{C}$ and $\mathrm{E})$. It forms the ventral margin of the posterior portion of the mandibular fenestra, articulating with the surangular posterodorsally. The articulations with the splenial and with the dentary are not preserved.

Prearticular: The prearticular of MCN-PV 2347 is a laminar bone that forms the posteroventral border of the mandible, contacting the articular dorsally, the angular ventrolaterally, and (probably) the splenial anteriorly (Figure 17G: asp), as in other aetosaurs (e.g., Desmatosuchus spurensis, MNA 9300; 


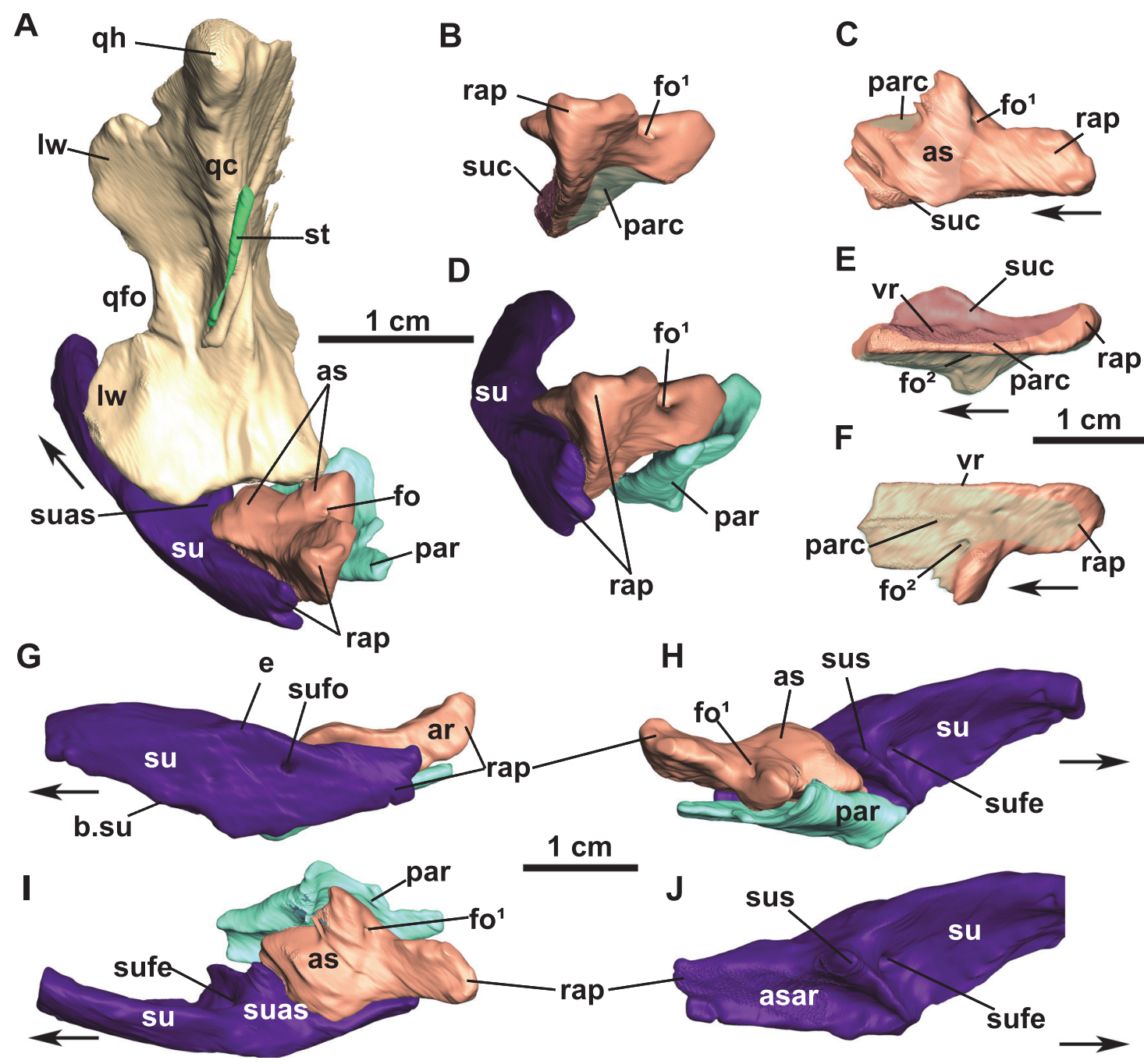

FIGURE 16. 3D Reconstruction based on $\mu$ CT-scan images of the posterior portion of the mandible of Aetosauroides scagliai (MCN-PV 2347). A, articulation between the left quadrate and left mandible in postero-lateral view (including the position of the stapes). B, left articular in posterior view. C, left articular in dorsal view. D, left mandible in posterior view. E, left articular in lateroventral view. F, left articular in ventral view; G, left mandible in lateral view. $\mathrm{H}$, left mandible in medial view. I, left mandible in dorsal view. J, left surangular in medial view. Abbreviations: ar, articular; as, glenoid; asar, articulation facet for the articular; b.su, broken surface of the surangular; e, elevation; fo, foramen; Iw, lateral wing of the quadrate; par, prearticular; parc, prearticular contact of the articular; qc, quadrate crest; qfo, quadrate foramen; qh, quadrate head; rap, retroarticular process; st, stapes; su, surangular; suas, surangular articulation with quadrate; suc, surangular contact of the articular; sufe, surangular foramen medial exit; sufo, surangular foramen; sus, medial shelf of the surangular; vr, ventral ridge.

Longosuchus meadei, TMM 31185-84; Neoaetosauroides engaeus, Desojo and Báez, 2007). Only the posterior portion is preserved in the left prearticular (Figure 16A, D, G-I: par), and only the right element is almost complete (Figure 17F-H). The right prearticular is displaced by the angular and is visible in lateral view in the right porterior portion of the skull (Figure 7A-B: par). It has expanded anterior and posterior ends, and is slightly twisted at the mid-portion (Figure 17F-H). Anteriorly, it exhibits a thick, overhanging medial shelf that probably contacted the splenial, which would have covered a concave medial area at the expanded anterior portion. This concave area represents the posterior end of the medial inner margin of the Meckelian fossa (Figure 17G: mk), as observed by Walker (1961) for Stagonolepis robertsoni. The infra-Meckelian foramen indicated by Walker (1961) could not be confirmed due to the lack of a splenial in MCN-PV 2347.

The thin posterior portion of the prearticular follows the ventromedial contour of the articular 


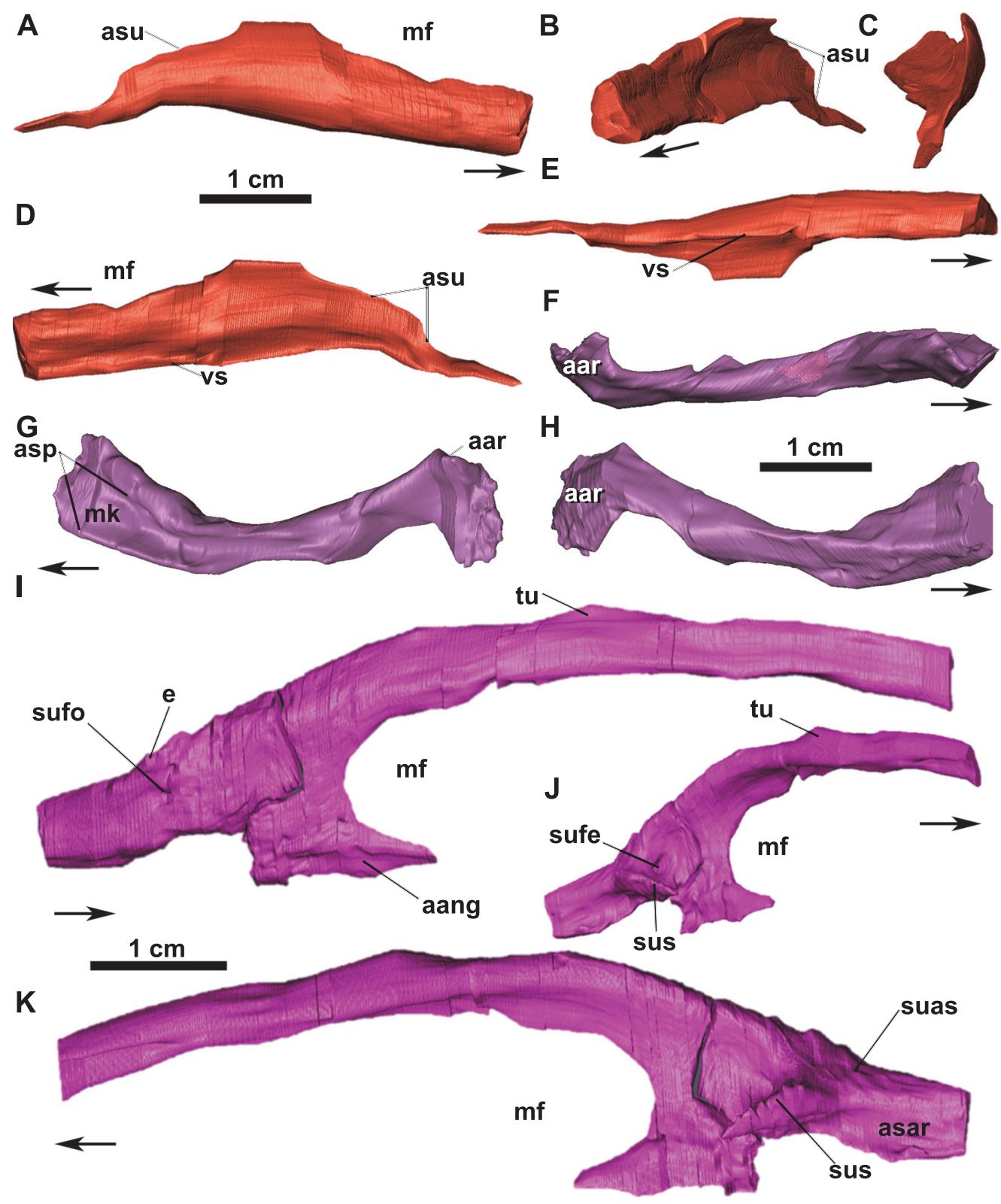

FIGURE 17. 3D Reconstruction based on $\mu C T$-scan images of the right angular ( $A-E)$, prearticular $(F-H)$, and surangular (I-K) of Aetosauroides scagliai (MCN-PV 2347) in lateral (A, H, and I), antero-medial (B and J), medial (D, G, and $\mathrm{K})$, dorsal $(\mathrm{F})$, posterior $(\mathrm{C})$, and ventral $(\mathrm{E})$ views. Abbreviations: aang, articulation surface with the angular; asar, articulation surface of the articular; asp, articulation with the splenial; asu, articulation with the surangular; e, elevation; $\mathrm{mf}$, mandibular fenestra; mk, internal meckelian groove; rap, retroarticular process; sufe, surangular foramen medial exit; sufo, surangular foramen; sup, surangular process; sus, medial shelf of the surangular; tu, surangular process; vs, ventral shelf of the angular.

(Figure 17D: asu). The medial edge lies between the ventral ridge of the articular and the glenoid medial projection, along with the retroarticular process as in Neoaetosauroides engaeus (according to Desojo and Báez, 2007) and Stagonolepis robertsoni (according to Walker, 1961). It has an overhanging flange which follows the medial projection of the articular. The left element terminates in a very thin, acute tip, which forms the medial margin of the retroarticular process complex (Figure 16H). Only a fragment of the posterior end of the prearticular is preserved in MCP-3450-PV.

Surangular: In MCN-PV 2347 the right surangular is fairly complete (Figure 17I-K), being broken only at its posterior end. In contrast, the left element of MCN-PV 2347 (Figure 16) and of MCP-3450-PV 
(Figure 9) is represented only by the retroarticular process. Both specimens resemble the condition of other Aetosauroides scagliai specimens (PVL 2052 and UFSM 11505) and some other aetosaurs, like Stenomyti huangae (Small and Martz, 2013), Stagonolepis robertsoni (Walker, 1961), and Stagonolepis olenkae (Sulej, 2010). The surangular is comparatively shorter anteroposteriorly and deeper dorsoventrally in Longosuchus meadei (TMM 31185-84) than in A. scagliai. Further differences are present in the shape of the retroarticular process, for which see below.

The surangular is an anteroposteriorly elongate bone, with a long, concave anterior process, which projects dorsally to form the dorsal border of the mandibular fenestra. At the dorsal surface of this process is a shallow 'mound-like' ascending flange (Figure 17I-K: tu), called the surangular process by Walker (1961), which is also present in other material of Aetosauroides scagliai (Brust et al., 2018) and aetosaurs such as Stagonolepis olenkae (Sulej, 2010). The surangular process is much more weakly developed in MCN-PV 2347 than in UFSM 11505 (Brust et al., 2018) and PVL 2052. This mound is also better developed in Stenomyti huangae (DMNH 61392), which is a putatively juvenile specimen (sensu Hoffman et al., 2019), than in MCN-PV 2347. This difference between $A$. scagliai individuals is here interpreted as intraspecific variation.

As in other aetosaurs, the posteroventral border of the mandibular fenestra is formed by a small anterior contribution of the surangular, which is replaced ventrally by the angular (Figure 17l: a.ang). The contact of the surangular with the angular seems to continue medially in MCN-PV 2347 and UFSM 11505, with a short medial expansion of the surangular (Figure $17 \mathrm{~J}-\mathrm{K}$ : sus). The posterior portion of the surangular also bears an elliptical posterior surangular foramen (Figures 16G and 18A: sufo), which is followed anteriorly in MCP-3450-PV by two small foramina (Figure 9: fo). The surangular foramen exits ventromedially in the anterior area of the surangular medial shelf (Figures $16 \mathrm{H}-\mathrm{J}$ and $17 \mathrm{~J}-\mathrm{K}$ : sufe), as occurs in Longosuchus meadei (TMM 31185-84). This medial shelf is anteroventrally oriented, as in other aetosaurs (e.g., Stagonolepis olenkae, ZPAL AbIII 578/34; L. meadei, TMM 31185-84), contacting the anterolateral rim of the articular and the anterior margin of the prearticular posteriorly.

In lateral view, a faint ridge is present dorsal to the surangular foramen in MCN-PV 2347 (Figure 17I: e) and in MCP-3450-PV (Figure 9E: e), extending from the glenoid area toward the dorsal rim of the mandibular fenestra. This ridge forms an elevated convex region dorsal to the surangular foramen, delimiting a depressed area near the concave dorsal rim of the retroarticular process. Similarly, a more marked ridge is preserved in UFSM 11505, Stagonolepis olenkae (Sulej, 2010) and probably in Paratypothorax andressorum (SMNS 19003). A faint elevation delimits a flat area between the maxillary fenestra and the surangular foramen in MCP-3450-PV (Figure 9A and B). This region is somewhat different in UFSM 11505, which has an elevated area near the mandibular fenestra but no marked ridge. As in other aetosaurs, the lateral surface is devoid of ornamentation in the studied specimens, contrasting with the condition of Acaenasuchus geoffreyi (Marsh et al., 2020). Additionally, there is no lateral shelf of the surangular, contrasting with the condition in erpetosuchids (Ezcurra et al., 2017; Lacerda et al., 2018), ornithosuchids (von Baczko and Desojo, 2016), gracilisuchids, and phytosaurs (e.g., Ezcurra, 2016).

The morphology of the retroarticular process was previously unknown in Aetosauroides scagliai (broken in UFSM 11505), but this structure is preserved in MCN-PV 2347 (Figure 16G) and MCP3450-PV (Figure 9A-B). It is anteroposteriorly elongated and dorsoventrally short and with a dorsally projected acuminate end. The slender condition of the retroarticular process is shared with members of Aetosaurinae (sensu Parker, 2016a), such as Stenomyti huangae (Small and Martz, 2013), cf. Aetosaurus ferratus (MCZ 9479R), and to a minor degree with Paratypothorax andressorum (SMNS 19003; Schoch and Desojo, 2016). This contrasts with the proportionally shorter and deeper retroarticular process seen in desmatosuchine aetosaurs such as Stagonolepis robertsoni (NSM cast), Stagonolepis olenkae (Sulej, 2010), Desmatosuchus spurensis (MNA V9300; Parker, 2008), Desmatosuchus smalli (TTUP9024; Small, 2002), and Longosuchus meadei (TMM 31185-84B; Parrish, 1994). Also, the retroarticular process of most of these taxa ends in a concave non-acuminate process, unlike the condition of $A$. scagliai.

Dentition. Several well-preserved premaxillary and dentary teeth are in situ or close to their respective alveoli in MCN-PV 2347 (Figures 5B, $5 \mathrm{E}, 15 \mathrm{~A}-\mathrm{E}, 18 \mathrm{~A}$ and 18B; Table 6). Although broken, the rostralmost left maxillary tooth is also preserved (Figures $6 \mathrm{~A}-\mathrm{C}$ and $18 \mathrm{~F}$ ), and one probable isolated maxillary tooth is preserved ventral to the left ramus of the mandible (Figure 5B and F: i.mxt). 

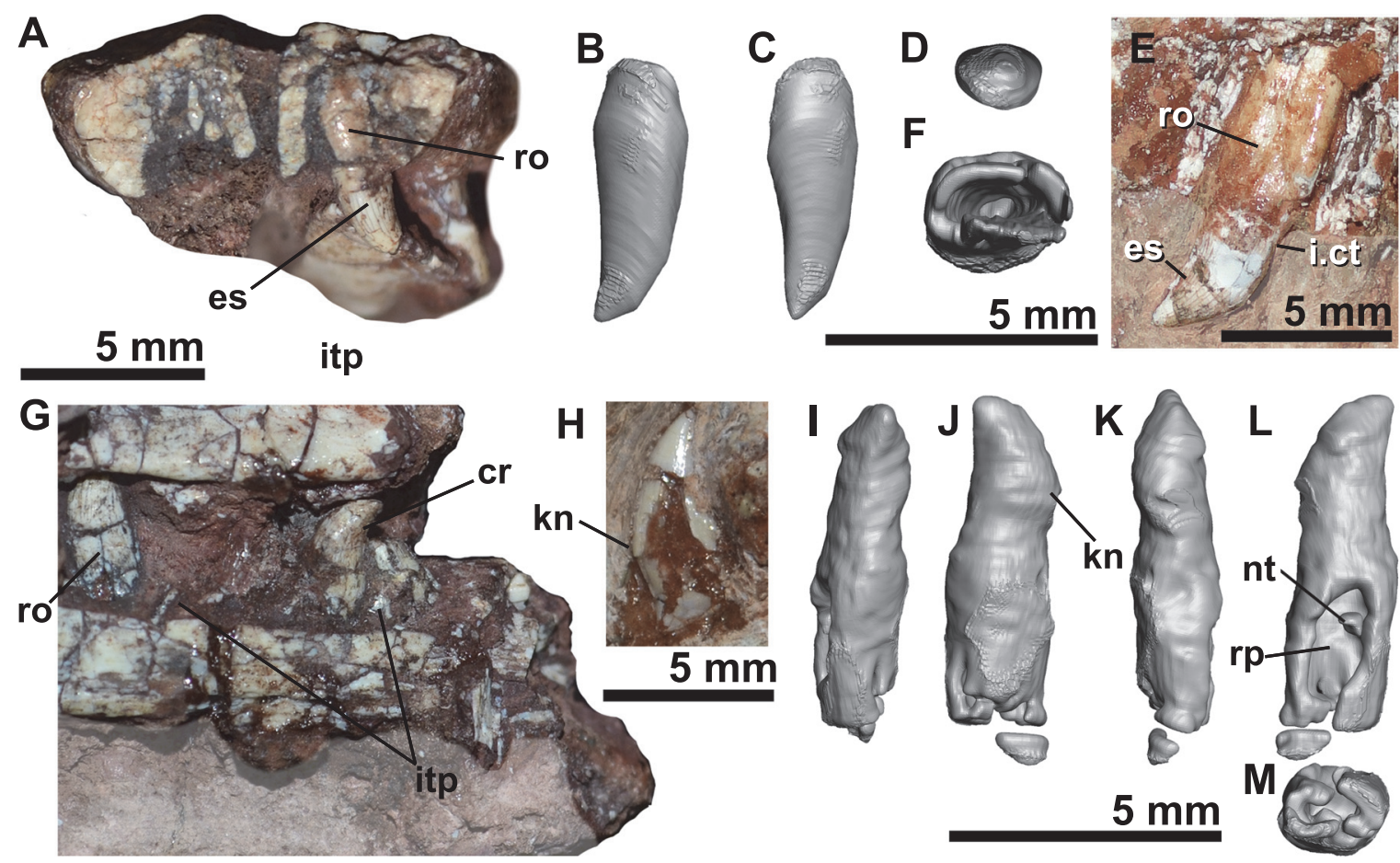

FIGURE 18. Dental morphology of Aetosauroides scagliai (MCN-PV 2347, MCP-3450-PV and UFSM 11505). A, Transversal section of the premaxilla of MCN-PV 2347 showing the premaxillary tooth in mesial view. B-C, 3D reconstruction based on $\mu$ CT-scan images of the premaxillary tooth in labial (B), distal (C), and basal (D) views. E, in situ maxillary tooth of UFSM 11505 in labial view. F, 3D reconstruction based on $\mu$ CT-scan images of the maxillary tooth in basal view. G, medial view of maxilla and dentary of MCN-PV 2347. H, isolated dentary teeth of MCP-3450-PV. I-M, $3 \mathrm{D}$ reconstruction based on $\mu C T$-scan images of the dentary tooth of MCN-PV 2347 in basal $(\mathrm{I})$, distal $(\mathrm{J})$, labial $(\mathrm{K})$, distal (L), and lingual (M) views. Abbreviations: cr, crown; es, enamel striation; i.ct, incipient constriction; itp, interdental plate; kn, knee; nt, new tooth; ro, root; rp, resorption pit.

An isolated dentary tooth was found below the parietal of MCP-3450-PV (Figure 18H). In both specimens, the teeth are recurved and labiolingually narrower than mediodistally long, thus not having the bulbous, leaf-shaped morphology of many aetosaurs. This morphology is consistent with other Aetosauroides scagliai specimens (Casamiquela, 1967; Brust et al., 2018), but contrasts with the dental morphology of all other aetosaurs (including Stagonolepis robertsoni), with the exception of Coahomasuchus kahleorum (TMM 31100437; sensu Parker, 2016a) and Coahomasuchus chathamensis (Heckert et al., 2017). Most of the teeth of MCN-PV 2347 fit in the ziphodont definition of Hendrickx et al. (2015), in which 'the labiolingual width of the tooth is less than $60 \%$ of the mesiodis-

TABLE 6. Measurements of the teeth of Aetosauroides scagliai (MCN-PV 2347 and UFSM 11505).

\begin{tabular}{ccccccc}
\hline Specimen & Position & $\begin{array}{c}\text { Crown height Crown length } \\
\text { (CH) }\end{array}$ & $\begin{array}{c}\text { CH/CL } \\
\text { (CL) }\end{array}$ & $\begin{array}{c}\text { Crown } \\
\text { width }\end{array}$ & $\begin{array}{c}\text { Crown base } \\
\text { length }\end{array}$ \\
\hline UFSM 11505 & MX3L & 4.9 & 3.1 & $63.3 \%$ & - & 2.7 \\
UFSM 11505 & MX6L & 4.4 & 2.9 & $65.9 \%$ & - & 3.3 \\
UFSM 11505 & MX8L & 4.6 & 3.2 & $69.6 \%$ & - & 3.0 \\
UFSM 11505 & PMX4R & 2.3 & 1.6 & $69.6 \%$ & - & 1.7 \\
UFSM 11505 & D?L & 4.9 & 2.1 & $42.9 \%$ & - & 2.4 \\
MCN-PV 2347 & PMX1L & 2.8 & 1.5 & $53.6 \%$ & 1.4 & 1.6 \\
MCN-PV 2347 & PMX3L & 3.5 & 2.1 & $60.0 \%$ & 1.1 & 2.1 \\
MCN-PV 2347 & D10R & 3.9 & 2.3 & $59.0 \%$ & - & - \\
\hline
\end{tabular}


tal length'. However, the measured teeth of UFSM 11505 fall slightly outside this range, thus we prefer the terminology 'recurved' to describe them. The presence and number of serrations on both mesial and distal carina varies depending on the position of the tooth, see below.

Brust et al. (2018) indicated that there were no constrictions at the base of the crown in the teeth of UFSM 11505. Notwithstanding, most of the described teeth of UFSM 11505 were erupted and in situ, thus precluding a precise description of their bases. However, an exposed, in situ tooth of UFSM 11505 (Figure 18E; prior to the preparation of the specimen) and an isolated tooth (Brust et al., 2018: figure 6C) show a constriction at the root level (at the cervix sensu Hendrickx et al., 2015). This morphology slightly contrasts with the condition in other aetosaurs, in which the constriction is located at the crown (with enamel still visible, thus above the cervix). The constriction in UFSM 11505 instead seems to be a function of expansion at the root. First-hand observation and analysis of the $\mu C T$-images of MCN-PV 2347 teeth show that no marked constriction is present at the base of the crowns (Figure 18).

Enamel striations are observed in MCN-PV 2347 (Figure 18A and G: es), and are also preserved in UFSM 11505 (Brust et al., 2018; Figure 18E: es) and in other aetosaurs (e.g., Desmatosuchus smalli, Small, 2002; Paratypothorax andressorum, Schoch and Desojo, 2016; Stenomyti huangae, DMNH 60708). No other dental structures, like labial wear facets or other ornamentation on the enamel surface, were observed in the preserved teeth of MCN-PV 2347 and UFSM 11505. As noted previously, the dental formula of MCN-PV 2347 is: premaxilla 4, maxilla 10/12(?), and dentary 12(?). This is similar to UFSM 11505 (premaxilla 4 and maxilla 10?) and PVL 2059 (premaxilla $\sim 4$, maxilla $\sim 10$ ? and dentary 11?).

Premaxillary teeth: As described for UFSM 11505 (Brust et al., 2018), the premaxillary teeth of MCNPV 2347 are more cylindrical and less recurved than the other teeth (Figure 18A, B). They have less convex mesial margins and more straight distal margins, a pattern consistent with that of UFSM 11505 and some disarticulated teeth of Coahomasuchus chathamensis (according to Heckert et al., 2017). There are no serrations visible on the premaxillary teeth in MCN-PV 2347, a condition shared with UFSM 11505 (Brust et al., 2018).
The crown height of the premaxillary teeth is nearly twice the length at base (see Table 6), being relatively slender compared to other aetosaurs. The teeth increase in size posteriorly, as in other aetosaurs (e.g., Neoaetosauroides engaeus, Desojo and Báez, 2007; Paratypothorax andressorum, Schoch and Desojo, 2016; Stagonolepis robertsoni, ELGNM 38, Walker, 1961). Althought not bulbous, as in $P$. andressorum (SMNS 19003), the premaxillary teeth of MCN-PV 2347 and UFSM 11505 are more rounded than the other teeth, resembling the premaxillary teeth of other aetosaurs more than they do the maxillary or dentary dentition. The tip is distally curved in A. scagliai premaxillary teeth.

Maxillary teeth: These are the larger teeth from the skull and mandible, with an oval cross-section (Figure 18F) and a convex mesial margin and concave distal margin, as in UFSM 11505 (Brust et al., 2018). No serrations or denticles are observed on the available teeth of MCN-PV 2347 (Figure 18), but their apices are damaged, and their absence can possibly be attributed to wear or to intraspecific variation. The serrations in UFSM 11505 are restricted to the apical portions of the medial and distal margins of the teeth.

Dentary teeth: The dentary teeth are poorly preserved in UFSM 11505 and PVL 2059, but present and well preserved in MCN-PV 2347. Six teeth are preserved in situ on the left and three in the right dentary. The apex is strongly posteriorly recurved and acute. The isolated tooth of MCP-3450-PV exhibits this same morphological pattern, suggesting it is a dentary tooth. No serrations are visible on the dentary teeth of MCN-PV 2347 and MCP-3450PV.

The dental 'knee' of Brust et al. (2018) is also present in MCN-PV 2347 and in MCP-3450-PV dentary teeth, but the lanceolate cross-section is not observed in MCN-PV 2347, which is more elliptical than lanceolate. The 'knee' is also present in the maxillary dentition of UFSM 11505, but it seems to be more marked in dentary teeth of all specimens, including PVL 2059 and MCP-3450-PV (Figure 18L). The fourth, sixth, ninth, and eleventh teeth of the left dentary of MCN-PV 2347 present resorption pits for the replacement of younger teeth on the lingual surfaces (Figure 18L: rp) and have already formed the tips of their apices (Figure 18: nt). The third and the eighth teeth seem to be unerupted replacement teeth with only one to two thirds of their apices formed. 


\section{DISCUSSION}

\section{Taxonomic Affinity of the Studied Specimens}

The overall morphology of the specimen MCN-PV 2347 is consistent with Aetosauroides scagliai (sensu Brust et al., 2018) as indicated by the following combination of characters: (1) maxilla excluded from the margin of the external naris (shared with PVL 2052, PVL 2059, and UFSM 11505); (2) ventral margin of the dentary convex and without a sharp inflection (shared with PVL 2052, PVL 2059, and UFSM 11505); (3) recurved ziphodont-like teeth (shared with PVL 2059 and UFSM 11505); and (4) oval to elliptical fossae ventral to the neurocentral suture of the cervical vertebrae (shared with PVL 2073, PVL 2052, PVL 2059, UFSM 11505, and ULBRAPV003T). The specimen MCP-3450-PV has oval to elliptical fossae ventral to the neurocentral suture of the cervical and trunk vertebrae (shared with PVL 2073, PVL 2052, PVL 2059 , and UFSM 11505) and thus is also referable to $A$. scagliai (see Paes Neto et al., 2021b). Based on the present study, we consider the presence of more than 10 dentary teeth to be a possible autapomorphy of $A$. scagliai.

\section{Skull Reconstruction of Aetosauroides scagliai}

The present study has reviewed the cranial osteology of Aetosauroides scagliai, focusing on the newly recognized specimen MCN-PV 2347. Previously, the skull of Aetosauroides scagliai was known only by two incomplete specimens recovered from Argentina (Casamiquela, 1960, 1961, 1967; Heckert and Lucas, 2002; Desojo, 2005; Desojo and Ezcurra, 2011; Parker, 2014): (1) PVL 2059, which is similar in size to the Brazilian ones but lacks the anterior tip and posterior portion of both the skull and mandible; and (2) PVL 2052, which preserves natural casts of the lateral surface of the skull and mandible. Another, much larger Argentine specimen bearing cranial remains (PVSJ 326 ) has been assigned to $A$. scagliai (Desojo, 2005; Desojo and Ezcurra, 2011; Ezcurra, 2016; Parker, 2016a), but details of its osteology remain unpublished. Recently, the Brazilian specimen UFSM 11505 was reported by Brust et al. (2018), who described the morphology of the premaxilla and general details of the teeth and mandible for the first time. Here, we present additional, previously unknown details of the posterior portion of this skull and mandible following additional preparation. Based on this information, a new integrated reconstruction of the skull and mandible of Aetosauroides scagliai is shown in Figure 19.
Remarkable among the new information revealed for Aetosauroides scagliai is the presence of a 'triradiate' posterodorsal process on the posterior process of the maxilla, reported here in $\mathrm{MCN}$ PV 2347 and UFSM 11505. As indicated by Butler et al. (2014), a posterodorsal process is present in other aetosaurs, and is also shared with gracilisuchids, in which it is much more pronounced (e.g., Gracilisuchus stipanicicorum MCZ 4116; Butler et al., 2014). In aetosaurs the posterodorsal process seems to be associated with finger-like posterior projections, of which the middle one is the longest in A. scagliai. In the triradiate posterior process of Aetosaurus ferratus (SMNS 5770 S-16; Schoch, 2007), all projections are of similar size; whereas in Paratypothorax andressorum (SMNS 19003; Schoch and Desojo, 2016) the ventral one is the largest. In other aetosaurs only two projections are present in the maxilla, with the ventral one being the largest, as is the case in Stenomyti huangae (DMNH 60708) and Desmatosuchus smalli (TTUP 9024). This may also be true for Desmatosuchus spurensis (UMMP V7476), Longosuchus meadei (TMM 31185-84), and Kocurypelta silvestris (Czepiński et al., 2021), although it is difficult to determine given available material.

The absence of a pneumatic cavity in the medial portion of the maxilla in Aetosauroides scagliai (MNC 2347) indicates that this feature is restricted to stagonolepidids, and thus is not a general synapomorphy of aetosaurs as suggested by Small (2002). The largest described specimen of A. scagliai (PVL 2052) does not preserve the maxillae in medial view, precluding consideration of this condition. However, in other taxa the presence of the pneumatic cavity does not appear to be ontogenetically variable, as it is already present in DMNH 34565, a putatively juvenile specimen of Stenomyti huangae (Small and Martz, 2013). This character also supports $A$. scagliai as distinct from S. robertsoni and cf. Calyptosuchus wellesi (Parker, 2018; UCMP 27414 and 27409), contra previous hypotheses of synonymy between these taxa (indicated by Heckert and Lucas, 2000; Heckert and Lucas, 2002; Lucas and Heckert, 2001).

The pneumatic cavity is known in several aetosaurs, including Stagonolepis robertsoni (according to Walker, 1961; Small, 2002), Stagonolepis olenkae (Sulej, 2010), Calyptosuchus wellesi (Parker, 2018), Desmatosuchus spurensis (UMMP V7476), Desmatosuchus smalli (TTUP 9024; Small, 2002), and Kocurypelta silvestris (Czepiński et al., 2021). However, in Longosuchus meadei (TMM 31185-84), the pneumatic cavity is not 


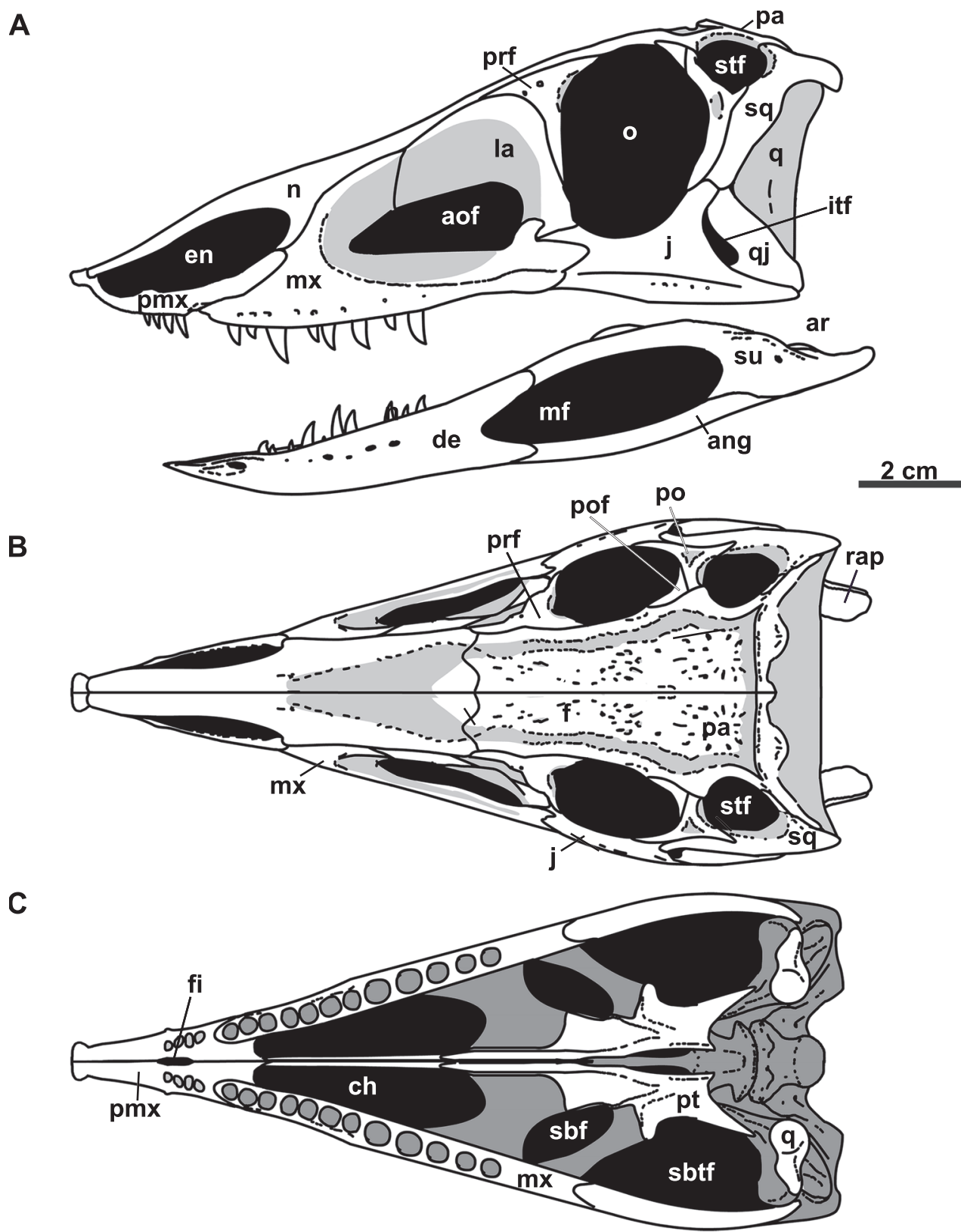

FIGURE 19. Skull reconstruction of Aetosauroides scagliai, based mainly on MCN-PV 2347 (scaled to this specimen), UFSM 11505 and PVL-2059. A, skull and mandible in lateral view. B, skull in dorsal view. C, skull in ventral view. Gray areas indicate depth. Abbreviations: ang, angular; aof, antorbital fenestra; ar, articular; ch, choana; de, dentary; itf, infratemporal fenestra; f, frontal; fi, foramen incisivum; itf, infratemporal fenestra; j, jugal; la, lacrimal; mf, mandibular fenestra; mx, maxilla; n, nasal; ne, external nares; o, orbit; pa, parietal; pmx, premaxilla; po, postorbital; pof, postfrontal; prf, prefrontal; pt, pterygoid; q, quadrate; qj, quadratojugal; rap, retroarticular process; sq, squamosal; sbf, suborbital fenestra; sbtf, subtemporal fenestra; stf, supratemporal fenestra; su, surangular.

observable in medial view, being oriented toward the anterior region of the antorbital fenestra. Furthermore, this cavity was recently found to be absent in Typothorax coccinarum (Reyes et al., 2021), indicating that this feature may not be as consistent within Aetosauria as previously thought. Additional study is needed to determine whether this feature is present in other aetosaur taxa (e.g., Paratypothorax andressorum and Aetosaurus ferratus) in which the medial surface of the maxilla is currently inaccessible. Such a cavity does seem to be absent in other pseudosuchians (e.g., Prestosuchus chiniquensis, Mastrantonio et al., 2019; Parringtonia gracilis, Nesbitt and Butler, 2013). 
Palpebral bones dorsal to the orbit are absent in Aetosauroides scagliai (MCN-PV 2347; PVL 2059; UFSM 11505), like in many other aetosaurs known from well-preserved skulls. However, several 'small-sized' and narrow-bodied aetosaurs (e.g., Neoaetosauroides engaeus, Aetosaurus ferratus, and Stenomyti huangae) preserve these elements, which vary in number and usually have a loose contact with the prefrontal (Desojo and Báez, 2007; Schoch, 2007; Nesbitt et al., 2013). Small and Martz (2013) have identified the first palpebral in $S$. huangae to be in tight articulation with the prefrontal and frontal, forming the orbital rim. However, based on the first-hand observations of the $S$. huangae specimen DMNH 60708, we consider that the 'first palpebral' instead represents the posterior region (and posterior process) of the prefrontal, as occurs in all other aetosaurs. The suture indicated by Small and Martz (2013) cannot be traced toward the ventral region and probably represents a fracture. Corroborating our interpretation, the foramen on the element identified by Small and Martz (2013) is also preserved in the prefrontal of MCNPV 2347 and in A. ferratus (SMNS 5770 S-18).

With this noted, palpebrals are probably more common in aetosaurs than a direct reading of the record indicates, and their absence in Aetosauroides scagliai and some other aetosaurs is likely taphonomic. Palpebrals are delicate elements, often loosely attached to the rest of the skull, and would have been easily lost during decomposition and transport. In Aetosaurus ferratus (SMNS 5770 S-16), a depressed area in the lateral exposed surface of the ventral ramus of the prefrontal is present that receives the first palpebral. The prefrontal in A. scagliai (MCN-PV 2347 and UFSM 11505) and Paratypothorax andressorum (according to Schoch and Desojo, 2016) also shows this depression, although palpebrals are not preserved. This depression is probably correlated with the presence of palpebrals in specimens where these elements are absent, like in some loricatans (see Nesbitt et al., 2013), but further specimens are needed to support this conclusion.

The number of teeth in the dentary seems to be higher in Aetosauroides scagliai than in other aetosaurs. The dentary of MCN-PV 2347 bears 12 definite alveoli, and a few additional alveoli could be present. This is higher than the count of 10 (Casamiquela, 1961) or 11 (Heckert and Lucas, 2002) previously proposed for PVL 2059 (the only other available dentary for $A$. scagliai, as the teeth and alveoli are obscured by other elements in UFSM 11505). The number of dentary teeth varies from nine to 10 in Stagonolepis robertsoni (Walker, 1961) and Typothorax coccinarum (Martz, 2002; Reyes et al., 2021), from seven to 10 in S. olenkae (Sulej, 2010; Antczak, 2016), and from seven to eight in Aetosaurus ferratus (Schoch, 2007). At least seven dentary teeth are present in Neoaetosauroides engaeus (Desojo and Báez, 2007), Desmatosuchus smalli (Small, 2002), and Longosuchus meadei (Sawin, 1947), although intraspecific variation is unknown in these taxa. The putative dentary of Calyptosuchus wellesi bears at least nine alveoli (Parker, 2018), but its full count is still unknown. We recommend the use of dentary tooth counts as a potential taxonomic character within Aetosauria. In other pseudosuchians, higher numbers of dentary teeth are present, but in ornithosuchids they range from nine to 10 (Walker, 1964; von Baczko and Desojo, 2016) and up to 13 teeth in erpetosuchids (Ezcurra et al., 2017), potentially being phylogenetically informative (see Desojo, 2005).

\section{The Morphology of the Jugal and Quadratojugal in Pseudosuchians}

According to previous authors (e.g., Schoch and Desojo, 2016; Parker, 2016a) the shape of the jugal and the quadratojugal varies within Aetosauria. Parker (2016a) considered it as a character in his phylogenetic matrix (character 16) with the following states: the anterior process of the quadratojugal forms the ventral margin of the infratemporal fenestra (16:0) vs. where this process underlies the jugal, thus being excluded from the infratemporal fenestra (16:1). Nesbitt (2011) also included a character for this relationship (character 71), coding the small aetosaur Aetosaurus ferratus as having a quadratojugal split by the posterior portion of the jugal, as interpreted by Schoch (2007) and Desojo and Schoch (2016).

We have shown here that the jugal in Aetosauroides scagliai (based in MCN-PV 2347 and MCP-3450-PV; Figure 20A), contributes to the entire posterior ventral margin of the skull (representing state 16:0 of Parker, 2016a). This condition is identical to that of Stenomyti huangae (Small and Martz, 2013; Figure 21G); therefore, it is not an autapomorphy of the latter taxon as has been proposed. Furthermore, this condition was found to be present in all aetosaurs with known jugals and quadratojugals (contra Schoch, 2007; Nesbitt, 2011; Schoch and Desojo, 2016; Parker, 2016a) (Figures 20 and 21D-I), and probably represents a new synapomorphy for the clade. 

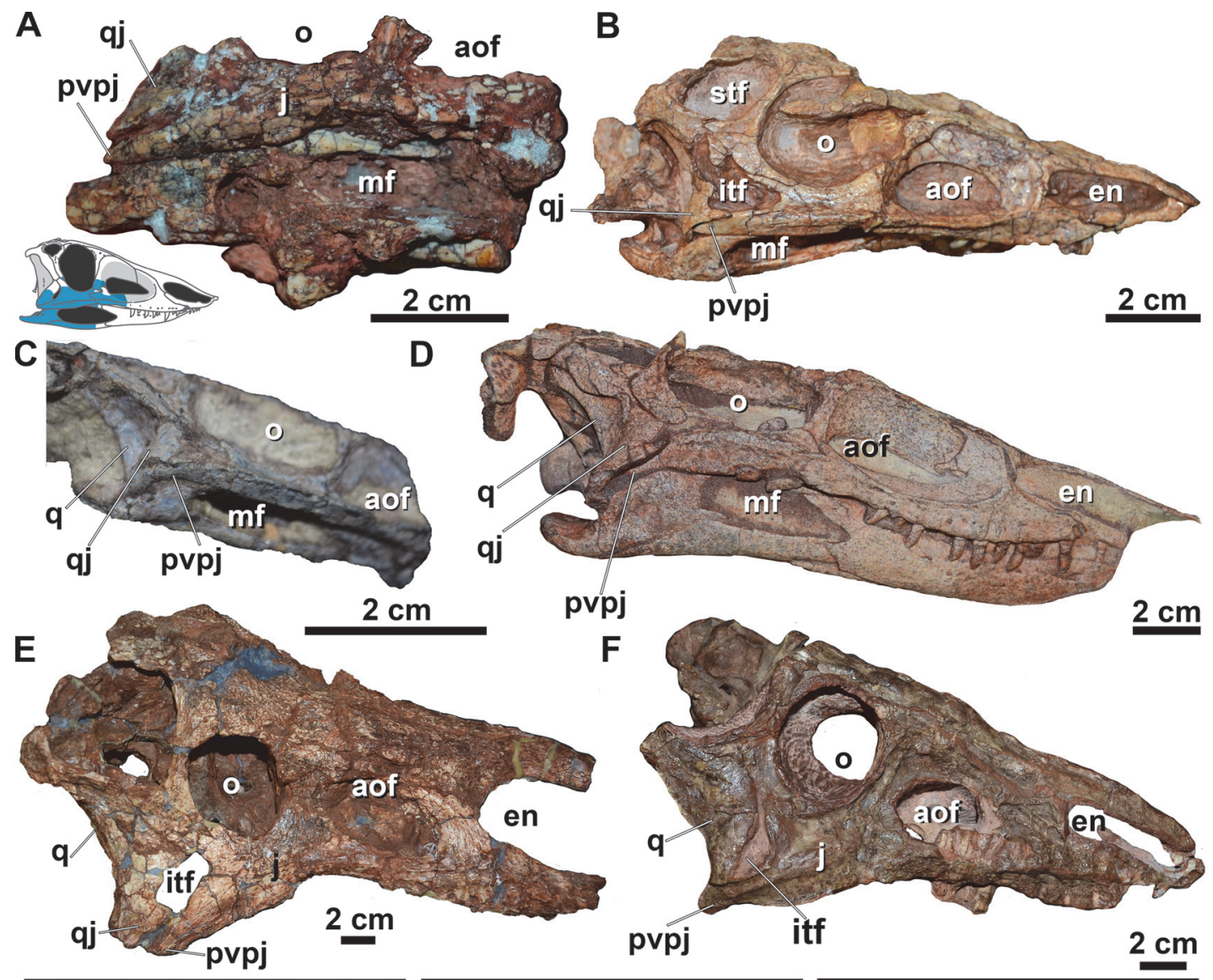

$2 \mathrm{~cm}$
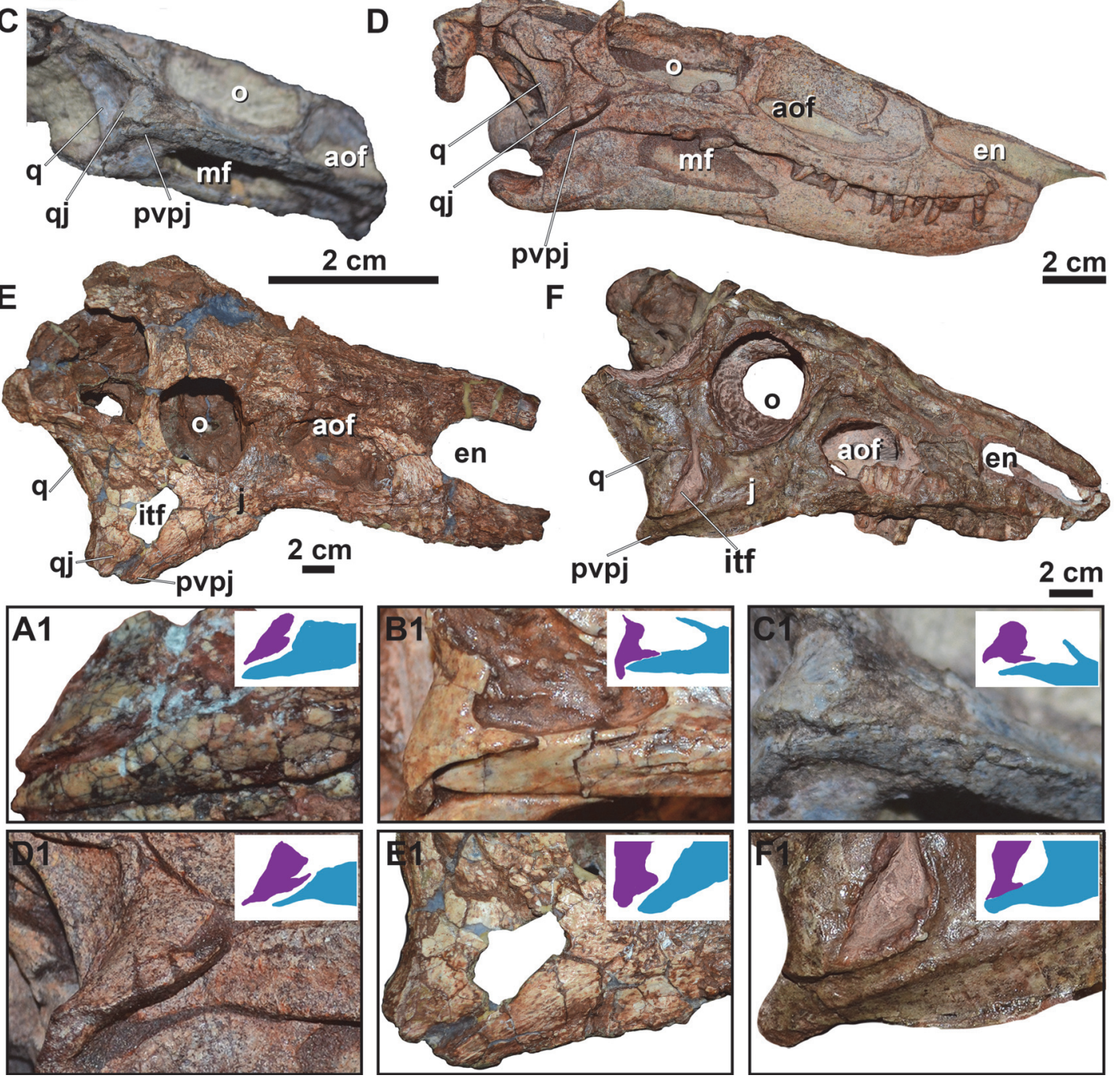

FIGURE 20. Jugal and quadratojugal of Aetosauria. Selected skulls of aetosaurs in lateral view and respectively close-ups: A and A1, Aetosauroides scagliai (MCN-PV 2347), with interpretative drawing. B and B1, Stenomyti huangae (DMNH 60708). C and C1, Aetosaurus ferratus (SMNS 5770 S-21). D and D1, Paratypothorax andressorum (SMNS 19003). E and E1, Desmatosuchus smalli (TTU P-9023). F and F1, Neoaetosauroides engaeus (PULR 4363). Abbreviations: aof, antorbital fenestra; itf, infratemporal fenestra; j, jugal; mf, mandibular fenestra; en, external nares; o, orbit; pvpj, posteroventral process of the jugal; q, quadrate; qj, quadratojugal; stf, supratemporal fenestra.

The morphology of the quadratojugal depicted by Schoch (2007) for Aetosaurus ferratus is based on interpretations of the specimens SMNS 5770 S7 and S-8, which are broken ventrally. However, the natural morphology of the quadratojugal is observable in SMNS 5770 S-16 (Schoch, 2007, fig. 4 ), in which the posterior portion of the jugal is anteroposteriorly elongated and runs ventral to the quadratojugal, just like in SMNS 5770 S-21 (Figure $20 \mathrm{C}$ ). This condition is clearly visible in some other 
A

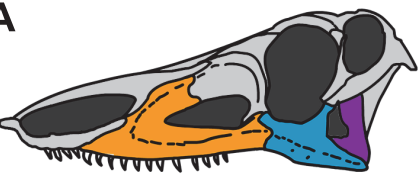

B

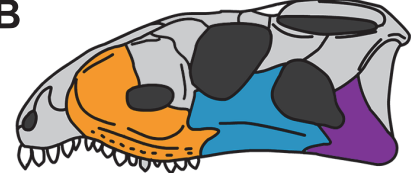

C

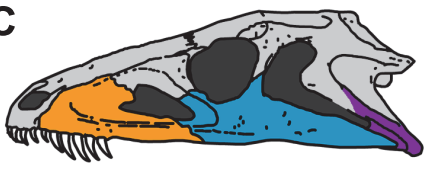

\section{Aetosauroides and aetosaur close relatives}
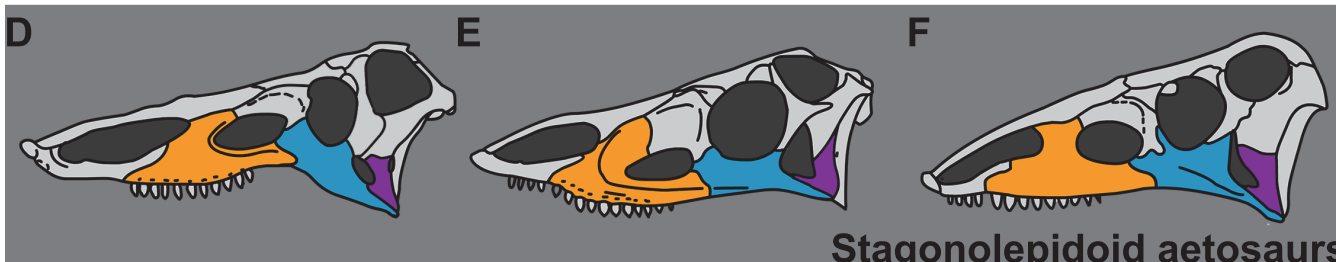

Stagonolepidoid aetosaurs
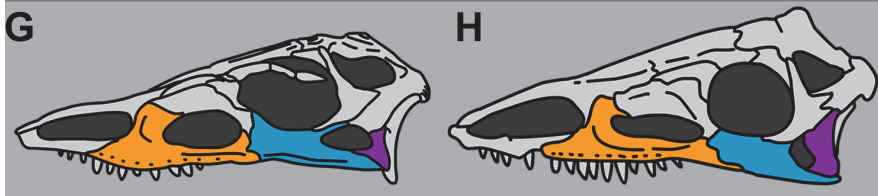

I

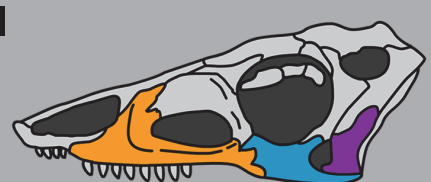

Aetosaurine aetosaurs
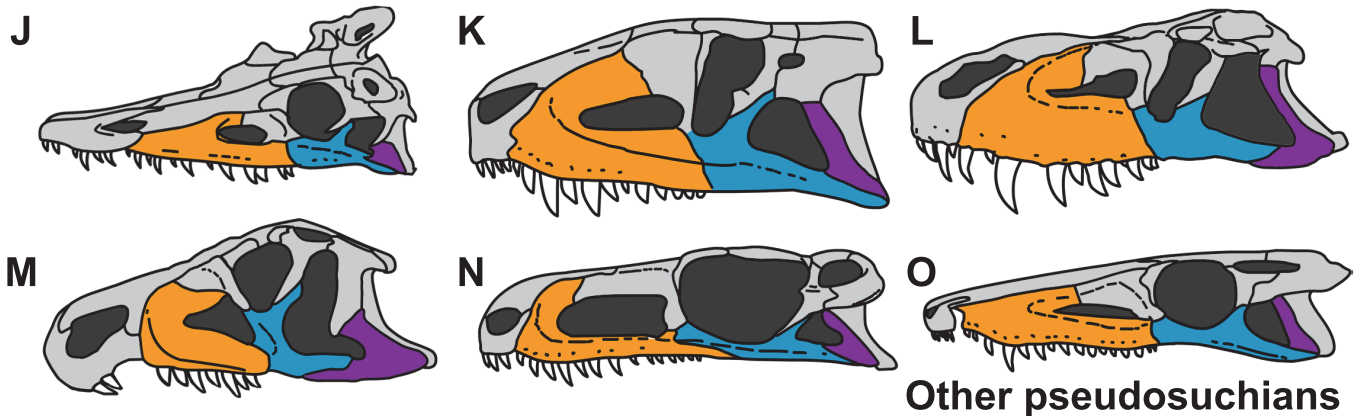

FIGURE 21. Comparisons of maxillae, jugals, and quadratojugals of Aetosauria and non-aetosaur pseudosuchians. A, the non-stagonolepidide aetosaur Aetosauroides. B, Revueltosaurus (redrawn from Nesbitt, 2011). C, the erpetosuchid Tarjadia (redrawn from Ezcurra et al., 2018). D, the aetosaur Desmatosuchus (redrawn from Small, 2002). E, the aetosaur Stagonolepis robertsoni (redrawn from Sulej, 2010). F, the aetosaur Neoaetosauroides (redrawn from Desojo and Báez, 2007). G, the aetosaur Stenomyti huangae (redrawn from Small and Martz, 2013). H, the aetosaur Paratypothorax andressorum (redrawn from Schoch and Desojo, 2016 with modifications, see text). I, the aetosaur Aetosaurus ferratus (redrawn from Schoch, 2007 with modifications, see text). J, the basal phytosaur Diandongosuchus (redrawn from Stocker et al., 2017). K, the loricatan Postosuchus (redrawn from Nesbitt, 2011). L, the loricatan Prestosuchus (based on UFRGS-PV-0152-T and Mastrantonio et al., 2019). M, the ornithosuchid Riojasuchus (redrawn from Bakzco et al., 2018). N, the gracilisuchid Gracilisuchus stipanicicorum (redrawn from Nesbitt, 2011 and observations of Butler et al., 2014). O, the crocodylomorph Dromicosuchus (redrawn from Nesbitt, 2011). Colors indicate bone elements: orange, maxilla; blue, jugal; purple, quadratojugal. Not to scale.

specimens of SMNS 5770 as well (e.g., S-1), although disarticulation, fragmentation, and overpreparation may have obscured it in others (S-2, S4 , S-5, S-7, S-8, S-18, and S-19). The ventral posterior process of the jugal ventral to the quadratojugal was also the condition interpreted by Huene (1920) and Walker (1961) for A. ferratus, indicating that the jugal does not split the quadratojugal as indicated by Nesbitt (2011), Parker (2016a), and most previous authors. Finally, in $A$. ferratus the jugal seems to become proportionally more robust when comparing the smaller (e.g., SMNS 5770 S21) with the larger specimens (e.g., SMNS 5770 S-
16), which may indicate an ontogenetically variable condition.

The condition in Paratypothorax andressorum (SMNS 19003, Figure 20D) is also similar to that of Aetosauroides scagliai. The specimen SMNS 19003 preserves a deformed and slightly disarticulated posterior region of the skull. On the left side, which was used in the original skull description and reconstruction (Schoch and Desojo, 2016, figure 4 and 7a), the jugal is displaced dorsomedially, its posterior portion being almost covered by the laterally displaced quadratojugal and postorbital. On the right side, even 
though the elements are also disarticulated and the jugal has been unnaturally preserved ventromedial to the quadratojugal (Figure 21D), it is possible to see the full extension of the posterior ventral process of the jugal. The disarticulation of the jugal, quadratojugal, and quadrate in several aetosaurs specimens from different taxa may indicate that this area was highly mobile in life.

The ventral posterior portion of the jugal forms the posteroventral corner of the skull in Desmatosuchus smalli (TTUP 9023, Small, 2002; Figure 20E), cf. Aetosaurus ferratus (MCZ 9479R), and probably Neoaetosauroides engaeus (PULR 4363, Figure 20F). The jugal and the quadratojugal are unknown in Stagonolepis olenkae (Sulej, 2010), and the form of articulation with the quadratojugal is unknown in Stagonolepis robertsoni (Walker, 1961). However, in S. robertsoni (Walker, 1961), Coahomasuchus kahleorum (NMMNH P-18496), and Coahomasuchus chathamensis (NCSM 23618), an elongated and posteroventrally projected process of the jugal is present, suggesting that the same condition is present in those taxa. Unfortunately, the jugal and quadratojugal are not well preserved in the almost complete skull of Typothorax coccinarum recently described by Reyes et al. (2020).

Among other pseudosuchians, a long posterior ventral process of the jugal (as observed here in aetosaurs) is shared by phytosaurs (Stocker et al., 2017), gracilisuchids (Butler et al., 2014; Gracilisuchus stipanicicorum, MCZ 4117), erpetosuchids (Olsen et al., 2001; Benton and Walker, 2002; Ezcurra et al., 2017; Foffa et al., 2021), and some loricatans (e.g., Postosuchus kirkipatricki Chatterjee, 1985; Dromicosuchus grallator, NCMS 13733) (Figure 21). This contrasts with the condition in ornithosuchids (e.g., Riojasuchus tenuisceps, according to von Baczko and Desojo, 2016) and some non-crocodylomorph loricatans (e.g., Prestosuchus chiniquensis, UFRGS-PV-0156-T; and Shuvosaurus inexpectatus Chatterjee, 1993, TTUP 9280, Nesbitt, 2011) in which the quadratojugal overhangs the posterior process of the jugal ventrally (Figure 21).

These differences indicate a more complex phylogenetic scenario to be considered in future pseudosuchian studies. For example, although erpetosuchids seem to share a jugal-quadratojugal configuration similar to that of aetosaurs, other putative close relatives do not, such as Revueltosaurus callenderi and Acaenasuchus geoffreyi. The jugal fits into a socket on the quadratojugal in $R$. callenderi (Parker et al., 2005), and in A. geof- freyi the jugal seems to lack a dorsal posterior process and its relationship with the quadratojugal remains unknown (Marsh et al., 2020).

\section{Aetosaur Diet and Paleobiology}

Traditionally, aetosaurs have been considered as one of many putative Late Triassic herbivorous archosaurs, mostly based on their specialized folidont teeth (Figure 22H-K) (Walker, 1961; Parrish, 1994; Heckert and Lucas, 2000; sensu Hendrickx et al., 2015). However, like early sauropodomorphs (e.g., Cabreira et al., 2016; Bronzati et al., 2019) and some silesaurids (e.g., Qvarnström et al., 2019; see Martz and Small, 2019 for a review) that also share folidont teeth (e.g., Dzik, 2003; Cabreira et al., 2016; Pretto et al., 2018; Martz and Small, 2019), aetosaurs have also been interpreted as either omnivorous or faunivorous animals (e.g., Sawin, 1947; Small, 2002; Sulej, 2010; Desojo and Vizcaíno, 2009; Desojo et al., 2013; von Baczko et al., 2018; Brust et al., 2018; Reyes et al., 2021).

One argument in favor of a more faunivorous diet is the presence of recurved ziphodont teeth in Aetosauroides scagliai (according to Casamiquela, 1967; Bonaparte, 1978; Desojo and Ezcurra, 2011; Parker, 2016a; Brust et al., 2018; this study), Coahomasuchus chathamensis (according to Heckert et al., 2017), and Coahomasuchus kahleorum (sensu Parker, 2016a). The teeth in these species are laterally compressed and just slightly constricted at the base or not constricted at all (Figure 22E).

Close aetosaur relatives, like erpetosuchids and ornithosuchids, preserve similar dentitions (e.g., von Baczko and Desojo, 2016; Ezcurra et al., 2017), but folidont teeth with ankylothecodont implantation are present in Revueltosaurus callenderi (Figure 22A) and Acaenasuchus geoffreyi (Marsh et al., 2020; Figure 22B), two of the three taxa forming the clade recently recovered as the sister group of Aetosauria (Marsh et al., 2020). In that study, the common ancestor of erpetosuchids, $R$. callenderi, and aetosaurs was interpreted as a small, carnivorous pseudosuchian, but the ancestor of $R$. callenderi and aetosaurs was likely omnivorous, implying that ziphodont or folidont dentition may have been acquired independently in aetosaurs. Resolution of ancestral states for these nodes will require broader phylogenetic study, beyond the scope of the current contribution.

Most stagonolepidid aetosaurs have folidont to more bulbous teeth (Figure $22 \mathrm{H}-\mathrm{K}$ ) and, with the exception of Typothorax coccinarum (Reyes et al., 
A

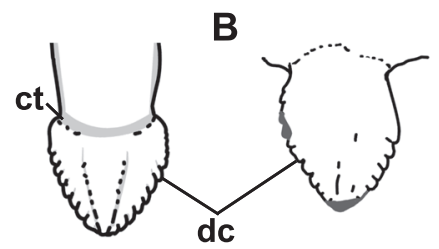

E
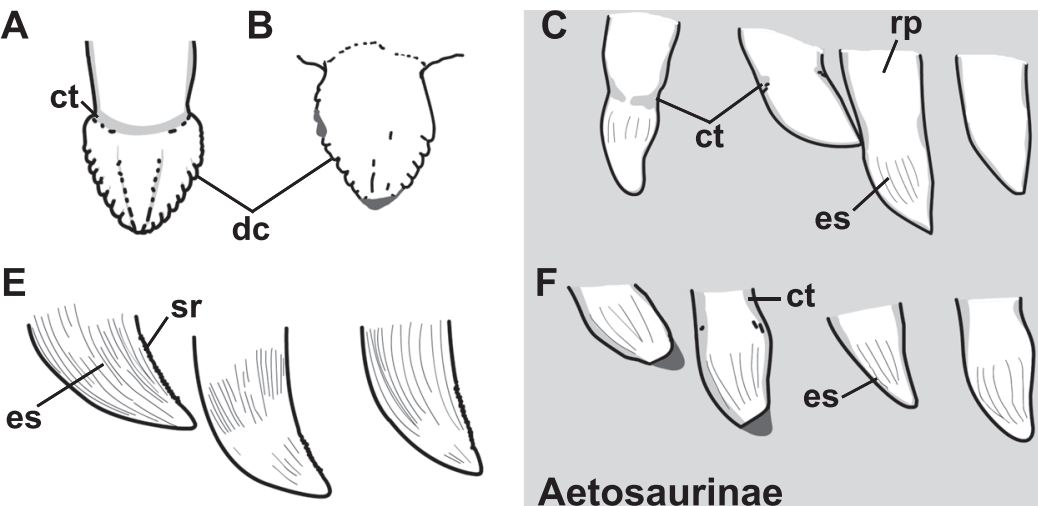

Aetosaurinae

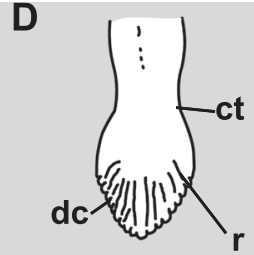

G
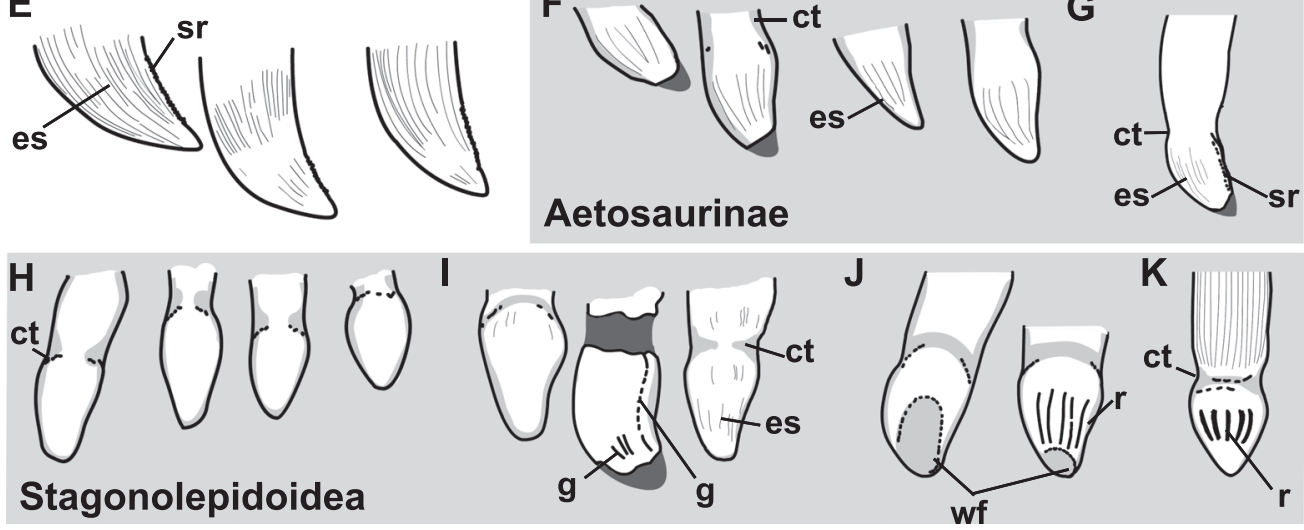

FIGURE 22. Maxillary teeth diversity of Revueltosaurus callenderi (A, based in PEFO 34561), Acaenasuchus geoffreyi (B, based in Marsh et al., 2020), and Aetosauria: C, Paratypothorax andressorum (SMNS 19003, mirrored). D, Typothorax coccinarum (based in Reyes et al., 2021). E, Aetosauroides scagliai (UFSM 11505). F, Aetosaurus ferratus (SMNS 5772 S-18). G, c.f. Stenomyti huangae (DMNH 60708). H, Neoaetosauroides engaeus (PULR 108). I, Desmatosuchus smalli (TTUP 9420); J, Stagonolepis robertsoni (ELGNM 38, mirrored); K, Stagonolepis olenkae (ZPAL AbIII 2752). Abbreviations: ct, constriction of the base; dc, large denticles; es, enamel striations (faint gray line); g, grooves or flutes (black line); r, ridge (bold black line); rp, resorption pit; t, longitudinal ridge; wf, wear facet.

2021), differ from Revueltosaurus callenderi (Figure 22A), Acaenasuchus geoffreyi (Figure 22B), and other previously mentioned groups by lacking serrated carinae (e.g., Walker, 1961; Reyes et al., 2021). As pointed out by Reyes et al. (2021), however, rather than being homogeneous, aetosaurs present a considerable amount of disparity in tooth morphology. Some aetosaurs are known to have a degree of heterodonty, including variation in the morphology of the distal tooth margin (Schoch, 2007; Brust et al., 2018; Reyes et al., 2020). Several features related to specializations of the crown surfaces are also present (Desojo and Báez, 2007; Schoch and Desojo, 2016; Brust et al., 2018; Reyes et al., 2021). For instance, enamel striations were reported in Paratypothorax andressorum (Schoch and Desojo, 2016; Figure 22C), Aetosauroides scagliai (Brust et al., 2018; Figure 22E), Stagonolepis olenkae (Sulej, 2010; Figure 22K), and Coahomasuchus chathamensis (NCSM 23618), but seem to be absent in Stagonolepis robertsoni (ELGNM 38). Also, some taxa preserve ridges or striations (e.g., S. robertsoni, ELGNM 38; Figure 22J) and grooves (e.g., D. smalli, TTU P9420; Figure 22I; T. coccinarum, 'flutes' of Reyes et al., 2021; Figure 22D), which alter the tooth surface.
Diminutive serrations or denticles are reported in Aetosauroides scagliai (Brust et al., 2018; Figure 22E), Stagonolepis robertsoni (Walker, 1961), S. olenkae (Sulej, 2010), Desmatosuchus smalli (Small, 2002), and Typothorax coccinarum (Reyes et al., 2020; Figure 23D). These have been reported as absent in some aetosaurines, such as Aetosaurus ferratus, Paratypothorax andressorum, and Stenomyti huangae (e.g., Schoch, 2007; Small and Martz, 2013; Schoch and Desojo, 2018). However, this absence must be considered carefully, as aetosaur teeth are not usually well-preserved or carefully prepared. The serrations are usually reduced in size (with more than 5 per $1 \mathrm{~mm}$ ) and are reported to be restricted to some portions of the teeth in some species (e.g., A. scagliai, Brust et al., 2018; and T. coccinarum, Reyes et al., 2021). As pointed out by Walker (1961) for S. robertsoni (Figure 22J), the serrations are so diminutive that they could be eroded through life, or removed by tooth wear, as occurs in some taxa (Walker, 1961; Small, 2002; S. huangae, DMNH 60708). As evidence of this, a probable isolated tooth of $S$. huangae (DMNH 42493, Figure 22G) preserves serrations, although as observed by Small and Martz (2013), they are lacking in the type material of that species. 


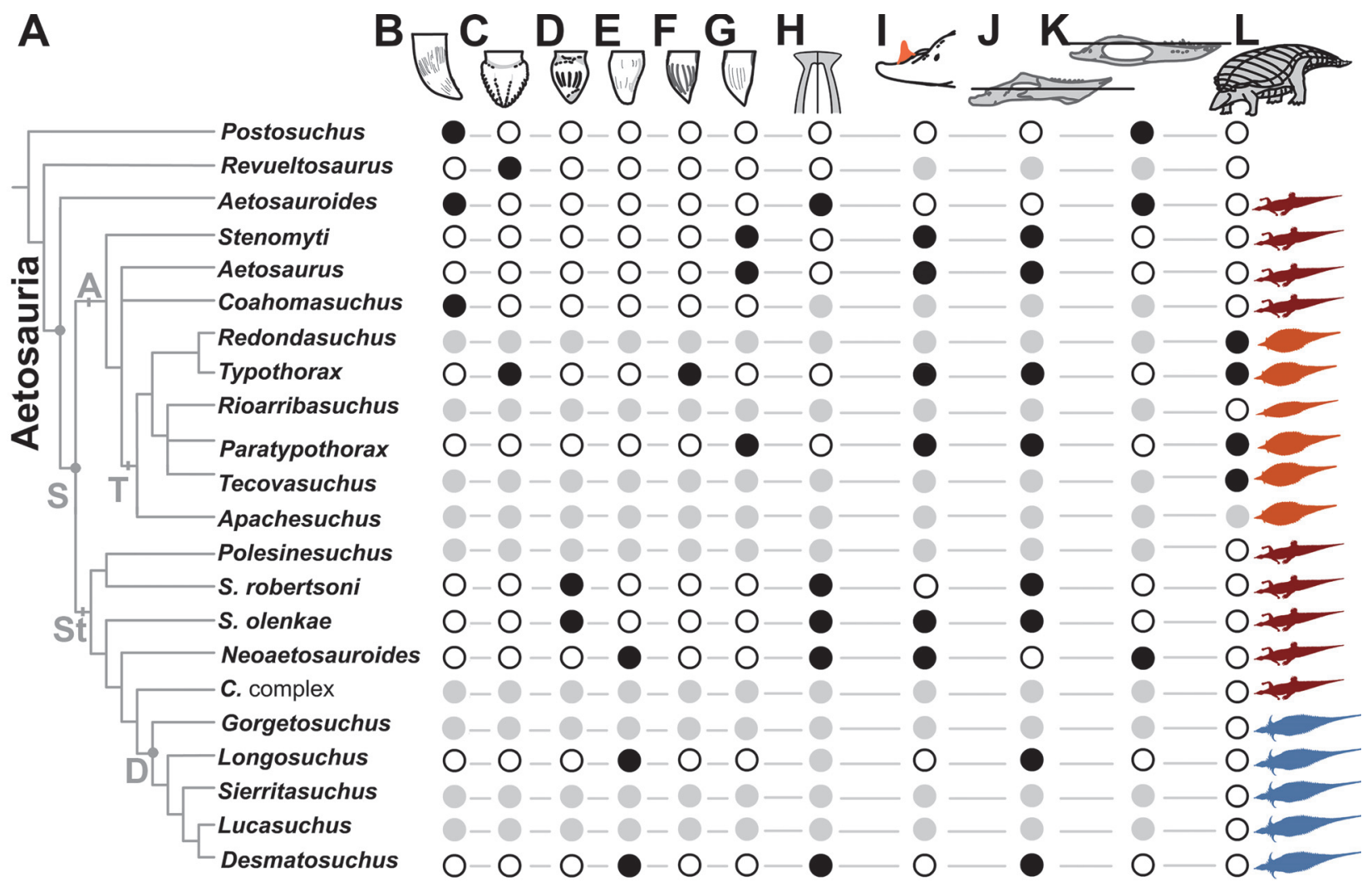

FIGURE 23. Morphological features related to feeding strategies in Aetosauria in a phylogenetic perspective. A, simplified genus level phylogeny of Reyes et al. (2020). We coalesced the clade formed by Calyptosuchus, Adamanasuchus and Scutarx (C. complex) as no dental information is available for these taxa and they all share the same overall body-shape. B, ziphodont teeth. C, folidont teeth with marked serrations. D, folidont tooth with tooth wear. E, elongated folidont teeth with tooth wear. F, folidont to bulbous teeth with grooves/flutes. G, bulbous teeth with enamel striations. $\mathrm{H}$, shovel-shaped premaxilla. I, medial dorsal process of the articular; J, glenoid placed ventral to the tooth line in the mandible. $\mathrm{K}$, glenoid placed near or dorsal to the teeth line in the mandible. L, wide-body morphology indicating large gastric cavities. Dark circles indicate presence, white circles indicate absence and gray circles indicate missing data. Silhouettes at the right side show the overall body shape of aetosaurs as suggested by Desojo et al. (2013), in red the 'narrow-body', in orange the 'wide-body' and in blue the 'spinose'. Abbreviations: A, Aetosaurinae; D, Desmatosuchini; S, Stagonolepididae; St, Stagonolepidoidea; T, Typothoracinae.

The absence of folidont teeth does not necessarily support a strictly faunivorous diet for Aetosauroides scagliai. Diet inference for extinct vertebrates is a complex field of research relying on several associated but independent lines of evidence (e.g., Reisz and Sues, 2000). Several osteological features of aetosaurs have been considered as diet informative, such as the edentulous anterior premaxilla and dentary and the shovel-shaped premaxillary tip (Parrish, 1994; Small, 2002; Desojo et al., 2013; Figure $23 \mathrm{H}$ ) present in $A$. scagliai. These features have been interpreted as useful for "digging or grubbing amongst soft vegetation" (Walker, 1961 , p. 193), congruent with the idea that aetosaurs used their limbs to dig (Walker, 1961; Heckert and Lucas, 2010; Dróżdż, 2018).
Desojo and Vizcaíno (2009) observed disparity in biomechanical aspects of the mandible of some aetosaurs, including the placement of the glenoid (Figure 23J-K). Interestingly, the mandibular articulation of $A$. scagliai is placed at the tooth level, contrasting with that of most other aetosaurs, in which it is placed more ventrally (see Desojo and Vizcaíno, 2009). However, it is similar to the condition found in Neoatosauroides engaeus, which does not have ziphodont teeth (Desojo and Báez, 2007; Desojo and Vizcaíno, 2009; Desojo et al., 2013; Figure 22H). Curiously, although a keratinous beak has been suggested for many aetosaurs (based in the strongly curved dentary associated with numerous neurovascular foramina at the edentulous region of the premaxilla and den- 
tary; see, e.g., Parrish, 1994; Holliday and Nesbitt, 2013; Wynd et al., 2020), it seems to have been absent in N. engaeus (Desojo, 2005; Desojo and Báez, 2007). Most non-aetosaurine aetosaurs lack a tall, thorn-like dorsal process on the articular (Figure 23I), which may have provided additional attachment sites for the M. depressor mandibulae (sensu Desojo and Vizcaíno, 2009), thus revealing further disparity of retroarticular process shape of aetosaurs (Figure 23I). In this regard, Aetosauroides scagliai is more similar to non-aetosaurine aetosaurs due to the presence of the shovelshaped premaxilla (Brust et al., 2018; Reyes et al., 2021) associated with the absence of a dorsal process in the articular (Figure 23I). These differences may indicate differences in food item selectivity between aetosaurine aetosaurs and other members of the group (see also Reyes et al., 2021). Furthermore, some aetosaurines preserve large gastric cavities (e.g., Heckert et al., 2010; Desojo et al., 2013; Schoch and Desojo, 2016; Figure $23 \mathrm{~L}$ ), an important condition related to herbivory (Reisz and Sues, 2000), despite the lack of serrated-folidont teeth (e.g., Paratypothorax andressorum, Schoch and Desojo, 2016).

In sum, the skull of Aetosauroides scagliai is generally more similar than previously thought to that of other aetosaurs, presenting a mosaic of characters of Stagonolepidoidea and Aetosaurinae. Like Desojo et al. (2013) and Reyes et al. (2020), we argue that trophic character-related variation within Aetosauria (e.g., teeth morphology, lack of acute dorsal process of the articular, the presence of shovel-shaped premaxilla, and small gastric cavity) indicates that they were able to explore a range of feeding strategies during their evolution. Variation in these anatomical features may indicate more faunivorous or herbivorous feeding habits among different lineages, with Aetosauroides scagliai and other taxa with ziphodont teeth probably having a more faunivorous diet. On the other hand, more strictly herbivorous members of the clade may have independently evolved within Stagonolepidoidea (e.g., Desmatosuchus) and Typothoracinae (e.g., Paratypothorax), but potentially exploring different food items (see also Reyes et al., 2021). Interestingly, aetosaurs were changing their ancestral faunivorous feeding strategy concomitantly with the coeval sauropodomorph dinosaurs (e.g., Cabreira et al., 2016; Müller et al., 2018).

\section{CONCLUSION}

A detailed description of the skull osteology of the aetosaur Aetosauroides scagliai, an important member of the Carnian-Norian fauna of South America, is presented based on new records from Brazil. The newly added morphological information has permitted a more complete understanding of A. scagliai on a broad comparative level and elucidated several previously problematic aspects of its anatomy. An elongated posterior process of the jugal forms the posteroventral corner of its skull, a condition demonstrated here to be shared with all known aetosaurs and with some other pseudosuchians (e.g., phytosaurs, gracilisuchids, erpetosuchids, and several crocodylomorphs), but not with supposedly more closely related lineages (e.g., Revueltosaurus and ornithosuchids). Additionally, unlike most other aetosaurs, A. scagliai lacks a pneumatic cavity on the medial surface of the maxilla, it has at least 12 dentary teeth, and the mandibular joint is placed at the level of the tooth line. Despite these features and the presence of recurved teeth, typical of more faunivorous animals, several features with other aetosaurs (e.g., shovel-shaped premaxilla; edentulous anterior region of the premaxilla and dentary) indicate that A. scagliai was probably an omnivore. Clear variation in aetosaur jaw and tooth morphology indicates that dietary range in this clade is likely underappreciated, and more research on the functional and paleobiological implications of this variation is needed.

\section{ACKNOWLEDGMENTS}

V.D.P.N was supported by a PhD CNPq grant (140449/2016-7), a scholarship of CAPES (PDSE88881.187108/2018-01), a Deutscher Akademischer Austauschdienst Short-term grant (2017) and a Doris O. and Samuel P. Welles Research Fund (2018). J.B.D. was supported by a PICT 2018-0717; CNPq supported C.L.S. (307711/20170); A.M.R. (306951/2017-7); and M.B.S. (307938/ 2019-0). FAPERJ also supported M.B.S. (EE-26/ $010.002178 / 2019$ ). We are grateful to J. Ferigolo (MCN-PV), Á. Da-Rosa (UFSM), and M. Brandalise (MCP) for access to the studied specimens. We also thank N. Thomaz, P.L. Oliveira, and V. Eschiletti for digital preparation of the specimens. We thank A. Augustin, M. Vianna, and their team for the usage of the microtomographer of the Laboratório de Sedimentologia e Petrologia of the Pontifícia Universidade Católica. We also thank A. Rountrey (UMMP), B. Mueller (TTUP), C. Lash 
(PEFO), C. Apaldetti (PVSJ), C. Sagebiel (TMM), C. Mejia (UCMP), C. Kammerer (NCSM), D. Brinkman (YPM), D. Gillette (MNA), D. Gower (The Natural History Museum, UK), D. Longstaff (ELGM), H-D Sues (USNM), I. Werneburg (GPIT), J. Hinz (GPIT), J. Gillette (MNA), J. Trythall (ELGM), J. Cundiff (MCZ), J. Sertich (DMNH), K. Bader (TMM), K. Mackenzie (DMNH), M. Tałanda (ZPAL AbllI), M. Wosik (NMMNH), M. Smith (PEFO), N. Ridgwell (NMMNH), G. Cisterna (PULR), P. Ortiz (PVL), P. Holroyd (UCMP), R. Schoch (SMNS), R. Martinez (PVSJ), R. González (PVL), S. Chatherjee (TTUP), S. Lucas (NMMNH), S. Walsh (NMS), T. Sulej (ZPAL AbIII), and W. Parker (PEFO) for turning possible comparisons with specimens under their care. We thank the handling editor C.F. Kammerer, the four anonymous reviewers, W. Parker (PEFO), P.H. Fonseca (UFRGS), A. Martinelli (MACN), M. Lacerda (UFRGS), M.A.G. de França (Universidade Federal do Vale do São Francisco, Brazil), D. Drósżdż (ZPAL AblII), F. Pinheiro (UNIPAMPA), M.B. Martins (UFRGS), M. Ezcurra (MACN), L. Roberto-da-Silva, and M. Belen von Baczko (MACN) for their comments on the earlier drafts of this paper and discussions that helped to improve it. Special thanks to M. Proença, M.C. Langer, M. Hechenleitner, L. Fiorelli, F. Abdala, A. and R. Escobár, J. and D. Gillette, Y. Huang and B. Small, E. Pelka, and PEFO members for making this research possible.

\section{REFERENCES}

Agassiz, L. 1844. Monographie des poissons fossiles du Vieux Grès Rouge ou Système Dévonien (Old Red Sandstone) des îles Britanniques et de Russie. Jent et Gassman, Neuchatel.

Antczak M., 2016. Late Triassic aetosaur (Archosauria) from Krasiejów (SW Poland) - new species or an example of individual variety? Geological Journal, 51:779-788. https://doi.org/ 10.1002/gj.2691

Arcucci, A. and Marsicano, C.A. 1998. A distinctive new archosaur from the Middle Triassic (Los Chañares Formation) of Argentina. Journal of Vertebrate Paleontology, 18:228-232. https://doi.org/10.1080/02724634.1998.10011046

Benton, M. and Walker, A.D. 2002. Erpetosuchus, a crocodile-like basal archosaur from the Late Triassic of Elgin, Scotland. Biological Journal of the Linnean Society, 136:25-47. https://doi.org/10.1046/j.1096-3642.2002.00024.x

Bonaparte, J.F. 1969. Los tetrápodos triásicos de Argentina. $1^{\circ}$ International Symposium of Gondwana, Mar del Plata, p. 307.

Bonaparte, J.F. 1971a. Los tetrapodos del sector superior de la Formacion Los Colorados, La Rioja, Argentina. (Triasico Superior). Opera Lilloana, 22:1-183.

Bonaparte, J.F. 1973. Edades/Reptil para el Triasico de Argentina y Brasil. $5^{\circ}$ Congreso Geológico Argentino, 3:93-129.

Bonaparte, J.F. 1978. El Mesozoico de América del Sur y sus tetrápodos. Opera Lilloana, 26:1596.

Bronzati, M., Müller, R.T., and Langer, M.C. 2019. Skull remains of the dinosaur Saturnalia tupiniquim (Late Triassic, Brazil): With comments on the early evolution of sauropodomorph feeding behaviour. PLoS ONE, 14(9):e0221387. https://doi.org/10.1371/journal.pone.0221387

Brusatte, S.L., Benton, M.J., Desojo, J.B., and Langer, M.C. 2010. The higher-level phylogeny of Archosauria (Tetrapoda: Diapsida). Journal of Systematic Palaeontology, 8:3-47. https://doi.org/10.1080/14772010903537732

Brust, A.C., Desojo, J.B, Schultz, C.L., Paes-Neto, V.D., and Da-Rosa, A.A.S. 2018. Osteology of the first skull of Aetosauroides scagliai Casamiquela 1960 (Archosauria: Aetosauria) from the Upper Triassic of southern Brazil (Hyperodapedon Assemblage Zone) and its phylogenetic importance. PLoS ONE, 13(8):e0201450. https://doi.org/10.1371/journal.pone.0201450

Butler, R.J., Sulivan, C., Ezcurra, M.D., Lecuona, A., and Sookias, R.B. 2014. New clade of enigmatic early archosaurs yields insights into early pseudosuchian phylogeny and the biogeography of the archosaur radiation. BMC Evolutionary Biology, 14(128):1-16. https://doi.org/10.1186/1471-2148-14-128 
Butler, R.J., Nesbitt, S.J., Charig, A.J., Gower, D.J., and Barrett, P.M. 2017. Mandasuchus tanyauchen, gen. et sp. nov., a pseudosuchian archosaur from the Manda Beds (? Middle Triassic) of Tanzania. Journal of Vertebrate Paleontology, 37(sup1):96-121. https://doi.org/10.7934/p3249

Cabreira, S.F., Kellner, A.W.A., Dias-da-Silva, S., Roberto-da-Silva, L.R., Bronzati, M., de Almeida Marsola, J.C., Müller, R.T., Bittencourt, J.S., Batista, B.J., Raugust, T., Carrilho, R., Brodt, A., and Langer, M.C. 2016. A unique Late Triassic dinosauromorph assemblage reveals dinosaur ancestral anatomy and diet. Current Biology, 26:3090-3095. https://doi.org/10.1016/j.cub.2016.09.040

Casamiquela, R.M. 1960. Noticia preliminar sobre dos nuevos estagonolepoideos Argentinos. Amenghiniana, 2:3-9.

Casamiquela, R.M. 1961. Dos nuevos estagonolopoideos Argentinos (de Ischigualasto, San Juan). Revista de la Asociación Geológica de Argentina, 16:143-203.

Casamiquela, R.M. 1967. Materiales adicionales y reinterpretación de Aetosauroides scagliai (de Ischigualasto, San Juan). Revista del Museo de La Plata (nueva serie), Tomo 5, Sección Paleontología, 33:173-196.

Case, E.C. 1920. Preliminary description of a new suborder of phytosaurian reptiles with a description of a new species of Phytosaurus. Journal of Geology, 28:28-535. https://doi.org/10.1086/622732

Case, E.C. 1922. New reptiles and stegocephalians from the Upper Triassic of western Texas. Carnegie Institution of Washington Publication, 321:1-84.

Cerda, I.A. and Desojo, J.B. 2011. Dermal armour histology of Aetosaurinae Aetosauroides (Archosauria: Pseudosuchia) from the Upper Triassic of Argentina and Brazil. Lethaia, 44:417-428.

Cerda, I.A., Desojo, J.B., and Scheyer, T.M. 2018. Novel data on aetosaur (Archosauria, Pseudosuchia) osteoderm microanatomy and histology: palaeobiological implications. Palaeontology, 61(5):721-745.

Chatterjee, S. 1993. Shuvosaurus, a new theropod. National Geographic Research and Exploration, 9:274-285.

Cope, E.D. 1869. Synopsis of the extinct Batrachia, Reptilia and Aves of North America. Transactions of the America Philosophical Society, 14:1-252.

Cope, E.D. 1875. Report on the geology of that part of northwestern New Mexico examined during the field-season of 1874. Annual Report upon the geographical explorations west of the 100th Meridian [Wheeler Survey], Appendix LL, Annual Report Chief of Engineers for 1875, p. 981-1017.

Czepiński, Ł., Dróżdż, D., Szczygielski, T., Tałanda, M., Pawlak, W., Lewczuk, A., Rytel, A., and Sulej, T. 2021. An Upper Triassic terrestrial vertebrate assemblage from the Forgotten Kocury locality (Poland) with a new aetosaur taxon. Journal of Vertebrate Paleontology, 41:e1898977. https://doi.org/10.1080/02724634.2021.1898977

Da-Rosa, A.A.S and Leal, L.A. 2002. New elements of an armored archosaur from the Middle to Upper Triassic, Santa Maria Formation, south of Brazil. Arquivos do Museu Nacional, 60:149-154.

Desojo, J.B. 2005. Los Aetosaurios (Amniota, Diapsida) de America del Sur: sus relaciones y aportes a la biogeografia y bioestratigrafia del Triasico continental. Unpublished PhD thesis, Universidad de Buenos Aires Facultad de Ciencias Exactas y Naturales, Buenos Aires, Argentina.

Desojo, J.B. and Heckert, A.B. 2004. New information on the braincase and mandible of Coahomasuchus (Archosauria: Aetosauria) from the Otischalkian (Carnian) of Texas. Neues Jahrbuch für Geologie und Paläontologie, Monatshefte, 2004(10):605-616. https://doi.org/10.1127/njgpm/2004/2004/605

Desojo, J.B. and Báez, A.M. 2007. Cranial morphology of the Late Triassic South American archosaur Neoaetosauroides engaeus: evidence for aetosaurian diversity. Palaeontology, 50:267-276. https://doi.org/10.1111/j.1475-4983.2006.00608.x

Desojo, J.B. and Vizcaíno, S.F. 2009. Jaw biomechanics in the South American aetosaur Neoaetosauroides engaeus. Paläontologische Zeitschrift, 83:499-510. https://doi.org/10.1007/s12542-009-0032-6 
Desojo, J.B. and Ezcurra, M.D. 2011. A reappraisal of the taxonomic status of Aetosauroides (Archosauria, Aetosauria) specimens from the Late Triassic of South America and their proposed synonymy with Stagonolepis. Journal of Vertebrate Paleontology, 31:596-609. https://doi.org/10.1080/02724634.2011.572936

Desojo, J.B., Ezcurra, M.D., and Schultz, C.L. 2011. An unusual new archosauriform from the Middle-Late Triassic of southern Brazil and the monophyly of Doswelliidae. Zoological Journal of the Linnean Society, 161:839-871. https://doi.org/10.1111/j.1096-3642.2010.00655.x

Desojo, J.B., Ezcurra, M.D., and Kischlat, E.E. 2012. A new aetosaur genus (Archosauria: Pseudosuchia) from the early Late Triassic of southern Brazil. Zootaxa, 3166:1-33. https://doi.org/10.11646/zootaxa.3166.1.1

Desojo, J.B., Heckert, A.B., Martz, J.W., Parker, W.G., Schoch, R.R., Small, B.J., and Sulej, T. 2013. Aetosauria: a clade of armoured pseudosuchians from the Upper Triassic continental beds. In Nesbitt, S.J., Desojo, J.B., and Irmis, R.B. (eds.), Anatomy, Phylogeny and Palaeobiology of Early Archosaurs and their Kin. Geological Society, London, Special Publications, 379:203-239. https://doi.org/10.1144/SP379.17

Desojo, J.B., von Baczko, M.B., and Rauhut, O.W.M. 2020a. Anatomy, taxonomy and phylogenetic relationships of Prestosuchus chiniquensis (Archosauria: Pseudosuchia) from the original collection of von Huene, Middle-Late Triassic of southern Brazil. Palaentologia Electronica, 23:a04. https://doi.org/10.26879/1026

Desojo, J.B., Fiorelli, L.E., Ezcurra, M.D., Martinelli, A.G., Ramezani, J., Da Rosa, A.A. S., von Baczko, M.B., Trotteyn, M.J., Montefeltro, F.C., Ezpeleta, M., Langer, M.C. 2020b. The Late Triassic Ischigualasto Formation at Cerro Las Lajas (La Rioja, Argentina): fossil tetrapods, high-resolution chronostratigraphy, and faunal correlations. Scientific Reports, 10(1):1-34.

Dróżdż, D. 2018. Osteology of a forelimb of an aetosaur Stagonolepis olenkae (Archosauria: Pseudosuchia: Aetosauria) from the Krasiejów locality in Poland and its probable adaptations for a scratch-digging behavior. PeerJ, 6:e5595. https://doi.org/10.7717/peerj.5595

Dzik, J. 2001. A beaked herbivorous archosaur with dinosaur affinities from the early Late Triassic of Poland. Journal of Vertebrate Paleontology, 23:556-574.

Ezcurra, M.D. 2016. The phylogenetic relationships of basal archosauromorphs, with an emphasis on the systematics of proterosuchian archosauriforms. PeerJ, 4:e1778. https://doi.org/10.7717/peerj.1778

Ezcurra, M.D., Fiorelli, L.E., Martinelli, A.G., Rocher, S., von Baczko, M.B., Ezpeleta, M., Taborda, J.R.A., Hechenleitner, E.M., Trotteyn, M.J., and Desojo, J.B. 2017. Deep faunistic turnovers preceded the rise of dinosaurs in southwestern Pangaea. Nature Ecology and Evolution, 1:1477-1483. https://doi.org/10.1038/s41559-017-0305-5

Foffa, D., Butler, R.J., Nesbitt, S.J., Walsh, S., Barrett, P.M., Brusatte, S.L., and Fraser, N.C. 2020. Revision of Erpetosuchus (Archosauria: Pseudosuchia) and new erpetosuchid material from the Late Triassic 'Elgin Reptile' fauna based on $\mu C T$ scanning techniques. Earth and Environmental Science Transactions of The Royal Society of Edinburgh, 111(4):209-233. https://doi.org/10.1017/S1755691020000109

Fraas, O. 1877. Aetosaurus ferratus Fr. Die gepanzerte Vogel-Echse aus dem Stubensandstein bei Stuttgar. Festschrift zur Feier des 400jährigen Jubiläums der Eberhard-Karls-Universät zu Tübingen, Wurttembergische Naturwissenschaftliche Jahreshefte, 33:1-22.

Garcia, M.S., Pretto, F.A., Dias-da-Silva, S., and Müller, R.T. 2019. A dinosaur ilium from the Late Triassic of Brazil with comments on key-character supporting Saturnaliinae. Anais da Academia Brasileira de Ciências, 91(Suppl. 2):e20180614. https://doi.org/10.1590/0001-3765201920180614

Gauthier, J. and Padian, K. 1985. Phylogenetic, functional, and aerodynamic analyses of the origin of birds and their flight, p. 185-197. In Hecht, M.K. (ed.), The Beginning of Birds. Freunde des Jura Museums, Eichstatt.

Gower, D.J. and Walker, A.D. 2002. New data on the braincase of the aetosaurian archosaur (Reptilia: Diapsida) Stagonolepis robertsoni Agassiz. Zoological Journal of the Linnean Society, 136:7-23. https://doi.org/10.1046/j.1096-3642.2002.00023.x

Harris, S.R., Gower, D.J., and Wilkinson, M. 2003. Phylogenetic methods and aetosaur interrelationships: a rejoinder. Systematic Biology, 52:851.

https://doi.org/10.1093/sysbio/52.6.851 
Heckert, A.B. and Lucas, S.G. 1999. A new aetosaur (Reptilia: Archosauria) from the Upper Triassic of Texas and the phylogeny of aetosaurs. Journal of Vertebrate Paleontology, 19:5068. https://doi.org/10.1080/02724634.1999.10011122

Heckert, A.B. and Lucas, S.G. 2000. Taxonomy, phylogeny, biostratigraphy, biochronology, paleobiogeography, and evolution of the Late Triassic Aetosauria (Archosauria: Crurotarsi). Zentralblattfür Geologie und Paläontologie Teil I 1998. Heft 11-12:1539-1587.

Heckert, A.B. and Lucas, S.G. 2002. South American occurrences of the Adamanian (Late Triassic: latest Carnian) index taxon Stagonolepis (Archosauria: Aetosauria) and their biochronological significance. Journal of Paleontology, 76:852-8631. https://doi.org/10.1666/0022-3360(2002)076<0852:SAOOTA>2.0.CO;2

Heckert, A.B., Hunt, A.P., and Lucas, S.G. 1996. Redescription of Redondasuchus reseri, a Late Triassic aetosaur (Reptilia: Archosauria) from New Mexico (U.S.A.), and the biochronology and phylogeny of aetosaurs. Geobios, 29:619-632. https://doi.org/10.1016/S0016-6995(96)80028-3

Heckert, A.B., Fraser, N.C., and Schneider, V.P. 2017. A new species of Coahomasuchus (Archosauria, Aetosauria) from the Upper Triassic Pekin Formation, Deep River Basin, North Carolina. Journal of Paleontology, 91:162-178. https://doi.org/10.1017/jpa.2016.130

Heckert, A.B., Lucas, S.G., Hunt, A.P., and Spielmann, J.A. 2007. Late Triassic aetosaur biochronology revisited. In Lucas, S.G. and Spielmann, J.A. (eds.), The Global Triassic. New Mexico Museum of Natural History and Science Bulletin, 41:49-50.

Heckert, A.B., Lucas, S.G., Rinehart, L.F., Celeskey, M.D., Spielmann, J.A., and Hunt, A.P. 2010. Articulated skeletons of the aetosaur Typothorax coccinarum Cope (Archosauria: Stagonolepididae) from the Upper Triassic Bull Canyon Formation (Revueltian: early-mid Norian), eastern New Mexico, USA. Journal of Vertebrate Paleontology, 30:619-642. https://doi.org/10.1080/02724631003763524

Hendrickx, C., Mateus, O., and Araújo, R. 2015. A proposed terminology of theropod teeth (Dinosauria, Saurischia). Journal of Vertebrate Paleontology, 35:e982797. https://doi.org/10.1080/02724634.2015.982797

Hoffman, D.K., Heckert, A.B., and Zanno, L.E. 2018. Under the armor: X-ray computed tomographic reconstruction of the internal skeleton of Coahomasuchus chathamensis (Archosauria: Aetosauria) from the Upper Triassic of North Carolina, USA, and a phylogenetic analysis of Aetosauria. PeerJ, 6:e4368.

Hoffman, D.K., Heckert, A.B., and Zanno, L.E. 2019. Disparate growth strategies within Aetosauria: novel histologic data from the aetosaur Coahomasuchus chathamensis. The Anatomical Record (Hooken), 302:1504-1515. https://doi.org/10.1002/ar.24019

Holliday, C.M. and Witmer, L.M. 2008. Cranial kinesis in dinosaurs: intracranial joints, protractor muscles, and their significance for cranial evolution and function in diapsids. Journal of Vertebrate Paleontololgy, 28:1073-1088. https://doi.org/10.1671/0272-4634-28.4.1073

Holliday, C.M. and Nesbitt, S.J. 2013. Morphology and diversity of the mandibular symphysis of archosauriforms. In Nesbitt, S.J., Desojo, J.B., and Irmis, R.B. (eds.), Anatomy, Phylogeny and Palaeobiology of Early Archosaurs and their Kin. Geological Society, London, Special Publications, 379:555-571.

Horn, B.L.D., Melo, T.M., Schultz, C.L., Philipp, R.P., Kloss, H.P., and Goldberg, K. 2014. A new third-order sequence stratigraphic framework applied to the Triassic of the Paraná Basin, Rio Grande do Sul, Brazil, based on structural, stratigraphic and paleontological data. Journal of South American Earth Sciences, 55:123-132. https://doi.org/10.1016/j.jsames.2014.07.007

Huene, F. 1920. Osteologie von Aëtosaurus ferratus O. Fraas. Acta Zoologica, 1:465-491.

Huene, F. 1938. Die fossilen Reptilien des südamerikanischen Gondwanalandes. Neues Jarhbuch für Mineralogie, Geologie und Paläontologie, 142-151.

Hunt, A.P. 1989. A new ?ornithischian dinosaur from the Bull Canyon Formation (Upper Triassic) of east-central New Mexico, p. 355-358. In Lucas, S.G. and Hunt, A.P. (eds.), Dawn of the Age of Dinosaurs in the American Southwest. New Mexico Museum of Natural History and Science, Albuquerque.

Jenisch, A.G., Lehn, I., Gallego, O.F., Monferran, M.D., Horodyski, R.S., and Faccini, U.F. 2017. Stratigraphic distribution, taphonomy and paleoenvironments of Spinicaudata in the Triassic and Jurassic of the Paraná Basin. Journal of South American Earth Sciences, 80:569-588. https://doi.org/10.1016/j.jsames.2017.09.022 
Jenkins, F.A.Jr., Shubin, N.H., Amaral, W.W., Gatesy, S.M., Schaff, C.R., Clemmensen, L.B., Downs, W.R., Davidson, A.R., Bonde, N. and Osbæk, F. 1994. Late Triassic continental vertebrates and depositional environments of the Fleming Fjord Formation, Jameson Land, East Greenland. Meddelelser om Grønland Geoscience, 32:1-25.

Lacerda, M.B., de França, M.A.G., and Schultz, C.L. 2018. A new erpetosuchid (Pseudosuchia, Archosauria) from the Middle-Late Triassic of Southern Brazil. Zoological Journal of the Linnean Society, 184:804-824. https://doi.org/10.1093/zoolinnean/zly008

Langer, M.C., Ribeiro, A.M., Schultz, C.L., and Ferigolo, J. 2007. The continental tetrapodbearing Triassic of south Brazil. In Lucas, S.G. and Spielmann, J.A, (eds.), The Global Triassic. New Mexico Museum of Natural History and Science Bulletin, 41:201-218.

Langer, M.C., Ramezani, L., and Da Rosa, A.A.S. 2018. U-Pb age constraints on dinosaur rise from south Brazil. Gondwana Research, 57:133-140. https://doi.org/10.1016/j.gr.2018.01.005

Lecuona, A. 2013. Anatomía y relaciones filogenéticas de Gracilisuchus stipanicicorum y sus implicancias en el origen de Crocodylomorpha. Unpublished PhD thesis, Universidad de Buenos Aires, Buenos Aires, Argentina.

Long, R.A. and Ballew, K.L. 1985. Aetosaur dermal armor from the Late Triassic of southwestern North America, with special reference to material from the Chinle Formation of Petrified Forest National Park. In Colbert, E.H. and Johnson, R.R. (eds.), The Petrified Forest Through the Ages, 75th Anniversary Symposium, 1981. Museum of Northern Arizona Bulletin, 54:45-68.

Long, R.A. and Murry, P.A. 1995. Late Triassic (Carnian and Norian) tetrapods from the southwestern United States. New Mexico Museum of Natural History and Science Bulletin, 4:1-254.

Lucas, S.G. 1998. Global Triassic tetrapod biostratigraphy and biochronology. Paleogeography, Paleoclimatology, Paleoecology, 143:347-384.

Lucas, S.G. and Heckert, A.B. 2001. The aetosaur Stagonolepis from the Upper Triassic of Brazil and its biochronological significance. Neues Jahrbuch fur Geologie und Palaontologie, Monatshefte, 2001:719-732. https://doi.org/10.1127/njgpm/2001/2001/719

Lucas, S.G. and Heckert, A.B. 2002. The Hyperodapedon Biochron, Late Triassic of Pangea. Albertiana, 27:30-38.

Lucas, S.G., Heckert, A.B., and Huber, P. 1998. Aetosaurus (Archosauromorpha) from the Upper Triassic of the Newark Supergroup, eastern United States, and its biochronological significance. Paleontology, 41:1215-1230.

Maisch, M.W., Matzke, A.T., and Rathgeber, T. 2013. Re-evaluation of the enigmatic archosaur Dyoplax arenaceus O. Fraas, 1867 from the Schilfsandstein (Stuttgart Formation, lower Carnian, Upper Triassic) of Stuttgart, Germany. Neues Jahrbuch für Geologie und Paläontologie - Abhandlungen, 267:353-362. https://doi.org/10.1127/0077-7749/2013/0317

Makovicky, P.J., Kilbourne, B.M., Sadleir, R.W., and Norell, M.A. 2011. A new basal ornithopod (Dinosauria, Ornithischia) from the Late Cretaceous of Mongolia. Journal of Vertebrate Paleontology, 31:626-640. https://doi.org/10.1080/02724634.2011.557114

Marsh, O.C. 1884. The classification and affinities of dinosaurian reptiles. Nature, 31:68-69.

Marsh, A.D., Smith, M.E., Parker, W.G., Irmis, R.B., and Kligman, B.T. 2020. Skeletal anatomy of Acaenasuchus geoffreyi Long and Murry, 1995 (Archosauria: Pseudosuchia) and its implications for the origin of the aetosaurian carapace. Journal of Vertebrate Paleontology, 40:e1794885. https://doi.org/10.1080/02724634.2020.1794885

Martinez, R.N., Apaldetti, C., Alcober, O.A., Colombi, C.E., Sereno, P.C., Fernandez, E., Malnis, P.S., Correa, G.A., and Abelin, D. 2012. Vertebrate succession in the Ischigualasto Formation. Journal of Vertebrate Paleontology, 32:10-30. https://doi.org/10.1080/02724634.2013.818546

Martz J. 2002. The morphology and ontogeny of Typothorax coccinarum (Archosauria, Stagonolepididae) from the Upper Triassic of the American Southwest. Unpublished Master's thesis, Texas Tech University.

Martz, J.W. and Small, B.J. 2019. Non-dinosaurian dinosauromorphs from the Chinle Formation (Upper Triassic) of the Eagle Basin, northern Colorado: Dromomeron romeri (Lagerpetidae) and a new taxon, Kwanasaurus williamparkeri (Silesauridae). PeerJ, 7:e7551. https://doi.org/10.7717/peerj.7551 
Mastrantonio, B.M., Schultz, C.L., Desojo, J.B., and Garcia, J.B. 2013. The braincase of Prestosuchus chiniquensis (Archosauria: Suchia), p. 425-440. In Nesbitt S.J., Desojo, J.B., Irmis, R.B. (eds.), Anatomy, Phylogeny and Palaeobiology of Early Archosaurs and their Kin. Geological Society of London Special Publication, 379. https://doi.org/10.1144/sp379.10

Mastrantonio, B.M., von Baczko, M.B., Desojo, J.B., and Schultz, C.L. 2019. The skull anatomy and cranial endocast of the pseudosuchid archosaur Prestosuchus chiniquensis from the Triassic of Brazil. Acta Palaeontologica Polonica, 64:171-198. https://doi.org/10.4202/app.00527.2018

Müller, R.T., Langer, M.C., Bronzati, M., Pacheco, C.P., Cabreira, S.F., and Dias-Da-Silva, S. 2018. Early evolution of sauropodomorphs: anatomy and phylogenetic relationships of a remarkably well-preserved dinosaur from the Upper Triassic of southern Brazil. Zoological Journal of the Linnean Society, 184:1187-1248. https://doi.org/10.1093/zoolinnean/zly009

Müller, R.T., von Baczko, M.B.,Desojo, J.B., and Nesbitt, S.J. 2020. The first ornithosuchid from Brazil and its macroevolutionary and phylogenetic implications for Late Triassic faunas in Gondwana. Acta Palaeontologica Polonica, 65(1):1-10.

Nesbitt, S.J. 2007. The anatomy of Effigia okeeffeae (Archosauria, Suchia), theropod-like convergence, and the distribution of related taxa. Bulletin of the American Museum of Natural History, 302:1-84. https://doi.org/10.1206/0003-0090(2007)302[1:TAOEOA]2.0.CO;2

Nesbitt, S.J. 2011. The early evolution of archosaurs: Relationships and the origin of major clades. Bulletin of the American Museum of Natural History, 352:1-292. https://doi.org/10.1206/352.1

Nesbitt, S.J. and Norell, M.A. 2006. Extreme convergence in the body plans of an early suchian (Archosauria) and ornithomimid dinosaurs (Theropoda). Proceedings of the Royal Society B: Biological Sciences, 273:1045-1048. https://doi.org/10.1098/rspb.2005.3426

Nesbitt, S.J. and Butler, R.J. 2013. Redescription of the archosaur Parringtonia gracilis from the Middle Triassic Manda beds of Tanzania, and the antiquity of Erpetosuchidae. Geological Magazine, 150(2):225-238. https://doi.org/10.1017/S0016756812000362

Nesbitt, S.J., Stocker, M.R.., Parker, W.G., Wood, T.A., Sidor, C.A., and Angielczyk, K.D. 2017. The braincase and endocast of Parringtonia gracilis, a Middle Triassic suchian (Archosaur: Pseudosuchia). Journal of Vertebrate Paleontology, 37(sup1):122-141. https://doi.org/10.1080/02724634.2017.1393431

Norell, M.A. and Barta, D.E. 2016. A new specimen of the ornithischian dinosaur Haya griva, cross-Gobi geologic correlation, and the age of The Zos Canyon beds. American Museum Novitates, 3851:1-20. https://doi.org/10.1206/3851.1

Olsen, P.E., Sues, H.D., and Norell, M.A. 2001. First record of Erpetosuchus (Reptilia: Archosauria) from the Late Triassic of North America. Journal of Vertebrate Paleontology, 20:633-636. https://doi.org/10.1671/0272-4634(2000)020[0633:FROERA]2.0.CO;2.

Paes Neto, V.D., Desojo, J.B., Brust, A.C.B., Ribeiro, A.M., Schultz, C.L., and Soares, M.B. 2021a. The first braincase of the basal aetosaur Aetosauroides scagliai (Archosauria: Pseudosuchia) from the Upper Triassic of Brazil. Journal of Vertebrate Paleontology, 41:e1928681. https://doi.org/10.1080/02724634.2021.1928681

Paes Neto, V.D., Desojo, J.B., Brust, A.C.B., Schultz, C.L., Da-Rosa, A.A.S., and Soares, M.B. 2021b. Intraspecific variation in the axial skeleton of Aetosauroides scagliai (Archosauria: Aetosauria) and its implications for the aetosaur diversity of the Late Triassic of Brazil. Anais da Academia Brasileira de Ciências, in press.

Parker, W.G. 2005. A new species of the Late Triassic aetosaur Desmatosuchus (Archosauria: Pseudosuchia). Compte Rendus Paleovol, 4:327-340. https://doi.org/10.1016/j.crpv.2005.03.002

Parker, W.G. 2007. Reassessment of the aetosaur Desmatosuchus chamaensis with a reanalysis of the phylogeny of the Aetosauria (Archosauria: Pseudosuchia). Journal of Systematic Palaeontology, 5:1-28. https://doi.org/10.1017/s1477201906001994

Parker, W.G. 2008. Description of new material of the aetosaur Desmatosuchus spurensis (Archosauria: Suchia) from the Chinle Formation of Arizona and a revision of the genus Desmatosuchus. PaleoBios New Series, 28:28-40.

Parker, W.G. 2016a. Revised phylogenetic analysis of the Aetosauria (Archosauria: Pseudosuchia); assessing the effects of incongruent morphological character sets. PeerJ, 4:e1583. https://doi.org/10.7717/peerj.1583

Parker, W.G. 2016b. Osteology of the Late Triassic aetosaur Scutarx deltatylus (Archosauria: Pseudosuchia). PeerJ, 4:e2411. https://doi.org/10.7717/peerj.2411 
Parker, W.G. 2018a. Redescription of Calyptosuchus (Stagonolepis) wellesi (Archosauria: Pseudosuchia: Aetosauria) from the Late Triassic of the Southwestern United States with a discussion of genera in vertebrate paleontology. PeerJ, 6:e4291. https://doi.org/10.7717/peerj.4291

Parker, W.G. 2018b. Anatomical notes and discussion of the first described aetosaur Stagonolepis robertsoni (Archosauria: Suchia) from the Upper Triassic of Europe, and the use of plesiomorphies in aetosaur biochronology. PeerJ, 6:e5455. https://doi.org/10.7717/peerj.5455

Parker, W.G., Irmis, R.B., Nesbitt, S.J., Martz, J.W., and Browne, L.S. 2005. The Late Triassic pseudosuchian Revueltosaurus callenderi and its implications for the diversity of early ornithischian dinosaurs. Proceedings of the Royal Society B, 272:963-969. https://doi.org/10.1098/rspb.2004.3047

Parrish, J.M. 1994. Cranial osteology of Longosuchus meadei and the phylogeny and distribution of the Aetosauria. Journal of Vertebrate Paleontology, 14:196-209. https://doi.org/10.1080/02724634.1994.10011552

Perez, P.A. and Malabarba, M.C. 2002. A Triassic freshwater fish fauna from the Paraná Basin in southern Brazil. Revista Brasileira de Paleontologia, 4:27-33.

Pretto, F.A., Langer, M.L., and Schultz, C.L. 2019. A new dinosaur (Saurischia: Sauropodomorpha) from the Late Triassic of Brazil provides insights on the evolution of sauropodomorph body plan. Zoological Journal of the Linnean Society, 185:388-416. https://doi.org/10.1093/zoolinnean/zly028

Qvarnström, M., Wernström, J.V., Piechowski, R., Tałanda, M., Ahlberg, P.E., and Niedźwiedzki, G. 2019. Beetle-bearing coprolites possibly reveal the diet of a Late Triassic dinosauriform. Royal Society Open Science, 6:181042. https://doi.org/10.1098/rsos.181042

Reisz, R.R. and Sues, H.D. 2000. Herbivory in late Paleozoic and Triassic terrestrial vertebrates, p. 9-41. In Sues, H.D. (ed.), Evolution of Herbivory in Terrestrial Vertebrates: Perspectives from the Fossil Record. Cambridge University Press, New York.

Reyes, W.A., Parker, W.G., and Marsh, A. 2021. Cranial anatomy and dentition of the aetosaur Typothorax coccinarum (Archosauria: Pseudosuchia) from the Upper Triassic Chinle Formation of Arizona. Journal of Vertebrate Paleontology, 40:e1876080. https://doi.org/10.1080/02724634.2020.1876080.

Roberto-Da-Silva, L.C., Desojo, J.B, Cabreira, S.R.F., Aires, A.S.S., Müller, R.T., Pacheco, C.P., and Dias-Da-Silva, S.R. 2014. A new aetosaur from the Upper Triassic of the Santa Maria Formation, southern Brazil. Zootaxa, 3764:240-278. https://doi.org/10.11646/ zootaxa.3764.3.1

Romer, A.S. 1972. The Chañares (Argentina) Triassic reptile fauna. XIII. An early ornithosuchid pseudosuchian, Gracilisuchus stipanicicorum, gen. et sp. nov. Breviora, 389:1-24.

Sawin, H.J. 1947. The pseudosuchian reptile Typothorax meadei. Journal of Paleontology, 21:201-238.

Schoch, R.R. 2007. Osteology of the small archosaur Aetosaurus from the Upper Triassic of Germany. Neues Jahrbuch für Geologie und Paläontologie, Abhandlungen, 246:1-35. https:// doi.org/10.1127/0077-7749/2007/0246-0001

Schoch, R.R. and Desojo, J.B. 2016. Cranial anatomy of the aetosaur Paratypothorax andressorum Long and Ballew, 1985, from the Upper Triassic of Germany and its bearing on aetosaur phylogeny. Neues Jahrbuch für Geologie und Palaöntologie, Abhandlungen, 279:73-95. https://doi.org/10.1127/njgpa/2016/0542

Schultz, C.L., Martinelli, A.G., Soares, M.B., Pinheiro, F.L., Kerber, L., Horn, B., Pretto, F.A., Müller, R.T. and Melo, T.P. 2020. Triassic faunal successions of the Paraná Basin, southern Brazil. Journal of South American Earth Sciences, 104:102846.

Small, B.J. 2002. Cranial anatomy of Desmatosuchus haplocerus (Reptilia: Archosauria: Stagonolepididae). Zoological Journal of the Linnean Society, 136:97-111. https://doi.org/ 10.1046/j.1096-3642.2002.00028.x

Small, B.J. and Martz, J.W. 2013. A new aetosaur from the Upper Triassic Chinle Formation of the Eagle Basin, Colorado, USA. In Nesbitt, S.J., Desojo, J.B., and Irmis, R.B. (eds.), Anatomy, Phylogeny and Palaeobiology of Early Archosaurs and their Kin. Geological Society, London, Special Publications, 379:393-412. https://doi.org/10.1144/SP379.18

Stocker, M.R., Zhao, L., Nesbitt, S.J., Wu, X., and Li, C. 2017. A short-snouted, Middle Triassic phytosaur and its implications for the morphological evolution and biogeography of Phytosauria. Scientific Reports, 7:46028. https://doi.org/10.1038/srep46028 
Sues, H.D., Olsen, P.E., Carter, J.G., and Scott, D.M. 2003. A new crocodylomorph archosaur from the Upper Triassic of North Carolina. Journal of Vertebrate Paleontology, 23:329-343. https://doi.org/10.1671/0272-4634(2003)023[0329:ancaft]2.0.co;2

Sulej, T. 2010. The skull of an early Late Triassic aetosaur and the evolution of the stagonolepidid archosaurian reptiles. Zoological Journal of the Linnean Society, 158:860881. https://doi.org/10.1111/j.1096-3642.2009.00566.x

Taborda, J.R.A., Cerda, I.A., and Desojo, J.B. 2013. Growth curve of Aetosauroides scagliai Casamiquela 1960 (Pseudosuchia: Aetosauria) inferred from osteoderm histology. In Nesbitt S.J., Desojo, J.B., and Irmis, R.B. (eds.), Anatomy, Phylogeny and Palaeobiology of Early Archosaurs and their Kin. Geological Society, London, Special Publications, 379:413-423. https://doi.org/10.1144/SP379.19

Taborda, J.R.A., Heckert, A.B., and Desojo, J.B. 2015. Intraspecific variation in Aetosauroides scagliai Casamiquela (Archosauria: Aetosauria) from the Upper Triassic of Argentina and Brazil: an example of sexual dimorphism? Ameghiniana, 52:173-187. https://doi.org/10.5710/AMGH.05.01.2015.2824

Trotteyn, M.J. and Ezcurra, M.D. 2014. Osteology of Pseudochampsa ischigualastensis gen. et comb. nov. (Archosauriformes: Proterochampsidae) from the Early Late Triassic Ischigualasto Formation of Northwestern Argentina. PLoS ONE 9(11):e111388. https://doi.org/10.1371/journal.pone.0111388

von Baczko, M.B. and Desojo, J.B. 2016. Cranial anatomy and palaeoneurology of the archosaur Riojasuchus tenuisceps from the Los Colorados Formation, La Rioja, Argentina. PLoS ONE, 11(2):e0148575. https://doi.org/10.1371/journal.pone.0148575

von Baczko, M.B. and Ezcurra, M.D. 2016. Taxonomy of the archosaur Ornithosuchus: reassessing Ornithosuchus woodwardi Newton, 1894 and Dasygnathoides longidens (Huxley 1877). Earth and Environmental Science Transactions of The Royal Society of Edinburgh, 106:199-205. https://doi.org/10.1017/s1755691016000104

von Baczko, M.B., Taborda, J.R.A., and Desojo, J.B. 2018. Paleoneuroanatomy of the aetosaur Neoaetosauroides engaeus (Archosauria: Pseudosuchia) and its paleobiological implications among archosauriforms. PeerJ, 6:e5456. https://doi.org/10.7717/peerj.5456

Walker, A.D. 1961. Triassic reptiles from the Elgin area: Stagonolepis, Dasygnathus and their allies. Philosophical Transactions of the Royal Society of London. Series B, Biological Sciences, 244:103-204. https://doi.org/10.1098/rstb.1961.0007

Walker, A.D. 1964. Triassic reptiles from the Elgin area: Ornithosuchus and the origin of carnosaurs. Philosophical Transactions of the Royal Society of London. Series B, Biological Sciences, 248(744):53-134. https://doi.org/10.1098/rstb.1964.0009

Witmer, J.M. 1997. The evolution of the antorbital cavity of archosaurs: a study in soft-tissue reconstruction in the fossil record with an analysis of the function of pneumaticity. Journal of Vertebrate Paleontology Memoir, 3:1-73. https://doi.org/10.1080/02724634.1997.10011027

Wynd, B.M., Martinez, R.N., Colombi, C., and Alcober, O. 2020. A review of vertebrate beak morphologies in the Triassic; a framework to characterize an enigmatic beak from the Ischigualasto Formation, San Juan, Argentina. Ameghiniana, 57: 370-387. https://doi.org/10.5710/AMGH.13.05.2020.3313

Zacarias, J.D. 1982. Uma nova espécie de tecodonte aetossauro (Aetosauroides subsulcatus, sp. nov.) da Formação Santa Maria, Triássico de Rio Grande do Sul, Brasil. M.S. thesis, Federal University of Rio Grande do Sul, Porto Alegre, Brazil.

Zittel, K.A. 1887-90. Handbuch der Palaeontologie. Abteilung Palaeozoologie. R. Oldenbourg, Munich and Leipzig. 